\title{
EFEITOS DO USO DE SUCEDÂNEO DE LEITE NA ALIMENTACÃO DE LEITÕES LACTENTES E EM RECRIA NO DESEMPENHO E NÍVEL SÉRICO DE IMUNOGLOBULINAS
}

\author{
MARTHA CRISTINA ALVES ESTEVES \\ Engenheira Agrónoma
}

Orientador: Prof. Dr. VALDOMIRO SHIGUERU MIYADA

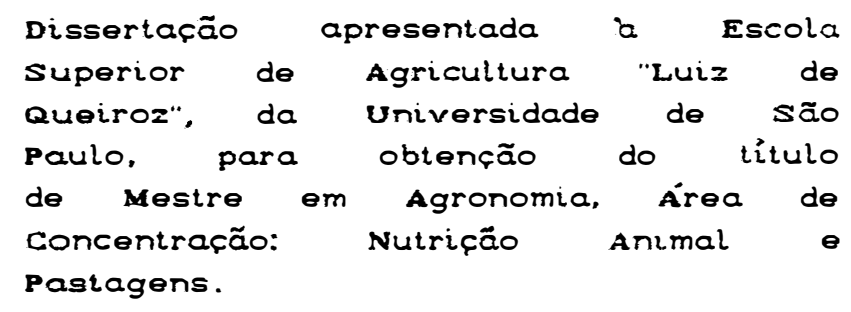

PIRAGICABA

Estado de São Paulo - Brasil

Novembro - 1990 
Ficha catalográfica preparada pela Seção de Livros da Divisão de Biblioteca e Documentaçăo - PCAP/USP

\section{Esteves, Martha Cristina Alves}

E79e Efeitos do uso de sucedâneo de leite na alimentaçăo de leitǒes lactentes e em recria no desempenho e nivel sêrico de imunoglobulinas. Piracicaba, 1990.

135p. ilus.

Diss. (Mestre) - ESALQ

Bibliografia.

1. Imunidade - Sucedâneo do leite - Efeito 2. Leitão - Alimentação 3. Leitão - Desmame precoce 4. Leite - Sucedâneo 5. Sucedâneo do leite na alimentaçăo animal - Efeito I. Escola Superior de Agricultura Luiz de Queiroz, Piracicaba 


\section{EFEITOS DO USO DE SUCEDÂNEO DE LEITE NA ALIMENTAÇ̃̃O DE LEITÕES LACTENTES E EM RECRIA NO DESEMPENHO E NIVEL SÉRICO DE IMUNOGLOBULINAS}

MARTHA CRISTINA ALVES ESTEVES

Aprovada em: 12.12 .1990

Comissão julgadora:

Prof. Dr. Valdomiro Shigueru Miyada ESALQ/USP

Prof. Dr. Raul Machado Neto ESALQ/USP

Prof. Dr. José Fernando Machado Menten ESALQ/USP

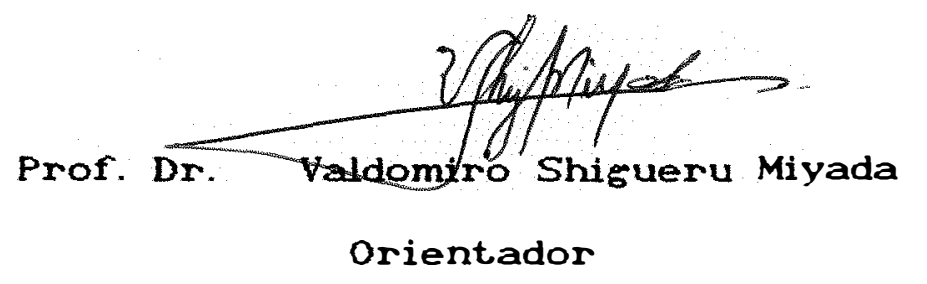


is

minhas avós Belmira e Juileta e meus pais, Dirce e Paulo, pela dedicacão e incentivo 


\section{AGRADECIMENTOS}

Ao Prof. Dr. Valdomiro Shigueru Miyada, pela orientação e amizade;

Ao Prof. Dr. Raul Machado Neto, pela valiosa colaboração e dedicação na condução desta pesquisa;

Ao Dr. José Eduardo Butolo, pelo incentivo a iniciativa desse trabalho e também pela doação do sucedåneo de leite e misturas vitaminicas;

Ao Prof. Dr. Irineu Umberto Packer, pelas sugestőes oferecidas e ao Departamento de Matemática e Estatistica pelo auxilio na utilização do programa na análise estatística dos dados;

A Fazenda Santa Rosa, pelas facilidades colocadas a disposição, que permitiram a realização desse estudo e aos seus funcionários pela eficiente colaboração prestada;

Ao José Ultimio Junqueira Junior, pelo constante apoio e valiosa ajuda na confecção final desse trabalho;

A CAPES, pela bolsa de estudo concedida;

E finalmente, a todos aqueles que de uma forma ou outra colaboraram para a realização desse trabalho. 


\section{SUMARIO}

Página

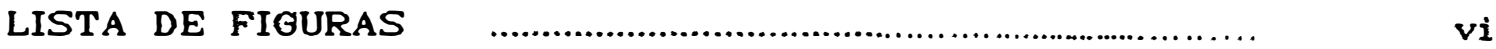

LISTA DE TABELAS

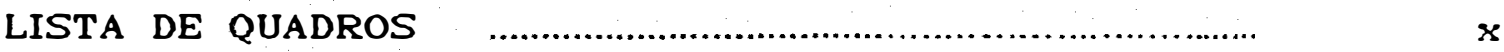

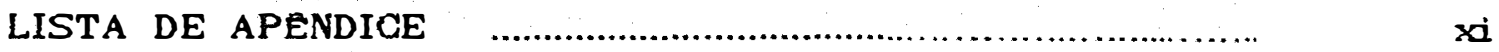

RESUMO

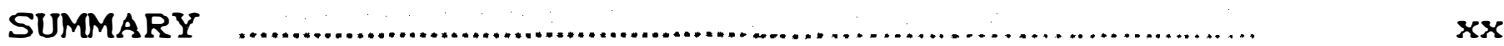

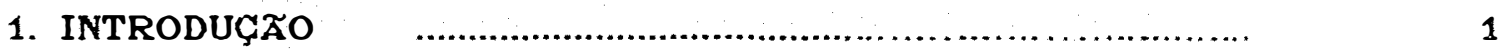

2. REVIST̃O DE LITERATURA

2.1. Griação artificial $\quad$......................................... 4

2.2. Importância do colostro e do leite..................... 8

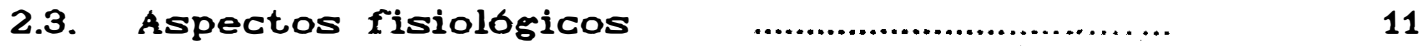

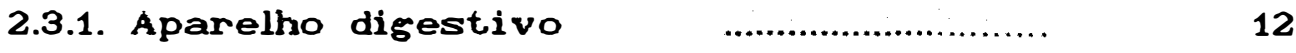

2.3.2. Ocorrência de diarréias $\quad$.....................

2.4. Fontes alternativas para substituição do

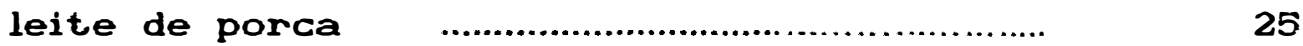

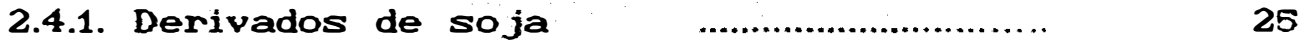

2.4.2. Outros produtos $\quad$..................................

2.4.3. Relação proteina:energia $\quad$............. 29

2.5. Manejo da alimentação $\quad$..................................... 30

2.5.1. Frequiencia da alimentação $\quad$............. 30

2.5.2. Forma da dieta $\quad$.................................. 32

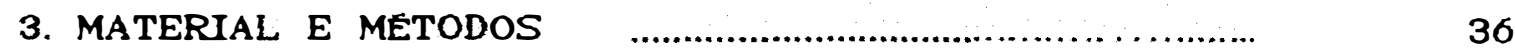


Página

3.1. Local

3.2. Instalaçס̃es

3.3. Animais

3.4. Rações experimentais

3.5. Mane jo das matrizes em lactação e dos leitơes lactentes

3.6. Manejo dos leitơs pós-desmame

3.7. Coleta das amostras de sangue

3.8. Análise das amostras

3.9. Delineamento experimental

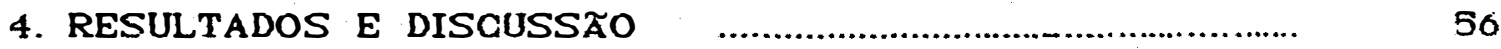

4.1. Caracteristicas de desempenho $\quad$......................... 56

4.1.1. Ganho diário de peso 56

4.1.2. Consumo diário de ração $\quad$........................ 65

4.1.3. Conversão alimentar $\quad$...............................

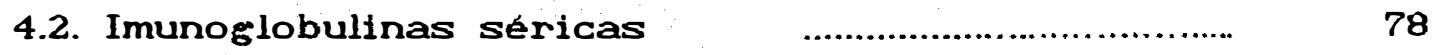

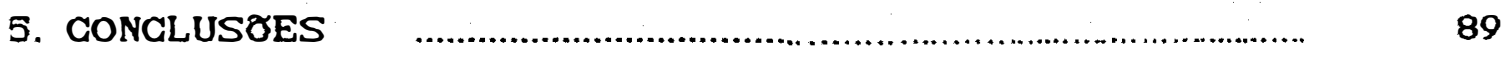

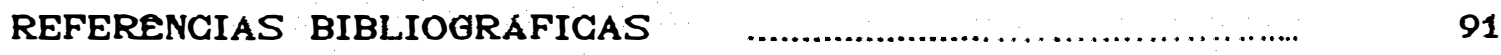

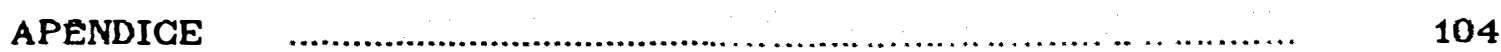


01 Sistema digestivo de um leitão com tres semanas de idade (GADD, 1980) .......................

02 Representação gráfica dos pesos médios, rações fareladas vs peletizadas (A), com sucedáneo de leite vs controle (B), secas vs liquida (C) e $14,4 \%$ vs $9,6 \%$ vs liquida (D)

03 Efeito da peletização no GDP, no periodo total (A) e fases pré-inicial (B) e inicial (C)

04 Efeito das dietas seca cfarelada e peletizada) e liquida no GDP nas quatro semanas da fase pré-inicial, 21-28 (A), 28-35 (B), 35-42 (G) e 42-49 dias (D) .........

05 Efeito do nivel de inclusão de leite nas raçđ̃es pré-iniciais no GDP

06 Efeito da peletização no GDR, no período 
vii.

Figura

Página

total (A), fases pré-inicial (B) e inicial

(G)

07 Efeito das dietas no $C D R$, nas semanas de 28-35 (A) e 35-42 (B) dias

08 Conversão alimentar de leitóes, no periodo total (A) e nas fases pré-inicial (B) e inicial ( $C$ )

09 Flutuação dos niveis de Ig sérica cunidades ZST), em leitชes

10 Regressão polinomial para a flutuação de niveis de Ig, em leitðres de 1-61 dias ..........

11 Regressరoes polinomiais para a flutuação de niveis de Ig sérica, em leitões de 1-28 (A) e de 28-61 dias (B) 
viii.

LISTA DE TABELAS

Tabela

Pagina

01 Composição quimica aproximada e conteudo energético dos ingredientes ......................................

02 Composição dos ingredientes em aminoácidos ..

03

Composição percentual das raçōes

experimentais pré-inicial e inicial

04 Conteudos em nutrientes esperados das rações experimentais pré-inicial e inicial ....

05 Composição das misturas vitaminicas das raçöes pré-inicial e inicial

06 Conteudos em micro minerais das rações préinjcial e inicial

07 Numero de leitões amostrados para a determinação de imunoglobulinas sericas .........

08 Médias de sanho diário de peso ajustadas para o mesmo peso médio inicial referente a 
- 9 Médias de consumo diário de ração ajustadas para o mesmo peso médio inicial refierente a

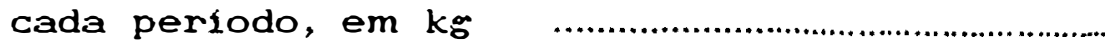

10 Médias de conversão alimentar ajustadas para - mesmo peso médio inicial, referente a cada periodo

11 Médias dos valores de imunoglobulinas séricas, em unidades ZST, dos animais submetidos aos tratamentos T3, T4, T6 e T8 


\section{LISTA DE QUADROS}

Quadro

Pásina

01

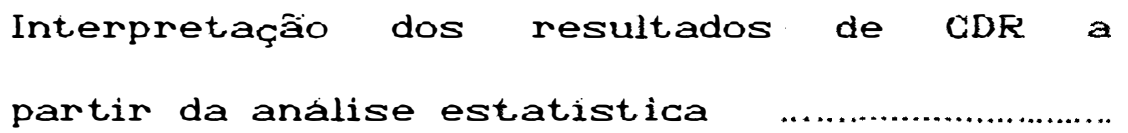

02 Interpretação dos resultados de Ig sérica a partir da análise estatistica, de 1-61 dias ...

03 Interpretaçäo dos resultados de Is serica a partir da análise estatistica, de 1-28 e 28-61 dias 
01 Análises quimicas aproximadas de amostras de rações fase pré-inicial realizadas durante o periodo experimental de rações fase inicial realizadas durante 0 periodo experimental

05 Consumo médio de ração dos animais a partir de 21 dias, em $\mathrm{kg}$

06 Consumo de dieta kquida, dos 21 aos 49 dias, em litros

07 Ganhos diários de peso (GDP, kg) dos animais nas fases pré inicial, inicial e total 
xii.

Apéndice

Página

08 Consumo diário de ração (CDR, kğ) dos animais nas fases pré-inicial, inicial e total

09 Conversão alimentar dos animais nas fases pré-inicial, inicial e total

10 Temperaturas minimas e máximas registradas durante o periodo experimental, $\triangle \mathrm{C}$

11 Consumo diário de ração das matrizes durante o periodo de lactação (CDRM, kg), peso pré-parto (PPP, kg), peso pós parto (PPO, $\mathrm{kg}$ ) e peso no final da lactação (PL, $\mathrm{kg})$

12 Determinaçơes individuais e valores médios de imunoglobulinas séricas (unidades ZST) de leitశes submetidos ao tratamento T3 (14,4\% leite peletizado)

13 Determinaçơes individuais e valores médios de imunoglobulinas séricas (unidades ZST) de leitres submetidos ao tratamento T4 
xiii.

Apéndice

Pagina

$(9,6 \%$ leite peletizado)

118

14 Determinaçôes individuais e valores médios

de imunoglobulinas séricas (unidades ZST)

de leitros submetidos ao tratamento T6

(dieta liquida com ração peletizada)

119

15 Determinaçoes individuais e valores médios de imunoglobulinas séricas (unidades ZST)

de leitores submetidos ao tratamento

T8 (controle leite peletizado)

120

16 Valores médios obtidos a partir das determinaçôs individuais de imunoglobulinas séricas (unidades ZST) de leitð̌s ....

17 Análise de variáncia do ganho diário de peso (GDP) de 21 a 28 dias, com ajuste por covariancia para o peso médio inicial aos 21 dias

18 Análise de variáncia do sanho diário de peso (GDP) de 28 a 35 dias, com ajuste por covariáncia para o peso médio inicial aos 
Análise de variância do sanho diário de peso (GDP) de 42 a 49 dias, com ajuste por covariància para o peso médio inicial aos 42 dias

20 Análise de variància do sanho diário de peso (GDP) de 21 a 49 dias, com ajuste por covariancia para o peso médio inicial aos 21 dias

21 Análise de variância do consumo diário de ração (GDR) de 21 a 28 dias, com ajuste por covariância para o peso médio inicial aos 21 dias

22 Análise de variância do consumo diário de ração (CDR) de 28 a 35 dias, com ajuste por covariância para o peso médio inicial aos 28 dias

23 Análise de variância do consumo diário de raçào (CDR) de 35 a 42 dias, com ajuste por 
covariáncia para o peso médio inicial aos

24 Análise de variáncia do consumo diário de ração (GDR) de 42 a 49 dias, com ajuste por covariáncia para o peso médio inicial aos 42 dias

Análise de variáncia do consumo diário de ração (GDR) de 21 a 49 dias, com ajuste por covariáncia para o peso médio inicial aos 21 dias 130

26 Análise de variáncia do consumo diário de ração (GDR) de 49 a 61 dias, com ajuste por covariáncia para o peso médio inicial aos 49 dias

27 Análise de variáncia do consumo diário de ração (GDR) de 21 a 61 dias, com ajuste por covariancia para o peso médio inicial aos 21 dias 
xvi.

Apêndice

Pagina

de tratamento e periodo de amost.ragem na

flutuação de Io sérica em leitōes, no

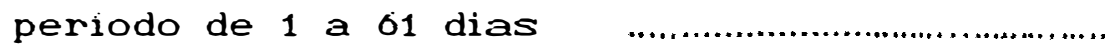

133

29 Análise da variüncia para estudo do efieito

do periodo de amostragem, de 1 a 28 dias,

na flutuação de Iơ sérica em leitões ..............

134

30 Análise da variància para est.udo do efeit.o

do periodo de amostragem, de 28 a 01 dias,

na flutuação de Io serica em leitões …........... 


\title{
EFEITOS DO USO DE SUCEDÂNEO DE LEITE NA ALIMENTACÃO DE LEITÕES LACTENTES E EM RECRIA NO DESEMPENHO E NÍVEL SÉRICO DE IMUNOGLOBULINAS
}

\author{
Autora: MARTHA CRISTINA ALVES ESTEVES \\ Orientador: Prof. Dr. VALDOMIRO SHIGUERU MIYADA
}

RESUMO

o presente trabalho teve por objetivo estudar a influência da adição de diferentes niveis e formas de apresentação cliquida vs seca e rações fareladas-RF vs raçôs peletizadas-RP) de sucedâneo de leite (SL), nas dietas pré-inicial (PI), de 21 a 49 dias, e inicial (I), de 49 a 61 dias sobre o desempenho e nivel sérico de imunoglobulinas de leitôes lactentes e em recria.

Foram utilizadas 32 leitegadas (306 leitðes), provenientes de fêmeas mestiças Landrace e Large White, distribuidas a oito tratamentos em um delineamento em blocos casualizados ( 4 blocos/tratamento). Na fase PI, T1 $14.4 \%$ SL RF; T2 - 9.6\% SL RF; T3 - $14.4 \%$ SL RP; T4 - 9.6\% SL RP; T5 - SL liquido RF; T6 SL liquido RP; T7 - 0\% SL RF e T8 - 0\% SL RP. Na fase inicial, os niveis de $14.4 \%$ e $9.6 \%$ foram reduzidos para $9.6 \%$ e $4.8 \%$, respectivamente, e não houve mais fornecimento de SL na forma liquida nos tratamentos 5 e 6 . 0 SL substituiu parte do farelo de soja 
xviii.

das rações, mantendo os niveis de $21 \%$ de proteina bruta (PB) na fase $P I$ e 19\% de $P B$ na fase $I$. As raçães experimentais foram enriquecidas com premixes vitaminicos e minerais.

Foram realizadas 9 pesagens: ao nascimento, 7,14 , $21,28,35,42,49$ e 61 dias juntamente com o monitoramento do consumo de ração. Nos leitões dos tratamentos com RP também foram feitas amostragens de sangue, retiradas da veia cava anterior, aproximadamente $3-5 \mathrm{ml}$ por animal sendo 7 datas de coleta: $1,2,10,21,28$ (desmame), 35 e 61 dias. As amostras de soro dos leitões foram analisadas através do método ZST ("zinc sulfate turbidity").

Houve aumento do sanho diario de peso (GDP), em kg, na fase PI com o maior nivel (14.4\%) de SL nas rações $(P \leq 0,039)$, sendo 0,248 versus $0,205 \mathrm{~kg}$ nas $R F$ e 0,251 versus $0,233 \mathrm{~kg}$ nas $\mathrm{RP}$. Na semana anterior ao desmame (21-28 dias), os leitశes do T8 apresentaram maior GDP do que os do $T 7 \quad(P \leq 0,035) ; 0,250$ versus $0,156 \mathrm{~kg}$. Embora sem significancia estatistica $(P \leq 0,120), 0$ SL apresentado como suplementação na forma liquida na primeira semana pós-desmame revelou um maior GDP. No entanto, tal fato se reverteu na última semana da fase PI (42-49 dias), quando as dietas com SL na forma em pó apresentaram GDP superior $(P \leq 0,051)$.

Na fase PI, a inclusão de SL, em qualquer nivel ou forma (liquida ou seca) de apresentação, aumentou o consumo 


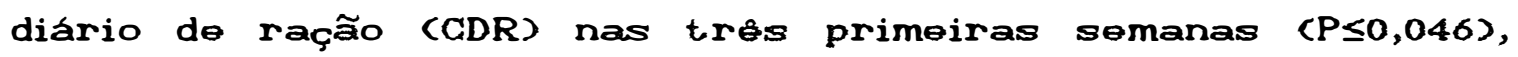
sendo que a forma liquida foi ainda superior à forma seca, quer com 14.4\% ou $9.6 \%$ de $S L \quad(P \leq 0,002)$, o que também foi significativo $(P \leq 0,003)$ se considerada toda a fase $P I$. Houve um aumento $(P \leq 0,042)$ de consumo de ração farelada em relação à peletizada nos tratamentos com dieta liquida na última semana da fase PI.

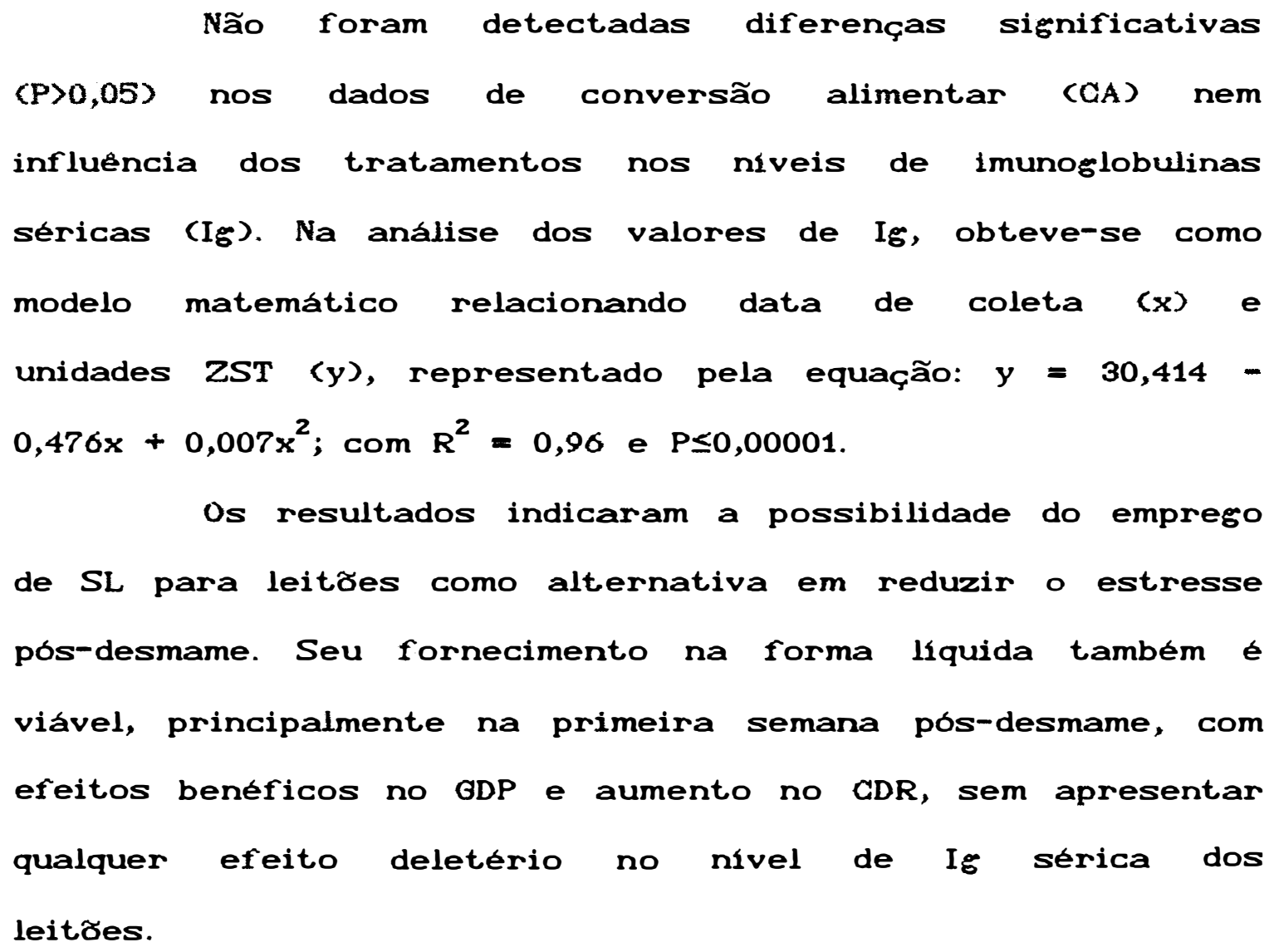


EFFECTS OF FEEDING MILK REPLACER ON THE PERFORMANCE AND IMMUNE RESPONSE OF SUCKLING AND WEANLING PIGS

\author{
Authoress: MARTHA CRISTINA ALVES ESTEVES \\ Adviser: Prof. Dr. VALDOMIRO SHIGUERU MIYADA
}

\title{
SUMMARY
}

\begin{abstract}
The objective of this research was to study the effects of feeding different levels (14.4\% vs $9.6 \%$ ) and physical forms (meal-MD vs pellet-PD) of milk replacer (MR) on the performance and immune response of suckling and weanling pigs, during the pre-starter (PS, 21-49 days of age) and starter (S, 49-61 days of age) period.

Thirty-two crossbred litters cLandrace and Large White) were assigned to one of eight treatments. During the PS were used: $\mathrm{T} 1-14.4 \% \mathrm{MR} M D, \mathrm{~T} 2-9.6 \% \mathrm{MR} M D, \mathrm{~T} 3-14.4 \%$ MR PD, T4 - 9.6\% MR PD, T5 - Liquid MR MD, T6 - Liquid MR PD, T7 - O\% MR MD and T8 - O\% MR PD. During the starter period the levels of $14.4 \%$ and $9.6 \%$ were lowered to $9.6 \%$ and 4.8\%, respectively, and no more liquid $M R$ on treatments T5 and T6 was given.
\end{abstract}

The MR replaced part of soybean meal. All presented experimental diets were formulated to be isonitrogenous with $21 \%$ crude protein (CP) for PS and $19 \%$ 
xxi.

GP for $S$ and supplemented with vitamins and minerals.

Pigs were weighed at birth and weekly at 7,14 , $21,28,35,42,49$ and 61 days of age. From 21 days of age, the feed intake was registered. Blood $(3-5 \mathrm{ml})$ was sampled from anterior vena cava of pigs fed pelleted diets at 1, 2, $10,21,28,35$ and 61 days of age, and the serum was used to determine immunoglobulins (Ig) titers by ZST (zinc sulfate turbidity) method.

Pigs fed $14.4 \%$ MR diet showed higher average daily gain ( $P \leq 0.039$ ) than those fed $9.6 \%$ MR diet during the $P S$ period with 0.248 versus $0.205 \mathrm{~kg}$ in $M D$ form, and 0.251 versus $0.233 \mathrm{~kg}$ in $\mathrm{PD}$ form. During the week before weaning, the pelleted control diet gave better ( $\leq \leq 0.035)$ average daily gain $(0,250 \mathrm{~kg})$ than the meal control diet $(0.156 \mathrm{~kg})$.

During the first week after weaning, the liquid MR diet did not improve significantly (P>0.05) the average daily gain, but pigs fed liquid $M R$ showed a trend $(P \leq 0.12)$ to get higher weight gain than those fed dry MR diets. However, during the last week of PS period, dry MR diets gave better $(P \leq 0.051)$ weight gain than liquid MR diet.

During the first three weeks of PS period, the MR increased $(P \leq 0.046)$ daily feed intake (DFI) and the liquid form of the diet gave higher DFI than the dry form with 14.4 or $9.6 \% M R$. On the other hand, meal diet gave higher $(P \leq 0.042)$ DFI than pelleted diet in the last week (42-49 
xxii.

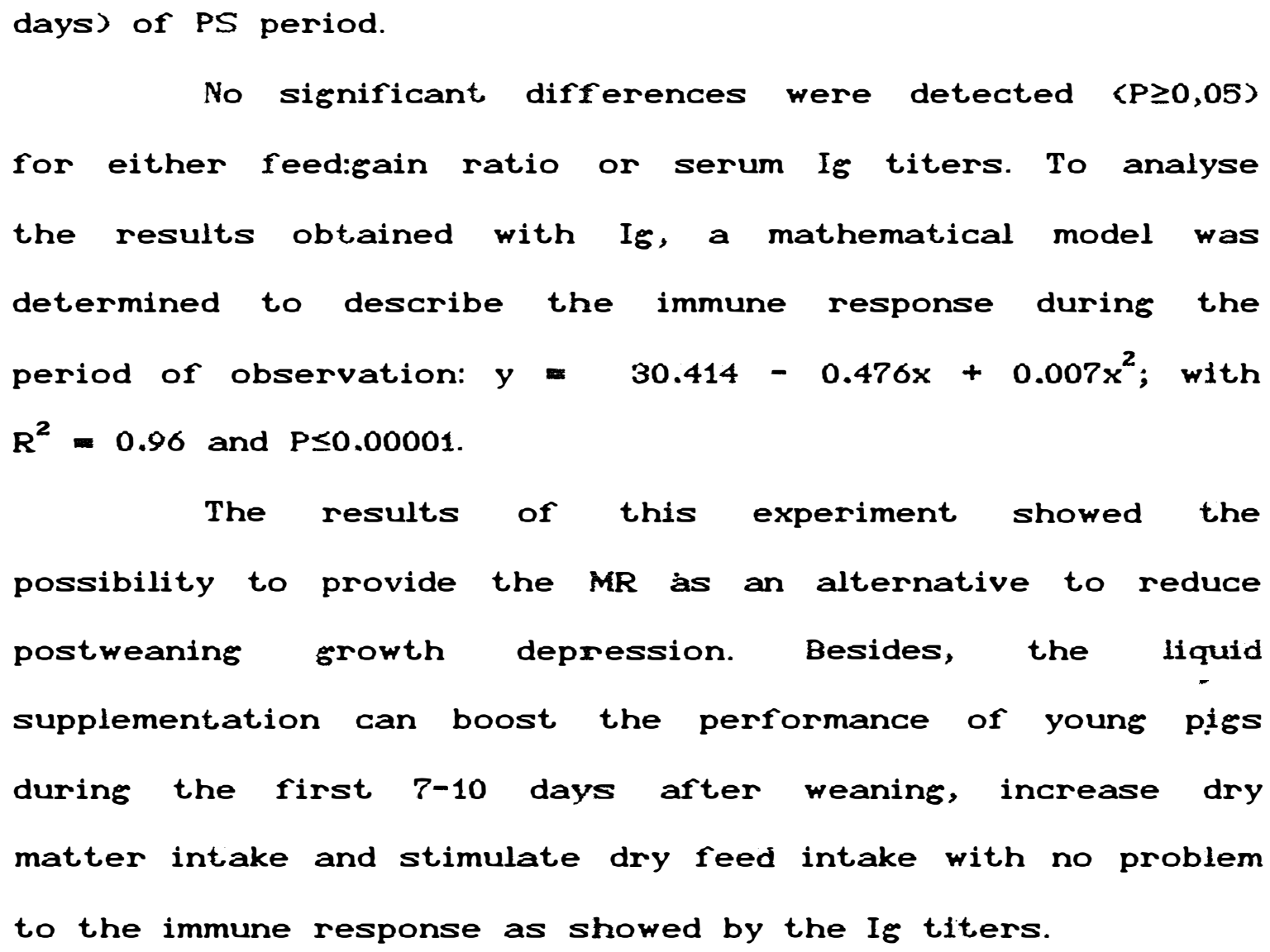




\section{INTRODUCÃ̃O}

o desmame precoce é uma prática bastante dificil
de ser adotada e quanto mais cedo for, menor será a chance
de sobrevivencia e desempenho adequado dos leitås. Tem-se
observado que os leitões recém-desmamados precocemente (14
dias) tém seu crescimento interrompido por diarréia,
desidratação e morte.

Muito se estudou direcionado para uma criação totalmente artificial dos leitões (desmame aos 2 dias), com preocupaçত̃es no sentido da proteção do neonato, através do uso de programas de alimentação e de manejo que limitassem - contato ou mesmo a produção de macromoléculas tóxicas no intestino. o epitélio intestinal deveria ser banhado continuamente por imunoglobulinas enquanto estivesse ávido a absorção e portanto altamente vulnerável.

$$
\text { Constatou-se que os leitres criados }
$$

artificialmente exigem na dieta as proteinas do leite para - máximo desempenho. Pouco se sabe sobre a eficácia relativa dos diferentes sucedáneos de leite como fonte de proteina láctea, tanto em condições de criação artificial 
como convencional. Uma das vantagens da criação artificial reside no fato da similar ou superior taxa de crescimento alcançada em relação aos leitões lactentes. Esse rápido crescimento durante o primeiro mês de vida tem sido obtido com uso de dietas liquidas contendo 125-200 \& matéria seca (MS)/1. Com isso, o potencial de crescimento de leitores desmamados aos 2 dias de idade pode ser plenamente alcançado, considerando que o recém-nascido seria fisicamente incapaz de atingir tão alto consumo de MS de uma ração sólida, como o faz com uma dieta liquida.

No entanto, a técnica de criação artificial não se tornou prática comum nos meios de produção, embora muito tenha se aprendido sobre o leitão neonato e muitas outras dúvidas tivessem surgido.

o desmame entre 14 e 28 dias, bastante comum e já considerado precoce, leva a uma depressão na taxa de ganho que é coincidente com o desmame. Esse periodo pode durar de 7 a 14 dias, quando os leiţ̋es não consomem energia adequada para manutenção do peso corporal, lançando mão de suas reservas de gordura para obtenção de energia. Essa fase é caracterizada por pequeno ou nenhum ganho de peso e baixo consumo de ração, além de estar frequentemente acompanhado de diarréia. Portanto, a depressão pós-desmame é um problema imediato que em muito pode ser beneficiado com os estudos conduzidos em condições de criação artificial. Nesse sentido, mais estudos de nutrição e de 


\begin{abstract}
manejo de leitões jovens devem ser buscados para se obter o melhor desempenho dos animais, considerando que um baixo desempenho logo após o desmame reflete muito mais um manejo ineficiente do que consequéncias inevitáveis do próprio estresse devido ao desmame precoce.
\end{abstract}

Por ocasião do desmame, um complexo conjunto de alterações nutricionais, de ambiente e sociais se instala levando o leitão ao estresse. Do ponto de vista estritamente nutricional, tem-se avaliado sistemas de alimentação que apresentem o alimento na forma liquida como suplemento a dietas pré-iniciais que se oferecem na forma sólida. A idéia básica desse sistema é reduzir o estresse nutricional a um minimo, oferecendo ao leitão uma dieta liquida de alta qualidade nutritiva, junto com a dieta sólida que será consumida posteriormente.

o objetivo central deste estudo foi testar tal
sistema de alimentação, onde procura-se facilitar a mudança
do leite materno para dieta sólida, estimulando a ingestão
de ração e aumentando o consumo de $M S$, além de favorecer a
maturidade do sistema enzimático e digestivo do leitão ao
expó-lo a ingredientes que comumente integram as dietas a
serem consumidas posteriormente, reduzindo assim, a
depressão pós-desmame.




\section{REVISÃO DE LITERATURA}

\subsection{CriaçÃo ARTIFICIAL}

Uma das formas de se avaliar a produtividade das fémeas é através do número de leitőes desmamados/porca/ano e, nesse sentido, a idade de desmame vai influenciar muito na produtividade, que também estará sujeita aos efeitos do intervalo entre partos (NEWPORT, 1977; JUNQUEIRA \& ARAUJO, 1986 e KNUDSON et alii, 1987). A redução do período de lactação, através do desmame precoce, pode aumentar a produtividade das fémeas de 2,05 leitegadas/ano, quando se utiliza um desmame aos 56 dias, para 3,0 leitegadas/ano com - desmame ao nascer e supondo 7 dias de intervalo desmame-cobertura. COALSON \& LECGE (1973b) afirmaram que fémeas não colocadas em lactação podem ser fecundadas cerca de 12 dias pós-parto, possibilitando produzir as 3 leitegadas/ano.

A porcentagem de mortalidade de leitzes na primeira fase de vida representa grande fonte de perdas económicas. Embora com algumas variaçסes entre os autores, 
a maior porcentasem de perda ocorre nos primeiros dias de vida, $20 \%$ nas primeiras 2 semanas para LECGE (1971); 20-25\% do nascimento aos 56 dias, sendo 19-20\% nos primeiros dias sobre os leitões nascidos vivos para NEWPORT (1977) e 20,5\% até oito semanas de idade, sendo $32,5,20,2$ e $16,5 \%$ desse total, para o primeiro, segundo e terceiro dia de vida segundo dia para Kernkamp", citado por TARDIN (1985). A taxa de mortalidade é ainda mais elevada entre os leitros que pesam menos de 1000 \& ao nascimento. Os prequenos leitões, se sobreviverem, vão crescer a taxas menores e são comumente denominados refugos. Sendo a mortalidade muito elevada nos primeiros dias de vida, só se consegue marcante redução no seu indice se o desmame for feito antes dos 2 dias de idade, porque se o desmame for aos 7 dias, a mortalidade se reduziria apenas em aproximadamente $3 \%$ (NEWPORT, 1977).

A preferéncia pelas tetas é estabelecida dentro da leitegada aos 3 dias de idade. Isso já leva a uma seleção natural onde os leitões menores recebem quantidades minimas de nutrientes, bastante inferiores a sua exigencia, devido principalmente a sua ineficiencia quanto à pinocitose do epitélio intestinal. Com isso, também a proteção passiva,

1. KERNKAMP Journal of American Veterinarian Assistance, 146-337, 1965. 
via anticorpos do colostro, é minima e a tendéncia a que os leitð̋es menores tornem-se mais fracos, menos hábeis na competição e sujeitos à morte. Esse comportamento é uma das prováveis causas dos indices de mortalidade e não a falta de potencial de crescimento que esses leitర̃es eventualmente tivessem (LEGGE, 1971).

o sistema de criação artificial poderia aumentar o ganho diário de peso (GDP) já que o crescimento dos leit.óes é limitado pela quantidade de leite da porca. LEWIS et alii (1978) citam o valor de 4,5 \& como sendo a quantidade de leite necessária a ser consumida para cada 1 g de ganho de peso dos leitర̃es. Segundo FERREIRA et alii (1988b) a produção de leite de porca varia de 4,622 a $6,541:$ do 30 ao 240 dia de lactação e de 5,121 a 5,672 e a 5,906 g para porcas de primeira, segunda e terceira parição. Tal produção não seria suficiente nem para atender um GDP minimo de 200 \& mencionado por diversos autores (MENGE \& FROBISH, 1976; JONES et alii, 1977; NEWPORT, 1977 e PETTIGREW \& HARMON, 1977).

A técnica da criação artificial bem manejada também serviria com instrumento de auxilio no controle as enfermidades e possibilidade de criação para leitões órfãos (NEWPORT, 1977).

Com o que já foi dito vêem-se algumas das vantagens obtidas com a remoção dos leitð̃es de suas mães, logo após o nascimento, e submetidos a dietas especialmente 
preparadas, sobre o sistema convencional de criação com a fêmea: interrupção da lactação e encurtamento do ciclo reprodutivo da fémea o que levaria a um aumento de produtividade da fêmea por capacitála a produzir maior número de leitães/ano, redução da mortalidade precoce graças ao controle ambiental, uma melhora na taxa de crescimento pelo fornecimento mais adequado de nutrientes do que o que seria feito pela fêmea e possibilidade de criar leitơes óf fãos.

Embora com todas essas vantagens, ainda hoje, os problemas encontrados envolvem as dificuldades de reprodução das fêmeas cujas leitegadas desmamaram cedo, diarréias nos leitões que podem levar a uma alta mortalidade, falta de conhecimento das exigências nutricionais dos leitơes e da sua fisiologia digestiva (NEWPORT, 1977), falta de equipamentos apropriados para administração de dietas liquidas e alto custo das dietas (RODRIGUEZ \& YOUNG, 1981).

As vantagens prometidas com a criação artificial também são visadas quando se procura fornecer sucedáneos de leite na forma liquida para leitões pós-desmame. Nesse caso, um objetivo adicional é o de incrementar o desempenho dos animais nos primeiros 7-10 dias após o desmame, onde se verifica com frequência uma estabilização ou mesmo redução no seu crescimento conhecida como depressão pós-desmame (LEIBBRANDT \& KEMP, 1987). 


\title{
2.2. IMPORTÂNCIA DO COLOSTRO E DO LEITE
}

\begin{abstract}
Diversos autores vêm, sistematicamente, se preocupando em determinar as exigências nutricionais dos leitões nas primeiras fases da vida (SCHNEIDER \& SARETT, 1969; LEGCE \& COALSON, 1976; JONES et alii, 1977; NEWPORT, 1977; SHERRY et alii, 1978 e RODRIGUEZ \& YOUNG, 19813.

Desde há muito tempo se sabe que o le1tão recémnascido é totalmente desprovido de imunoglobulinas (Ig), CCATRON et alii, 1953; ASPLUND et alii, 1962; BOURNE, 1973; COALSON \& LEGGE, 1973b; WILSON, 1974 e LEGGE, 1975). O neonato é dependente do colostro, única fonte de anticorpos séricos, obtido nas primeiras horas de vida, e tambem do leite materno para presença continua de anticorpos.

Embora leitões livres de colostro e que não tenham recebido anticorpos, consequientemente desprovidos de $I_{f}$ e livres de patógenos sejam animais de valor único para investigações biológicas, seu desenvolvimento é bastante dificultado. Tentativas com incubadoras artificiais CVARLEY et alii, 1985) ou desmame com 1-2 dias com injeção de $\gamma$-globulina porcina (LEGGE \& COALSON, 1976) têm sido avaliadas.
\end{abstract}

o fornecimento de colostro é critico para a sobrevivência do leitão neonato. Alguns autores (BROWN et alii, 1961; MILLER et alii, 1962) citam que os anticorpos são adquiridos nas primeiras 24-36 horas de vida, embora a 
absorção após 24 horas seja insignificante. HAYE \& KORNEGAY (1979) afirmam que a imunidade passiva derivada do colostro atinge o máximo 24-36 horas pós-parto e, a partir daí, ela diminui logaritmicamente. MENGE \& FROBISH (1976) citam 12 horas de mamada e COALSON \& LEGGE (1973a) citam que as primeiras 2 horas de mamada $(40-60 \mathrm{ml})$ de colostro é o tempo necessário para que o neonato adquira adequada proteção. Durante esse cempo, quantidades suficientes de colostro são consumidas para que haja alteração na fração $\beta_{2}-\gamma$-globulina, no soro do leitão, de $3 \%$ para $30-40 \%$ da proteina total do soro. Deve-se, no entanto, certificar que todos os leitơes tenham igual acesso ao primeiro colostro. Esta imunidade humoral adquirida via colostro é suriciente para proteger leitóes criados artificialmente com dispensador automático, conforme mostra o trabalho de COALSON \& LECGE (1973b). Estes autores observaram que, sob as condições de criação comercial, 12 horas de lactação foram suficientes para garantir a ingestão de grandes quantidades de imunoglobulina e o subsequente desenvolvimento do animal. No caso de baixas condições sanitárias (acúmulo de fezes e ar saturado), observou-se uma forte diarréia nos leitôes que mamaram apenas por 12 horas, diferentemente daqueles que mamaram por 36 horas, embora ambos tivessem igual quantidade de If circulante, o epitélio intestinal desses últimos foi exposto a If por mais tempo. 
Conclui-se que, embora existam variaçãos nas recomendaçớs do tempo minimo de mamada, o colostro é importante para que o leitão receba proteção contra doenças sistêmicas nos primeiros 10-14 dias, enquanto que a proteção a doenças entéricas é conseguida pela ingestão continua de anticorpos do leite. A partir dos 10 dias de idade, o leitão começa a produzir seus próprios anticorpos. Cada um desses mecanismos de imunidade é idealmerite adaptado para sua função no controle imunológico de doenças infecciosas e cada uma delas é essencial para o sucesso na criação dos leitชes (WILSON, 1974).

BLEGHA et alii (1983) afirmaram que a idade de desmame, quando inferior a 5 semanas, poderia causar alteraçôs detrimentais à reação celular imune. Essas alteraçőes poderiam alterar a susceptibilidade às doenças. KELLEY \& EASTER (1987) mostraram como a dieta pode afetar o "status" imunológico. Em contrapartida, GRENSHAW et alii (1986) relataram que a idade de desmame, a temperatura e a dieta não influem no "status" imunológico do leitão.

Quando os leitชes são desmamados aos 14-21 dias de idade, as raçбes com ingredientes alternativos, baseadas em cereais e proteinas de boa qualidade, principalmente de origem vegetal são satisfatórias. No entanto, é conveniente a inclusão de pequenas quantidades de leite em pó desnatado para melhorar a aceitabilidade e conseguir uma ingestão suficiente de alimentos. NEWPORT (1977) cita que as 
atividades da pepsina no estómaro e da tripaine quimot.ripsina pancreáticas são muito baixas ao nascimento e não aumentam consideravelmente até terem transcorridas várias semanas. Os baixos niveis de enzimas proteoliticas podem impedir a digestão das proteinas não lácteas. Não há dúvidas de que os leitores criados artificialmente podem necessitar de orandes quantidades de leite desnatado em pó ou outros produtos lácteos na ração, devido à imaturidade do seu sistema digestivo, principalmente nas primeiras três semanas de vida (LECGE \& COALSON, 1976; JONES et alii, 1977; NEWPORT, 1977; PETTIGREW \& HARMON, 1977; EFIRD et alii, 1982 e LANDELL et alii, 1985b).

SHERRY et alii (1978), testando o farelo de soja, leite desnatado e soro seco em diversas proporçôs na dieta de leitões de 1-21 dias, observaram que dietas iniciais, com menos de $25 \%$ de proteinas lácteas, proporcionaram um desempenho reduzido não sỏ no periodo experimental (1-21 dias) como tambem no periodo subsequente late 56 ou 63 dias).

\subsection{AsPECTOS FISIOLÓGICOS}

Os estudos sobre os sucedáneos de leite, encontrados na literatura, mostram que o sucesso da criação artificial de leitôs tem sido conseguido com dietas que diferem largamente em suas composiçôs. É bastante 
improvável que muitas dessas dietas usadas sejam perfeitamente adaptadas para atender todas as exigências do leitão muito jovem. Se o fossem, a criação artificial de leitơes já teria sido absorvida pelo sistema de produção suina. Existem também preocupaçơes com as limitaçơes práticas da criação artificial, como alto custo do alimento e inabilidade dos leitơes com menos de 5 dias consumirem dieta sólida.

Para se formular dietas eficientes para sucesso do desmame precoce é importante conhecer o máximo possivel as exigências do leitão e os aspectos fisiológicos do seu sistema digestivo, incluindo toda e qualquer alteração na capacidade digestiva que pode ocorrer com a idade e com o desmame. O periodo mais importante é do nascimento as 3 semanas de idade, quando o desenvolvimento da capacidade digestiva do leitão jovem sofre as mais profundas alteraçơes, sendo elas mais evidentes entre 14 e 21 dias de idade (EFIRD et alii, 1982).

\subsubsection{Aparelho Digestivo}

As funçỡes primárias do trato gastro intestinal (TGI) e de seus órgãos acessórios são a digestão e a absorção, em velocidade adequada, de nutrientes essenciais para os processos metabólicos do animal. Além disso, a mucosa deve selecionar, evitando a absorção de substâncias 
que poderiam ser tóxicas. Us aspectos particulares da digestão devem ser avaliados no periodo pós-natal e na época de desmame, que são periodos criticos para certas espécies, especialmente a suina. Além disso, a prática do desmame precoce, comum nos modernos programas de produção intensiva de suinos introduz estresses adicionais à função digestiva.

o sistema digestivo de um leitão, desmamado aos 21 dias com $5 \mathrm{~kg}$ de peso vivo, pode ser visualizado na figura abaixo.

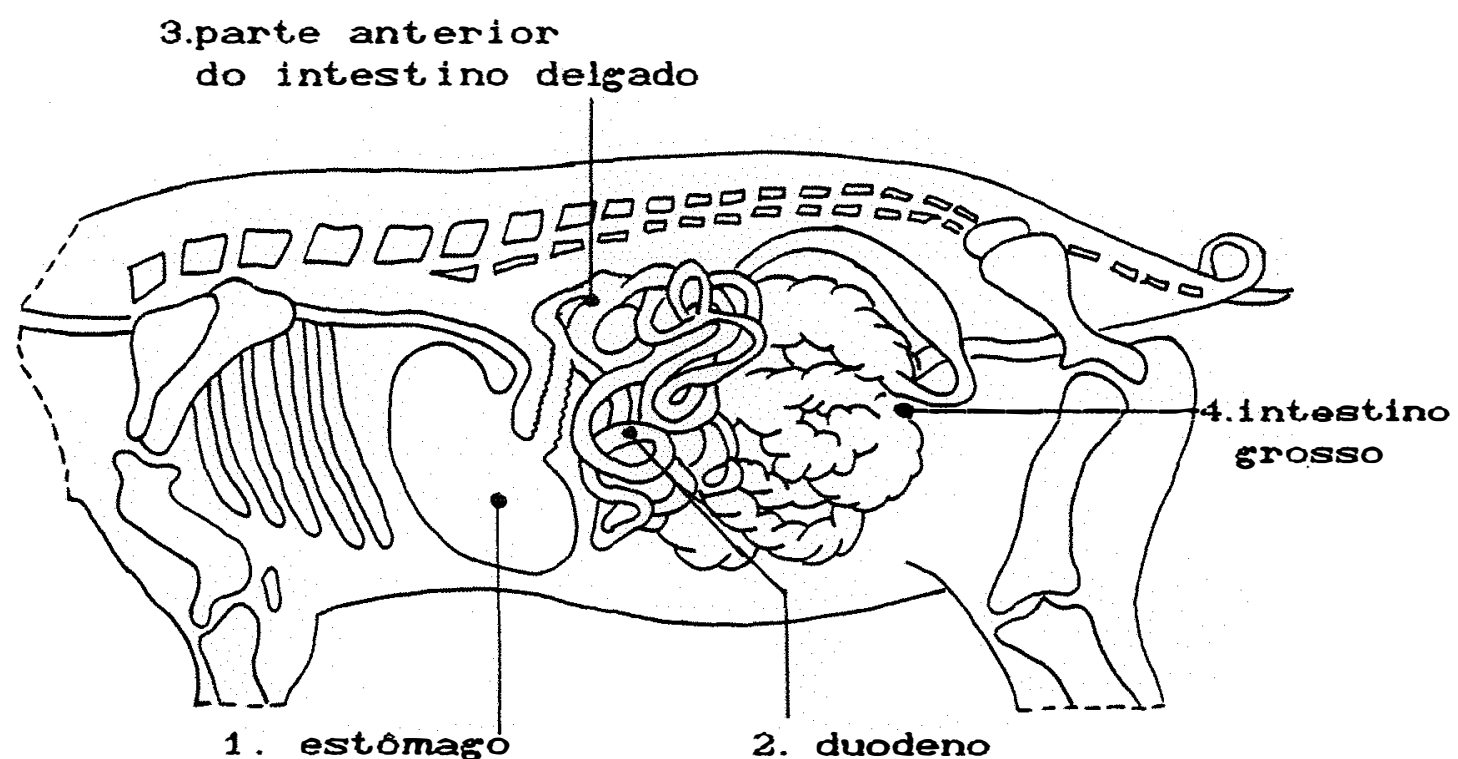

Figura 01 - Sistema difestivo de um leitão com trés semanas
de idade (GADD, 1986)

o estómago (1) com capacidade para 0,2 litros não se expande. O alimento permanece ar cerca de 45 minutos para ser misturado com o ácido cloridrico, que vai atacar 
microrganismos prejudiciais, e com enzimas, que vão iniciar a disestão protéica. Nessa fase, a voracidade no consumo de alimentos não permite tempo suficiente para que tais fatos ocorram. No duodeno (2) com capacidade para quase 0,2 litros, haverá neutralização do conteúdo gástrico com auxilio das células da mucosa e o bolo alimentar passa a ser envolvido por enzimas lipoliticas de forma que a gordura alimentar é preparada para posterior digestão e absorção na porção seguinte do trato. Havendo muito alimento proveniente do estómago, a digesta continuará seu curso pelo TGI apenas parcialmente preparada. A porção superior do intestino delgado (ID-3) é bastante longa, com imensa área superficial devido a milhares de milhões de pequenas vilosidades que absorvem os nutrientes. Essa parte do trato não é capaz de lidar com alimento pobremente processado. Finalmente, o intestino grosso $(I G-4\rangle$ se responsabiliza pela absorção de água e dos ácidos graxos volateis produzidos pela fermentação da fibra e não está envolvido de forma alsuma com a depressão pós-desmame. 0 problema surge quando o leitão é desmamado. Ao desmame, é prática comum a alteração abrupta que os leitões sofrem de seu regime de alimentação liquida, quase de hora em hora, para um regime alimentar de ração seca e água. Além dessa severa mudança alimentar, o animal se depara com outras situações potenciais de estresse, tais como, a separação da mãe, mudança de ambiente, quebra da ordem social e 
densidade, além da idade e peso dos leitães que também vão influenciar no aparecimento da conhecida depressão pós-desmame (LECGE et alii, 1979). Interrompendo-se sua inğestăo regular e não comendo logo em seguida ao desmame, - leitão fica faminto passando, então, a ingerir alimentos com voracidade. O alimento em excesso vai levar a bloqueio digestivo e prejuizos intestinais. Com isso 0 animal sofre um colapso no seu crescimento num estágio vital do seu desenvolvimento, o inicio da fase de aceleração do crescimento muscular, o que é transferido para a fase de crescimento-terminação $(30-40 \mathrm{~kg}$ para abate) e cada dia perdido nessa fase pode representar 2-3 dias de atraso na fase de terminação (GADD, 1986).

o valor de pH gástrico em leitðes é bastante variável entre os diversos autores; 2,1-4,26 (BRAUDE et alii, 1970; MANNERS, 1970; CAMPBELL et alii, 1971; BRAUDE $\varepsilon$ NEWPORT, 1973; PETTIGREW et alii, 1977a; DECUYPERE et alii, 1978 e EFIRD et alii, 1982). O mesmo ocorre para os valores de pH em outras porçбes do TGI. No duodeno, por exemplo, os valores encontrados são 6,5-7,0 CMANNERS, 1970 e GAMPBELL et alii, 1971).

Essa grande variação se deve a alguns fatores como: tipo de medição feita; tipo de dieta, principalmente quanto ao seu teor em proteina (MANNERS, 1970); o método de alimentação, se liquida, seca ou convencionalmente com a mãe (MANNERS, 1970 e EFIRD et alii, 1982); tratamento que 
possa ter sofrido o leite previamente ao seu fornecimento aos animais (BRAUDE et alii, 1971); e movimentos do conteúdo do TGI de uma parte para outra, durante as manipulações cirúrgicas, no sacrifício do animal. Assim, os valores coletados de $\mathrm{pH}$ podem não estar refletindo as condiçōes in vivo (PETTIGREW et alii, 1977a).

Comum em todos os trabalhos é a tendência dos valores de $\mathrm{pH}$ ao longo do TGI, un valor baixo encontrado no conteúdo gástrico, que se reduz com a idade e tem seu valor mais baixo entre 60-90 minutos após a alimentação, uma elevação do pH no ID e novamente uma leve redução de pH nas diferentes porçôes do IG. Há também concordancia que os valores de $\mathrm{pH}$ para leitơes criados artificialmente são normalmente mais altos do que para leitões lactentes.

Segundo DECUYPERE et alii (1978), o desmame precoce não afeta a secreção gástrica de ácido, que se inicia desde 5-6 dias de idade até 10 dias de idade e não há evolução dependente da idade dessa capacidade secretória até 28-35 dias. Segundo Cranwell ${ }^{2}$ citado por EFIRD et alii (1982), o inicio dessa secreção pode ser influenciado pela idade e limpeza do ambiente. A acidez do conteúdo estomacal * afetada tanto pelos lons hidrogenio da secreção das

2. CRANWELL, P.D. Gastric acid secretion in newly born piglets. Research Veterinary Science, 16:105, 1974. 
glándulas gástricas como pela produção de ácidos orgánicos, devido à fermentação bacteriana, onde se destaca o ácido lático. As diferenças na capacidade tampão das dietas e do leite da fêmea também contribuem para as diferenças de $\mathrm{pH}$ sástrico.

Embora exista pouco conhecimento sobre nutrição do leitão desmamado, há muito sabe-se da imaturidade do seu sistema enzimático digestivo CHARTMAN et alii, 1961; SCHNEIDER \& SARETT, 1969; NEWPORT, 1977; JUNQUEIRA \& ARAUJO, 1986).

o desenvolvimento e as mudanças na secreção de enzimas digestivas são de importante significado prático para as formulações de dietas substitutivas do leite. A maioria das mudanças quimicas que ocorre nos processos digestivos é atribuida à ação das enzimas. Uma considerável variedade de enzimas está presente nas secreçôes produzidas pelas várias glândulas associadas ao TGI, nas células perdidas pela mucosa intestinal e dentro da própria mucosa intestinal. A atividade do espectro enzimático sobre o alimento não é estática. Para a maioria das enzimas as atividades aumentam ou diminuem conforme a concentração do substrato disponivel, e também são dependentes do $\mathrm{pH}$ (ARGENZIO, 1988).

A insuficiência de amilase salivar e pancreatica em suinos jovens faz com que o leitão desmamado precocemente não tolere grandes quantidades de amido 
(NEWPORT, 1977).

E sabido e documentado por diversos autores (DECUYPERE et alii, 1978 e SWENSON, 1988) a baixa atividade proteolitica da mucosa gástrica ao nascimento e durante as 2 primeiras semanas de vida dos leitões.

Segundo MANNERS (1970), a atividade proteolitica da secreção pancreática é alta em leitões jovens (20 dias), mas se reduz consideravelmente com a idade, embora não seja unånime entre os autores.

De qualquer forma, a atividade da enzima proteolitica secretada pelas mucosas do estómago e do páncreas, parece não ser afetada pelo tratamento sofrido pelo leite, nivel ou frequência de ingestão cBRAUDE et alii, 1971). Os leitões que consomem uma dieta sólida apresentam aumentos mais rápidos na atividade proteolitica, talvez devido a influéncias hormonais, como estimulo na liberação de gastrina pela presença de coágulo de caseína no estómago.

Outro fator é o próprio desmame que resulta num aumento da secreção das enzimas proteoliticas tripsina e quimotripsina no lúmen intestinal. Contudo, a atividade dessas enzimas, a nivel pancreatico, tende a ser menor nos leitôes com dietas artificiais (EFIRD et alii, 1982).

Após a ação das enzimas pancreáticas, os produtos da digestão, proporcionada pela amilase e proteases no lúmen do intestino, devem ser ainda hidrolisados, para que 
possam ser transportados para as células epiteliais. 'As enzimas para tal atividade estão presentes na camada ciliada da membrana epitelial da célula. São 6 diferentes carboidrases na camada ciliada do ID do suino clactase, trealase, isomaltase, sacarase e 2 maltases.

Segundo GAMPBELL et alii (1971), a atividade especifica da lactase é alta nos primeiros $2-3$ dias de vida e depois declina. A atividade da lactase que diminui normalmente com a idade parece ser inibida pelo desmame (MILLER et alii, 1986 e RATCLIFFE et alii, 1989). Já as atividades da sacarase e da maltase. são baixas ao nascimento, aumentam com idade e também são afetadas pelo desmame, que reduz suas atividades. Segundo RATCLIFFE et alii (1989), a atividade das dissacaridases nos tecidos de leitశes gnotobióticos cleitชes que não recebem colostro ao nascimento e são mantidos em auséncia virtual de bactérias antigénicas que ameacem o sistema imunológico do TGI é mais alta do que a registrada em animais da mesma idade não gnotobióticos.

Quanto à invertase, sua atividade especifica foi desprezivel em leitőes de 18-22 horas. As atividades especificas das fosfatases alcalina e ácida são altas às 18-22 horas pós nascimento e declinam rapidamente permanecendo relativamente baixa ate 14 dias. A atividade da fosfatase alcalina não foi afetada pela idade ou desmame quando medida no intestino de leitres com 4-6 semanas de 
idade. A atividade da enzima aminopeptidase parece ser afetada pela criação artificial. Em leitões lactentes, a atividade dessa enzima se eleva marcadamente nos primeiros 6 dias de vida e depois sofre uma redução. Essa elevação absolutamente não ocorre em leitões oriundos de histerectomia; ao contrário, a atividade chega a cair. abaixo dos valores iniciais e permanece baixa com apenas alguma flutuação até os 11 dias (CAMPBELL et alii, 1971).

Vê-se então que a atividade enzimática pode ser influenciads $\mathrm{mor}$ diversos fatores: $\mathrm{pH}$, presença de alimento sólido, influéncias hormonais, ocasião do desmame e tipo. de dieta (GRANT et alii, 1987). Quanto aos problemas induzidos pelo desmame na função intestinal, parece ser causado mais por alterações $n$ estrutura intestinal e perda especifica de enzimas digestivas do que qualquer alteração na função absortiva (MILLER et alii, 1986).

Há necessidade de se conhecer certas propriedades fisiológicas especificas do sucedáneo, bem como o seu conteúdo em nutrientes, especialmente daqueles fornecidos nos primeiros 21-28 dias após o nascimento. Há indicação de que o fator mais importante é a capacidade de coagulação do sucedáneo. Durante a coagulação, a proteina dietética é separada em uma fração insolúvel, que tem tempo de retenção gástrica relativamente longo e uma fração de proteinas solúveis do soro, que deixam o estómago rapidamente. Quando não existe coagulação de proteinas, elas passam rapidamente 
ao ID e, como não há enzimas suficientes para uma rápida digestão, boa parte dessas proteinas passam intactas ao IG onde săo atacadas por bactérias ocasionando, inicialmente, uma diarréia alimentar que passa a ser infecciosa CLANDELL et alii, 1985a). Além disso, ambas as frações protéicas parecem ter certas propriedades fisiológicas especificas além do seu conteúdo em nutrientes, assim como a presença de proteinas do leite inalteracio parece essencial para otima performance. Ao que parece, a alteração na proporção relativa dessas frações solúvel e insolúvel, na presença de proteina láctea intacta, afeta a fisiologia digestiva com consequencia na performance do animal CDEGUYPERE et alii, 1981).

Portanto, a formação do coágulo da dieta no estómago deve estar relacionada com a taxa de esvaziamento para o ID, de maneira a manter a alta eficiencia de absorção dos nutrientes. Segundo BRAUDE et alii (1970), encontra-se pouca digestão protéica no estómago, onde a digesta está continuamente presente e provavelmente incorporada no coágulo formado pelo leite consumido em refeiçōes regulares, enquanto que a proteólise no ID se processa rapidamente sendo que a taxa de fluxo da digesta é consideravelmente mais baixa na porção distal do que nas regiơes proximais do ID.

Segundo BRAUDE et alii (1971), o tratamento sofrido pelo leite parece afetar a aparencia física do 
coágulo gástrico e o periodo de inicio de esvaziamento gástrico. Se um leite com pequena capacidade de coagulação é dado com alto nível de consumo, induz-se a maior taxa de esvaziamento gástrico para ID para que a digestão possa ser eficientemente completada, só que o material não digerido no ID vai predispor o animal a infecção por cepas de bactérias patogénicas.

Outro fator a influenciar a formação do coágulo gástrico é a frequiencia de alimentação. Segundo PETTIGREW et alii (1977b), a formação de coágulos estomacais grandes e firmes ocorreram em leitzes que foram alimentados 3 vezes/dia, mas leitðes que jejuaram por 12 horas, após terem tido consumo ad libitum, mostraram pouca ou nenhuma formação de coágulo. Aparentemente o coágulo havia sido liquefeito.

A função do coágulo na fisiologia digestiva do suino ainda não é bem compreendida. O que se sabe é que formação do coágulo consistente é necessário para desempenhar sua função de armazenamento de proteina e gordura a ser liberada lentamente ao ID, evitando assim uma sobrecarga e um super crescimento bacteriano. Existem também indicaçôes de que a presença do coágulo duro no estómago estimula as atividades enzimáticas proteoliticas, tanto gástrica como pancreática (DECUYPERE et alii, 1981 ). Com a idade, esse coágulo torna-se "macio" e novamente disperso como era em leitðes muito jovens (MANNERS, 1970). 
Entre diferentes fontes proteicas, a proteina láctea se destaca quanto ao seu processo de coagulação. Sua mais lenta taxa de passagem para o intestino, faz com que represente a melhor alternativa e com maior rendimento e retenção de $\mathrm{N}$ (NEWPORT, 1977). No caso de leitões que recebem leite de vaca em pó, forma-se um coágulo de caseina firme no estómago, ao contrário do que ocorre com o relativamente macio precipitado de caseina obtido do leite de porca. Essa diferença de consistência de coágulo é comum entre leitơes lactentes e leitões criados artificialmente (DECUYPERE et alii, 1978). Esses efeitos benéficos do coágulo apropriado parecem estar limitados às primeiras 2-3 semanas de vida do animal.

A formação do coágulo deve ser importante também em dietas liquidas, onde grandes quantidades de alimento são ingeridas de uma só vez. Contudo, quando são dietas secas, os leitôes têm numerosas pequenas refeiçôes/dia (parecido com o que ocorre na lactação) e o fluxo de nutrienties para o ID é praticamente continuo. Sob tais circunstancias, pode-se especular que seria vantajoso simular as condiçôes naturais e fornecer um sucedảneo de leite que produzisse grande quantidade de proteina da fração solúvel produzida pelo coágulo.

\subsubsection{OCORRÊnCIA dE DIARRÉIAS}


E importante salientar que, embora tenha sido srande a expectativa em torno de uma criação artificial ou de um desmame precoce bem sucedido, o que se consesuiu, na prática, foi a frustração da idéia devido à diarréia, desidratação e morte (LECGE, 1975). A alta taxa de mortalidade ocorre principalmente entre 3-4 semanas de idade (MILLER et alii, 1986). Essa mortalidade pode atingir até $20 \%$ e suas causas são incertas, mas podem ser devido a fatores microbianos ou nutricionais, ingredientes inapropriados, combinados com pobre manejo do desmame precoce e devido à má absorção de Is na criação artificial (DECUYPERE et alii, 1978). A diarréia quase sempre é acompanhada de éxtase gástrica, o que cria um meio mais favorável para prolifferação de bactérias (NEWPORT, 1977). No neonato, a absorção não discriminada é o principal fator da vulnerabilidade do trato (LECGE, 1975).

Por ocasião do desmame, a mucosa intestinal do leitão volta a ser ineficiente na absorção de eletrólitos e água. Com isso, há fornecimento de fluido para o colo, levando-o a agir como reservatório para digestão microbiana (SWENSON, 1988).

Além disso, diversos outros fatores podem estar influenciando a ocorréncia de diarréia, como a composição da dieta (PETTIGREW et alii, 1977a), a forma de apresentação da dieta CMANNERS, 1970; BRAUDE \& NEWPORT, 1977 e PETTIGREW et alii, 1977b) e a condição de higiene do 
ambiente (MANNERS, 1970 e RATCLIFFE et alii, 1989).

\title{
2.4. Fontes alternativas para Substituicã̃o do Leite de PORCA
}

\begin{abstract}
As dietas normalmente usadas para maximizar o crescimento de leitð̃es, criados artificialmente do nascimento às 2 semanas de idade, contêm sólidos de leite não gordurosos. Para o máximo ganho, a proteina láctea deve constituir no minimo $25 \%$ das calorias totais da dieta (cerca de $32 \%$ da MS). Só que o custo dessas dietas, após 14 dias, torna-se extremamente elevado, devido ao aumento do consumo dos animais; dal a procura por fontes protéicas alternativas para esses leitães (JONES et alii, 1977).
\end{abstract}

\subsubsection{DeRIVADOS DE SOJA}

Já na década de 60, SCHNEIDER \& SARETT (1969), comparavam o desempenho de leitões submetidos a isolado protéico de soja suplementado com a metionina versus a proteina do leite bovino. Concluiram que o isolado protéico era bem utilizado e sua qualidade protéica, quando suplementado com metionina, era cerca de $85 \%$ em relação à proteina do leite.

JONES et alii (1977) utilizaram o farelo de soja para determinar a quantidade de proteina exigida para 
máximo crescimento. Observaram que a proteina derivada do farelo de soja era capaz de manter o crescimento de leitões até 21 dias tão bem quanto uma dieta com sólidos não gordurosos do leite, sendo que as necessidades protéicas eram atendidas com dietas onde a proteina constituia até $11 \%$ das calorias totais da dieta.

ZAMORA \& VEUM (1978) concluiram que o desempenho de leitroes neonatais foi reduzido com o aumento (de $25 \%$ para 52\%) do nivel dietético do farelo de soja. Embora o nivel dietético mais elevado do farelo de soja resultasse em desempenho inferior nos primeiros 21 dias de vida, o desempenho subsequente até 77 dias não foi influenciado pela dieta neonatal.

ZAMORA \& VEUM (1979), testando ainda o farelo de soja substituindo a proteina láctea só que em quantidades crescentes nos primeiros 21 dias $125 \%$ e $38 \%$ ou $38 \%$ e $52 \%$ de farelo de soja de 1-12 e de 12-22 dias) observaram maior ganho diário de peso (GDP) e maior eficiéncia alimentar, quando menor proteina de soja foi usada. Os resultados concordam com os de outros autores, que mostraram que o leitão neonato pode se adaptar à substituição parcial da proteina de leite pela proteina de soja. Havendo desempenho satisfatório, pode-se ter uma maior contribuição de proteina, $447 \%$ para $73 \%$ do total de proteina dietética aos 12 dias) a partir do farelo de soja, acompanhada de uma rápida adaptação digestiva do leitão com a idade. 
Concluiram que o nivel de proteina de soja na dieta do neonato pode ser gradualmente aumentado com a idade sem influenciar negativamente o desempenho de leitzes criados artificialmente e o desempenho subsequente (até os 78 dias) não é afet.ado.

Sabe-se que as diferentes formas de proteina de soja (farinha, farelo, concentrado ou isolado) não são bem utilizados e digeridos pelos leitões com menos de 28-35 dias. São várias as razões possiveis para essa menor eficiência de utilização: fatores anti-nutricionais, imbalanços de aminoácidos, desenvolvimento inadequado do sistema enzimático proteolitico, alteraçơes nos processos digestivos, etc (DECUYPERE et alii, 1981).

FERREIRA (1986) trabalhou com extrato de soja, leite de vaca ou de porca para alimentação dos leitóes. A adição ou não de antibiotico também foi testada. Ele sugeriu a possibilidade do uso do extrato de soja como ingrediente sucedâneo de leite a partir do quarto dia de vida, lembrando que o desempenho obtido com leite de porca por aleitamento natural ou artificial é superior.

\subsubsection{OUtros Produtos}

Quando se procura um substituto do leite,
esbarra-se em proteinas vegetais, que normalmente
proporcionam performances inferiores cpor exemplo, a


28.

proteina de soja comparada à proteina lácteà de leitóes jovens. Este fato conduz a busca de fontes alternativas para uso na alimentação do neonato (POND et alii, 1971).

POND et alii (1971), comparando o concentrado

protéico de peixe, como unica fonte protéica, com dietas a base de caseina e isolado protéico de soja não observaram diferenças entre a caseina e o concentrado protéico de peixe em promover o crescimento e na concentração de proteina sérica total, após 21 dias de alimentação. Não houve evidências de toxicidade ou não aceitação do concentrado por leitôes jovens o que sugere que esse pọssa ser usado como única fonte protéica em dietas liquidas para leitত̃es de 2 a 23 dias.

PETTIGREW et alii (1977a), trabalhando com a substituição do leite desnatado em pó por leite peptonizado (digestão triptica de leite desnatado), verificaram que os leitơes apresentaram uma condição raquitica. 0 desempenho dos leitठ̃es com leite peptonizado foi inferior, quanto a GDP e eficiência alimentar e teve maior escore de diarréia.

RODRIGUEZ \& YOUNG (1981), trabalharam com leitðes de 7-22 dias, para testar se cereais como o milho ou o trigo poderiam ser usados como substituto do soro, quando incluido a 30\% na dieta. Năo houve grande diferença de peso aos 22 dias entre os diversos tipos de alimentação cmilho, trigo, dieta liquida, soro e leite de porca). Assim que o leitão começa a comer mais rapidamente, passa a sanhar peso 
também rapidamente, embora sua taxa de crescimento não seja tão elevada quanto a que ocorre com leitơes alimentados automaticamente com dietas liquidas.

As alternativas que têm mostrado desempenho inferior às proteinas lácteas são proteinas da clara do ovo, proteína da soja e combinação de proteína de milho e soja; já a proteína de peixe tem mostrado desempenho equicalente (PETTIGREW \& HARMON, 1977).

\subsubsection{Relação Proteína : energia}

A relação proteina:caloria é de srande importância para o desempenho dos leitões do nascimento aos 21 dias de idade, sendo que tanto as fontes de proteina como as de energia vão influenciar nessa relação.

LECGE \& COALSON (1976) observaram que com o aumento da relação proteina:caloria houve melhora no desempenho de leitões sendo que o melhor resultado obtido foi com 33\% proteina:28\% carboidrato. O mesmo ocorreu com a relação proteína:gordura onde a relação $39 \%: 42 \%$ refletiu no melhor desempenho animal.

Resultados semelhantes foram obtidos por SHERRY et alii (1978a), onde niveis protéicos mais altos ( $\cong 30 \%$ ) ou relação proteina:caloria de 63 \& PB/Mcal ED proporcionaram maiores GDP e eficiência alimentar. Observaram também que a gordura mais insaturada acarretou melhores GDP e eficiéncia 
alimentar. Há indicações de que, quando sordura saturada excede $10 \%$ da dieta, há depressão no GDP.

As proteinas do ovo e leite peptonizado foram insatisfatórias para leitơes neonatos quando comparadas à proteina do leite desnatado seco. Estudos de utilização de gordura mostraram que a energia do óleo de milho foi t.ão bem utilizada como a energia do amido de milho por leitões de 14 dias. E a energia dos óleos de milho e amendoim foi tão eficiente quanto a energia da glucose e da lactose para leitões de 21 dias. Segundo FROBISH et alii (1970) as fontes de gordura como a manteisa, o óleo de coco, o sebo, - óleo de soja ou a gordura hidrolisada de origem animal ou vegetal parecem não serem eficientemente usadas por leitões de 14-21 dias. Os ácidos graxos de cadeias longas têm muito maior influência na digestibilidade de gordura pelo leitão jovem do que o grau de insaturação (SHERRY et alii, 1978b).

2.5. Manejo da alimentação

\subsubsection{Frequíñia da Alimentação}

Com a fémea no inicio da lactação, os leitơes recebem cerca de 24 refeiçб̃es/dia distribuidas regularmente durante as 24 horas. Contudo, sob condições de criação artificial ou após o desmame são fornecidas $2-3$ refeiçơes e normalmente durante o horário de trabalho. Isso predispõe a 
uma sobrecarga no estómago dos membros mais vorazes da leitegada com resultados desastrosos (MANNERS, 1970).

BRAUDE et alii (1970), estudando os aspectos da digestão protéica do leite, observaram que a atividade de enzima proteolftica/g de digesta no estómago foi mais alta em leitões alimentados a intervalos de hora em hora do que naqueles alimentados apenas 2 vezes ao dia, embora a grande variação resultou em diferenças não significativas. A atividade total da enzima foi aumentada com os niveis mais altos de alimentação, mas não foi influenciada pela frequiéncia e a atividade enzimática/g de parede gástrica não foi influenciada nem pela frequiéncia nem pelo nivel de alimentação. Quanto à atividade proteolitica do páncreas, não foi afetada pelo nivel nem frequência, entretanto a niveis mais altos, os conteúdos do ID tiveram maior atividade enzimática. observou-se que a atividade enzimática tanto na parede como nos conteúdos gástricos foram mais altos 15 minutos após a refeição, indicando que a secreção pelos tecidos gastricos é influenciada pela refeição. Logo após esse aumento inicial da quantidade de enzima no estómago, a sua atividade cai rapidamente para os niveis anteriores à alimentação.

o manejo e o regime dietético adotado têm profunda influéncia no desempenho. Fornecendo uma dieta liquida de hora em hora, consegue-se que o leitão, após a separação da mãe, realmente coma, tenha uma melhor digestão e evita-se 
a diarréia pos desmame. Com isso, sem violar a lei fundamental da nutriçäo que diz "não se pode sanhar peso a menos que se coma", torna-se possivel o bom desempenho do leitão (JONES et alii, 1977 e NEWPORT, 1977).

Segundo JONEs et alii (1977) dietas liquidas

fornecidas de hora em hora, com cerca de $11 \%$ das calorias provenientes da proteina de soja são suficientes para um rápido crescimento de leitões minimamente estressados, entre 3-5 semanas de idade.

\subsubsection{FORMA DA DIETA}

MANNERS (1970) cita que, em grupos, e melhor
alimentar leitós com dietas secas ou peletizadas em comedouros automáticos. A secura da ração impõe um limite no consumo e os leitôes ficam menos sujeitos a desenvolver distúrbios digestivos. GUMBY (1986) menciona a vantagem da dieta líquida, em reduzir a perda de alimento, sobre a peletização que, embora tendo a mesma vantagem, onera a ração em $2 \%$ além do custo do equipamento.

Mantendo as condições sanitárias adequadas, E
possivel criar leitóes desmamados com menos de 1 dia de
idade, através de dietas liquidas fornecidas por um
dispensador automático retrigerado, cujos recipientes são
limpos de hora em hora. O leitão é alimentado diariamente
com um volume de $30 \%$ do PV. Nesse sistema consegue-se 3,6


vezes o seu peso do nascimento às 2 semanas de idade, com uma conversão alimentar de $0,6-0,7$ e perdas por morte menores do que $2 \%$ (LECGE, 1975).

A fémea amamenta a cada hora ou hora e meia e só seria possivel simular essa condição articialmente com um dispensador automático. VARLEY et alii (1985) são autores de uma incubadora para leitóes. MENGE \& FROBISH (1976), testando dietas semi-liquidas 3 vezes por dia, observaram que deve-se ter muito cuidado ao comparar as taxas de crescimento registrados por diferentes laboratórios, onde dietas liquidas são usadas, isso por causa das diferenças na MS, no consumo de alimento e no manejo. Diferenças entre raças também devem ser consideradas.

A forma como a dieta é apresentada é bastante importante. BRAUDE \& NEWPORT (1977) forneceram um substituto do leite na forma bquida até os $?$ dias de idade. A partir dal até 28 dias, ou continuaram com essa mesma dieta na forma liquida ou então na forma peletizada. Parece que a dieta liquida é essencial para sarantir o máximo potencial de crescimento aos leitões desmamados aos 2 dias. No entanto, substitui-la por uma dieta peletizada traria maior flexibilidade na formulação da dieta, além de possibilitar simplificaçరes substanciais nos sistemas de alimentação. A dieta líquida foi a que resultou em maior peso aos 28 dias, provavelmente devido ao menor consumo dos animais submetidos à dieta seca cas conversరes alimentares 
foram similares). Verificado o peso desses animais aos 56 dias cressaltando-se que a partir dos 28 dias eles só receberam ração peletizada) a diferença existente foi muito pequena.

NEWPORT (1977) afirma que com a criação artificial pode-se ter uma percentagem de crescimento superior à criação convencional. No entanto, só é possivel ter crescimento máximo com raçôes liquidas que contenham 15\%-20\% de MS, porque a insestão de MS é muito maior do que quando se fornece a mesma ração na forma seca.

LECGE et alii (1979), alojando os leitơes individualmente e alimentando-os de hora em hora com uma dieta liquida composta principalmente de óleo de milho, óleo de amendoim e sólidos de leite não sordurosos, observaram que os leitões que permaneceram recebendo dieta líquida até os 30 dias tiveram maior peso médio do que aqueles que tiveram sua alimentação alterada para ração sólida aos 9 ou 14 dias.

RODRIGUEZ \& YOUNG (1981), testando forma de fornecimento da dieta e habilidade do leitão jovem em usar - amido, substituiram até $30 \%$ do soro por milho e triso em dietas para leitơes desmamados aos 7 dias e avaliados até 22 dias. Comparando o desempenho dos leitões tratados com dieta liquida, milho, trigo, soro ou leite de porca não observaram grande diferença de peso aos 21 dias, embora a dieta liquida tivesse refletido em desempenho superior. 


\begin{abstract}
Em trabalhos relatados por LEIBBRANDT \& KEMP (1987) e VARGAS (1987), o fornecimento de dieta liquida nos 4 dias pós desmame resultou em aumento de 15,5-19,1\% no peso, ao final do experimento.
\end{abstract}




\section{MATERIAL E MÉTODOS}

\subsection{LOCAL}

Este trabalho foi conduzido em instalaçðes da Fazenda Santa Rosa, municipio de Leme, estado de São Pạulo, no periodo de 01 de outubro de 1988 a 15 de janeiro de 1989. A fazenda dista $188 \mathrm{~km}$ da capital do estado, com área de 295 ha e localiza-se a $22^{\circ} 12^{\prime}$ de latitude sul e $47^{\circ} 26^{\circ}$ de longitude oeste de Greenwich.

\subsection{INSTALAÇÕES}

A maternidade utilizada durante 0 periodo
experimental compreendia uma sala única de 50 metros de
comprimento por 14 metros de largura, com 88 gaiolas.
Lateralmente, possuia paredes de tijolos com $1,40 \mathrm{~m}$ de
altura e um pé direito de $3,70 \mathrm{~m}$.
Havia um sistema de janelres (2,30 $\mathrm{m}$ de altura) de
madeira, preso aos pilares de sustentação do telhado que
podia ser regulado para promover maior aeração do ambiente.


Além disso, ela era dotada de 4 ventiladores instalados nos 2 corredores principais da instalação.

As saiolas metálicas de parição, medindo $1,90 \mathrm{~m}$ de largura por 2,28 $\mathrm{m}$ de comprimento, eram colocadas lado a lado, formando 2 grandes grupos de 4 fileiras de 11 gaiolas cada uma, sendo fixadas em pisos de concreto, com as laterais de piso quadriculado em polietileno. A parte posterior era com piso ripado, sobre um fosso de $44 \mathrm{~cm}$ de largura para coleta de dejetos. Cada gaiola possuia comedouros simples e bebedouros automáticos tipo concha, para a matriz e para os leitós.

A creche utilizada compreendia 5 salas parcialmente independentes, considerando que o corredor central não tinha paredes até o teto. Lateralmente possuiam paredes de tijolos com $1,25 \mathrm{~m}$ de altura. Havia um sistema de cortinado preso aos pilares de sustentação do telhado, que podia impedir a ação de ventos frios ou promover uma maior aeração.

Cada sala possuia 14 saiolas metálicas, medindo $1,87 \mathrm{~m}$ por $2,00 \mathrm{~m}$, colocadas uma ao lado da outra, formando duas filas paralelas de 7 gaiolas cada uma. Essas gaiolas eram colocadas a uma altura de $55 \mathrm{~cm}$, possuiam piso quadriculado de polietileno, 2 comedouros automáticos na lateral da gaiola e um bebedouro tipo chupeta. Todas as salas tinham o piso construido com uma declividade tal que a parte central era mais profunda, favorecendo a limpeza 
dos dejetos que era feita diariamente.

\subsection{ANIMAIS}

\begin{tabular}{|c|c|c|c|c|}
\hline $0_{3}$ & animais & 6306 & leitoles) & utilizados \\
\hline provenientes & de & fêmeas & mestiças & resultantes \\
\hline
\end{tabular}
varrofes Landrace, Large white ou Duroc.

o critério para seleção das fémeas foi a ordem de parição que esteve entre 3o e 60 parto.

\subsection{RAÇÕES EXPERIMENTAIS}

Os leitðes permaneceram recebendo apenas leite da porca até os 21 dias de idade, quando então foram submetidos a 8 tratamentos correspondentes a 8 tipos de raçত̃es experimentais. Tais raçðes eram baseadas em milho, farelo de trigo, farelo de soja, vitaminas, minerais e sucedăneo de leite.

o conjunto de tratamentos foi uma combinação entre trés fatores que estão listados a seguir, sendo um deles a peletização que foi feita na fábrica de ração do Departamento de Zootecnia da Escola Superior de Agricultura "Luiz de Queiroz".

- 2 formas de fornecimento de leite:

L1 : Leite em pó incorporado à ração 
L2 : Leite diluido em água

- 2 niveis de leite nas dietas secas e 1 nivel na dieta liquida:

$\begin{array}{lcc}\text { L1 : } & \text { Pré-inicial } & \text { Inicial } \\ & \% & \% \\ & 14,4 & 9,6 \\ & 9,6 & 4,8 \\ \text { L2 : } & \text { Pré-inicial } & \text { Inicial } \\ & 10 & \% \\ \text { 2 formas de ração : } & 0 \\ \text { R1 : Farelada } & \\ \text { R2 : Peletizada } & \end{array}$

Foram formuladas os 8 tipos de raçôes descritas abaixo, cujas composiçశ̃es percentuais e conteúdos em nutrientes esperados se encontram nas Tabelas 3 e 4 .

T1 : Farelada contendo $14,4 \%$ de leite em pó incorporado à ração da fase pré-inicial e $9,6 \%$ de leite em pó incorporado à ração da fase inicial.

T2 : Farelada contendo $9,6 \%$ de leite em po incorporado à ração da fase pré-inicial e 4,8\% de leite em pó incorporado à ração da fase inicial.

T3 : Peletizada contendo $14,4 \%$ de leite em pó 
incorporado à ração da fase pré-inicial e $9,6 \%$ de leite em pó incorporado à ração da fase inicial.

T4 : Peletizada contendo $9,6 \%$ de leite em pó incorporado à ração da fase pré-inicial e 4,8\% de leite em pó incorporado à ração da fase inicial.

T5 : Farelada não contendo leite em pó na ração, mas com o leite em pó diluido a 10\% em água apenas na fase pré-inicial.

T6: Peletizada não contendo leite em pó na ração, mas com o leite em pó diluido a 10\% em água apenas na fase pré-inicial.

T7 : Farelada não contendo leite em pó incorporado à ração nem diluido em água.

T8 : Peletizada não contendo leite em pó incorporado à ração nem diluido em água.

- periodo experimental incluiu duas fases de fornecimento de ração : pré-inicial, fornecida a partir dos 21 aos 49 dias ( 3 semanas pós-desmame) de idade e inicial, fornecida desta data até os 61 dias ca idade de transferencia dos leitð̌es).

A composição química aproximada e o conteúdo energetico dos ingredientes das raçбes experimentais são apresentados na Tabela 1 e a composição em aminoácidos aparece na Tabela 2. 
As composiçöes percentuais e os conteúdos em nutrientes esperados nas raçóes pré-inicial (21\% de PB) $e$ inicial (19\% de PB) são apresentados nas Tabelas 3 e 4.

Todas as raçôes experimentais foram enriquecidas com vitaminas, microminerais e aminoácidos, alem de antioxidante, conforme as Tabelas 5 e 6 .

Tabela 01 - Composição química aproximada e conteúdo energético dos ingredientes.

Ingredientes

Milho Farelo Farelo Calca- Fos- Leite
Soja Triso rio calcio

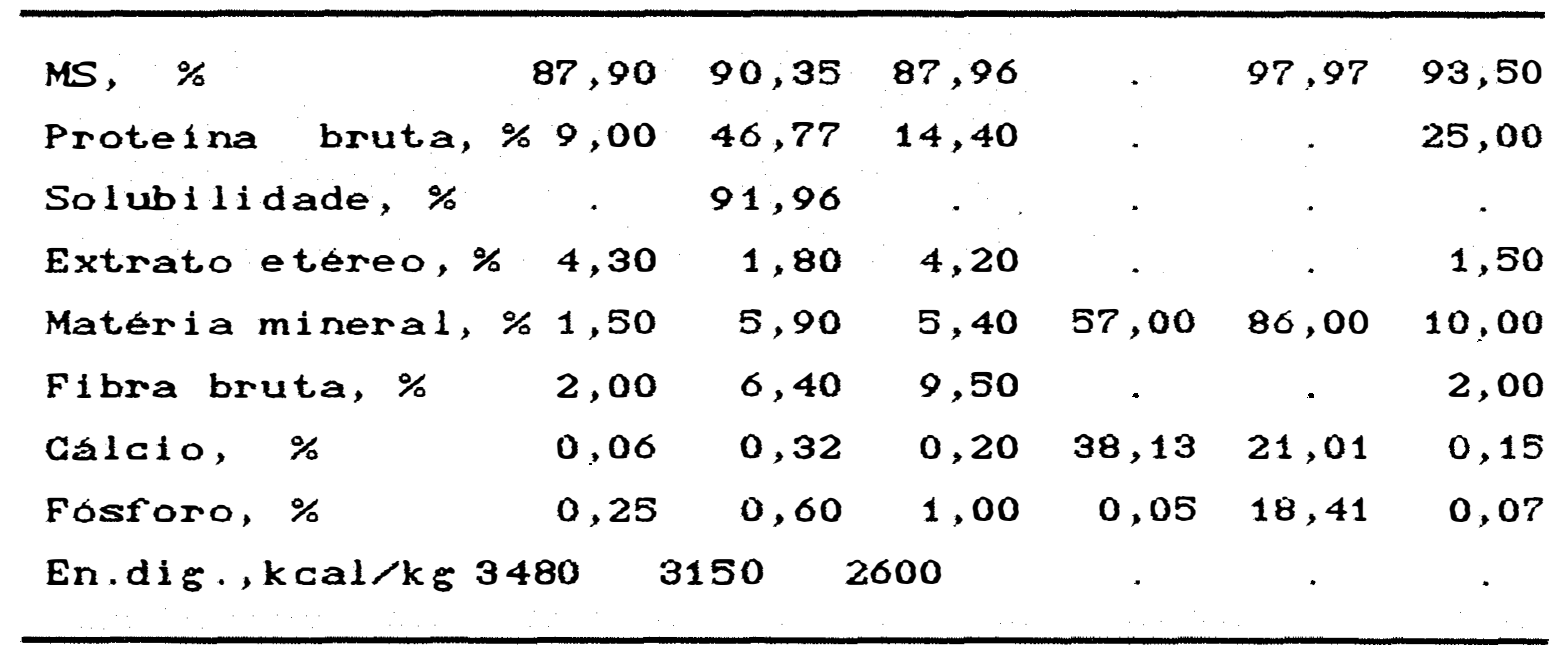

a. Laboratório de controle de qualidade da supre Mais Produtos Bioquímicos Ltda, exceto pelo valor de En. dig.

b. Niveis de garantia do supre leite suino da supre Mais
Produtos eioquímicos lta, além do enriquecimento em vitaminas e minerais 
Tabela 02 - Composição dos ingredientes em aminoacidos.

Ingredientes

\begin{tabular}{lcccc} 
Aminoácidos & Milho & $\begin{array}{c}\text { Farelo } \\
\text { Soja }\end{array}$ & $\begin{array}{c}\text { Farelo } \\
\text { Trigo }\end{array}$ & Leite \\
\cline { 2 - 5 } Lisina & 0,24 & 2,95 & 0,64 & 1,97 \\
Metionina & 0,20 & 0,68 & 0,24 & 0,98 \\
Histidina & 0,22 & 1,08 & 0,34 & \\
Arsinina & 0,44 & 2,33 & 0,97 \\
Treonina & 0,34 & 1,77 & 0,46 \\
Gicina & 0,36 & 1,94 & 0,86 & \\
Valina & 0,40 & 2,23 & 0,69 \\
Isoleucina & 0,32 & 2,13 & 0,50 \\
Leucina & 1,17 & 3,52 & 0,96 \\
Fenilalanina & 0,45 & 2,33 & 0,59 \\
Triptofano & 0,09 & 0,67 & 0,20 \\
Gistina & 0,15 & 0,09 & 0,32 & 0,67 \\
\hline
\end{tabular}

a. Laboratório de controle de qualidade da supre Mais Produtos Bioquímicos Ltda

b. Niveis de garantia do supre leite suíno da supro mais Produtos Bioquímicos lida, além do enriquecimento em vitaminas minerais 
Tabela 03 - Composição percentual das raçóes experimentais pré-inicial e inicial.

\section{Tratamento}

\begin{tabular}{|c|c|c|c|c|c|}
\hline $\mathrm{T} 1 \mathrm{e}$ & r3 & $\mathrm{T} 2 \mathrm{e}$ & $\mathrm{T} 4$ & T5 a & T8 \\
\hline $\begin{array}{c}\text { Pré } \\
\text { Inicial }\end{array}$ & $\begin{array}{l}\text { Ini- } \\
\text { cial }\end{array}$ & $\begin{array}{c}\text { Pré } \\
\text { Inicial }\end{array}$ & $\begin{array}{l}\text { Ini- } \\
\text { cial }\end{array}$ & $\begin{array}{c}\text { Pré } \\
\text { Inicial }\end{array}$ & $\begin{array}{l}\text { Ini- } \\
\text { cial }\end{array}$ \\
\hline
\end{tabular}

$\begin{array}{lrrrrrr}\text { Milho moido } & 46,60 & 52,45 & 47,80 & 53,95 & 48,90 & 53,55 \\ \text { Fare. soja, } 6 \%{ }^{a} & 23,80 & 20,80 & 26,90 & 23,30 & 32,50 & 26,30 \\ \text { Fare. trigo } & 9,70 & 11,00 & 10,20 & 11,70 & 13,00 & 14,00 \\ \text { Açucar } & 2,00 & 3,00 & 2,00 & 3,00 & 2,00 & 3,00 \\ \text { Calcário,38\% a } & 1,30 & 1,20 & 1,30 & 1,20 & 1,40 & 1,30 \\ \text { Foscalcio,45\% a } & 1,10 & 1,00 & 1,10 & 1,00 & 1,10 & 0,90 \\ \text { Salmoido } & 0,40 & 0,40 & 0,40 & 0,40 & 0,40 & 0,40 \\ \text { Mecadox } & 0,20 & 0,05 & 0,20 & 0,05 & 0,20 & 0,05 \\ \text { Supre Leite Sui }{ }^{a} 14,40 & 9,60 & 9,60 & 4,80 & - & - \\ \text { Mist.vitaminicab } & 0,40 & 0,40 & 0,40 & 0,40 & 0,40 & 0,40 \\ \text { Mist.mineral } c & 0,10 & 0,10 & 0,10 & 0,10 & 0,10 & 0,10\end{array}$

Tota 1 $100,00100,01 \quad 100,00100,00 \quad 100,00100,00$

a Ver composiça na Tabela 1

b. Ver composição na rabela 5

c. Ver composiçäo na rabela 6 


\begin{abstract}
Tabela 04 - Conteúdos em nutrientes esperados das raçōes experimentais pré-inicial e inicial. ${ }^{a}$
\end{abstract}

\begin{tabular}{|c|c|c|c|c|c|c|}
\hline \multirow{3}{*}{$\begin{array}{c}\text { Especifica } \\
\text { çöes }\end{array}$} & \multicolumn{6}{|c|}{ Tratamento } \\
\hline & \multicolumn{2}{|l|}{$\mathrm{T} 1$ e $\mathrm{T} 3$} & \multicolumn{2}{|l|}{$T 2$ e $T 4$} & \multicolumn{2}{|l|}{ T5 a T8 } \\
\hline & $\begin{array}{c}\text { Pré } \\
\text { Inicial }\end{array}$ & $\begin{array}{l}\text { Ini- } \\
\text { cial }\end{array}$ & $\begin{array}{c}\text { Pré } \\
\text { Inicial }\end{array}$ & $\begin{array}{l}\operatorname{In} i_{-}^{-} \\
\text {cial }\end{array}$ & $\begin{array}{c}\text { Pré } \\
\text { Inicial }\end{array}$ & $\begin{array}{l}\text { Ini- } \\
\text { cial }\end{array}$ \\
\hline E.di\&.kcal/kg 31 & 155 & 89 & 3158 & 90 & 3148 & 81 \\
\hline Prot .bruta, \% & 20,54 & 18,59 & 20,90 & 18.72 & 21,48 & 19,15 \\
\hline Fibra bruta, \% & 3,63 & 3,59 & 3,82 & 3,77 & 4,29 & 4,08 \\
\hline Ext.etéreo, \% & 3,99 & 3,86 & 3,74 & 3,62 & 3,23 & 3,36 \\
\hline Mat.mineral, \% & 5,36 & 4,93 & 5,31 & 4,94 & 5,30 & 4,83 \\
\hline Cálcio, \% & 0,91 & 0,88 & 0,90 & 0,89 & 0,92 & 0,88 \\
\hline Fósforo tot, $\%$ & 0,64 & 0,61 & 0,64 & 0,62 & 0,65 & 0,60 \\
\hline Fósforo disp, $\%$ & 0,37 & 0,34 & 0,37 & 0,34 & 0,36 & 0,32 \\
\hline Lisina, \% & 1,18 & 1,00 & 1,18 & 0,99 & 1,18 & 0,99 \\
\hline Metionina, $\%$ & 0,43 & 0,37 & 0,41 & 0,34 & 0,36 & 0,32 \\
\hline Triptorano, \% & 0,32 & 0,27 & 0,31 & 0,26 & 0,29 & 0,25 \\
\hline
\end{tabular}

a. Ver composição nas rabelas 1,2 e 
Tabela 05 - Composição das miaturas vitaminicas das raçర̈es pré-inicial e inicial.

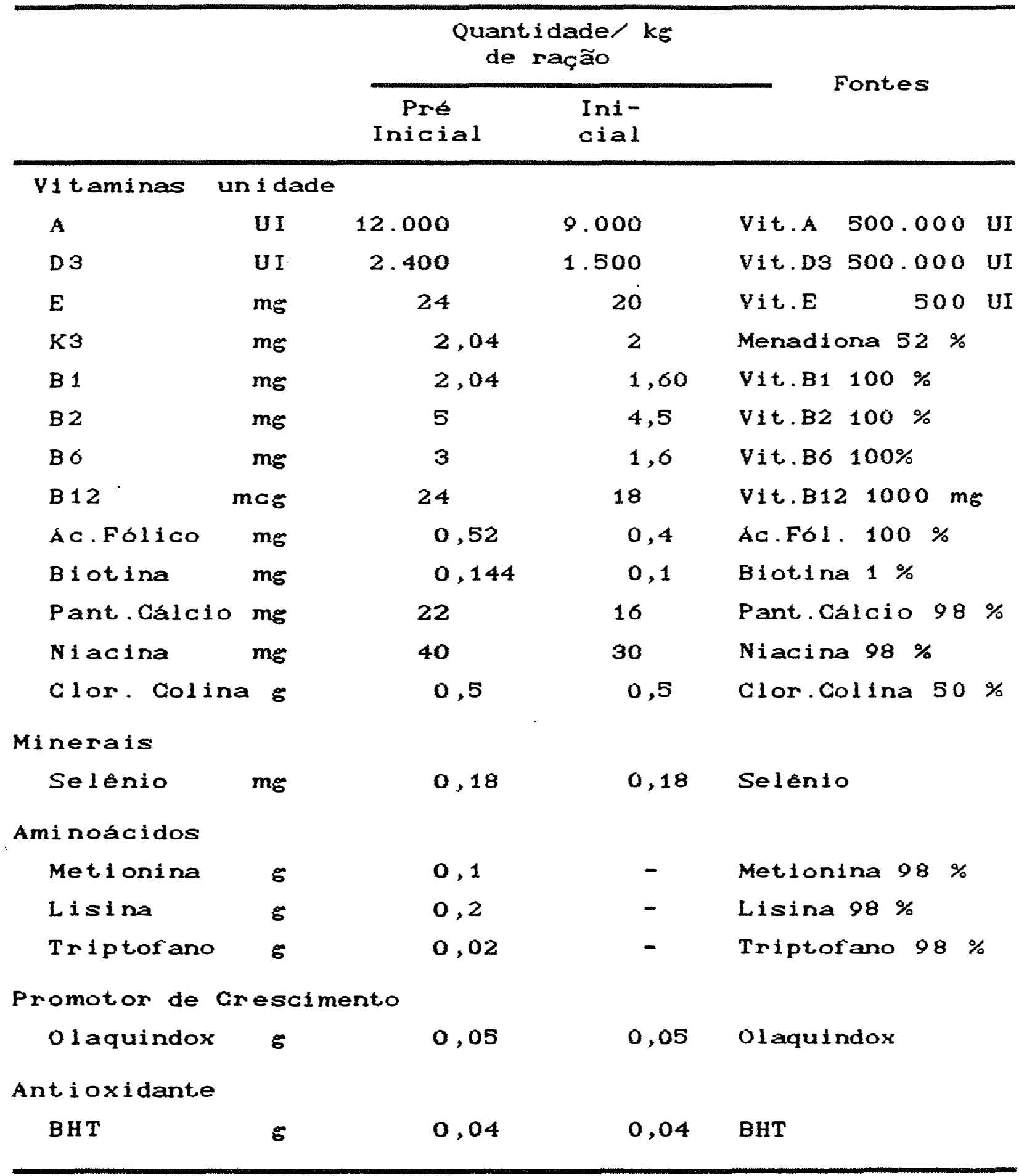




Tabela 06 - Conteúdos em micro minerais das raçơs
pré-inicial e inicial.

\begin{tabular}{llll}
\hline & & $\begin{array}{c}\text { Quantidade } \mathrm{kg} \\
\text { de ração }\end{array}$ & Fontes \\
\hline Manganés & $\mathrm{mg}$ & 45 & Sulfato de Mn \\
Ferro & $\mathrm{mg}$ & 88 & Sulfato de $\mathrm{Fe}$ \\
Cobre & $\mathrm{mg}$ & 15 & Sulfato de Cu \\
Iodo & $\mathrm{mg}$ & 01 & Iodato de Ca \\
Zinco & $\mathrm{mg}$ & 80 & Oxido de $\mathrm{Zn}$ \\
& & &
\end{tabular}

Por questão de segurança, devido ao periodo experimental relativamente longo ccerca de trés meses e meio), foram realizadas analises quimicas de amostras de raçớes, para controle de sua composição, cujos resultados podem ser observados nos Apêndices 1 e 2 . As variaçớs verificadas nos teores dos nutrientes foram pequenas, não acarretando problemas com a composição das rações previamente calculadas.

Durante os primeiros 21 dias do periodo experimental, os animais tinham acesso apenas ao leite da porca; dos 21 aos 49 dias, os leitôs receberam a ração pré-inicial, sendo que nos tratamentos $T 5$ e $\mathrm{To}$ os animais tinham ainda acesso a dieta liquida. Finalmente, para 0 periodo dos 49 aos 61 dias, os leitoes receberam apenas a ração inicial. 


\subsection{Manejo das matrizes em lactação e dos leitões LACTENTES}

As rações das fémeas foram fornecidas úmidas, três vezes ao dia, em quantidades que dependiam da capacidade de consumo da fémea $(+/-5,0 \mathrm{~kg})$, desde a parição até a ocasião do desmame dos leitóes aos 28 dias de idade. Durante este periodo, o controle do consumo de ração das fémeas foi feito individualmente.

As matrizes foram pesadas aos 110 dias de sestação, no dia do parto e também aos 28 dias de lactação (momento do desmame - Apéndice 11).

Os partos foram sempre assistidos e logo após a execução do manejo normalmente empregado climpeza, corte do cordão umbilical, aplicação de $0,2 \mathrm{ml}$ de Tribrissen + 1,0 ml Vitagold, corte da cauda e aplicação de ferro, $1 \mathrm{ml}$ de Gleptosil injetável no prazo de 24 horas), os leitठes foram colocados junto com as mães para que pudessem mamar o colostro.

As leitegadas foram então uniformizadas em número de 10 e com peso médio inicial de $1,54+/-0,25 \mathrm{~kg}$. Desde 0 nascimento até o desmame, os leitžes tiveram acesso a aquecimento artificial serado por uma lámpada de luz infravermelha (250 W), colocada em um canto da gaiola de parição onde existia um espaço coberto $(60 \times 86 \mathrm{~cm})$.

Os leitశes machos foram castrados aos 10 dias 
quando receberam $0, \ddot{z} \mathrm{ml}$ de Tribrissen injetável.

As raçöes foram fornecidas a partir dos 21 dias de idade, mas o consumo só ocorreu realmente por ocasiäo do desmame. Durante a última semana do periodo de lactaçäo, os consumos de raçäio e de dieta liquida dos leitões foram controlados semanal e diariamente, respectivamente.

us leitões foram pesados por leitegada no dia do nascimento e após a uniformização e depois semanalmente, sem jejum, aos $7,14,21$ e 28 dias. Com 28 dias de idade os leitões foram desmamados e conduzidos às salas de creche.

De alguns dos leitões submetidos às rações peletizadas, foram feitas 5 coletas de sangue, para análise de imunoglobulinas séricas (Ig) como será descrito posteriormente.

\subsection{Manejo dos Leitões Pós-Desmame}

Nas primeira e segunda semanas pós-desmame a distribuição da raçăo foi controlada: no primeiro dia, apenas 1 vez à tarde; no segundo dia, 2 vezes, cuma cedo e uma à tarde); no terceiro dia, 3 vezes; e a partir do quarto dia, 4 vezes e, assim, ate a segunda semana, aumentando o fornecimento gradativamente. Só a partir da terceira semana, o fornecimento foi ad libitum nos comedouros automáticos. A água foi fornecida à vontade em todo periodo experimental e a dieta liquida, nos 
tratamentos especificos (T5 e T6), também foi fornecida à vontade, durante o periodo de trabalho.

Aos 42 dias os leitőes foram vacinados contra peste suina.

As leitegadas foram pesadas, sem jejum, aos 35, 42, 49 e 61 dias de idade. O consumo de ração pré-inicial foi anotado semanalmente para cada leitegada até os 49 dias e a partir dal o mesmo ocorreu para a ração inicial. o consumo de leite foi computado diariamente até os 49 dias. Nessa fase também foram feitas coletas de sangue aos 35 e 61 dias para análise de imunoglobulinas séricas.

\subsection{Coleta das amostras de sangue}

Foram realizadas 602 coletas de sangue da veia cava anterior de $3-5 \mathrm{ml}$ por animal. 0 material foi recebido em tubo de centrifuga, centrifugado e o soro resultante transferido para dois frascos devidamente identificados e armazenados a $-20^{\circ} \mathrm{C}$ até a data de análise, realizada no Departamento de Zoologia da Escola Superior de Agricultura "Luiz de Queiroz".

As coletas foram feitas apenas em leitares que seriam submetidos aos tratamentos contendo raçôes peletizadas. O número de leitơes variou com o tratamento e bloco conforme observado na Tabela 7 .

Foram feitas set.e coletas por animal, obedecendo o 
seguinte esquema : 24 e 48 horas, $10,21,28,35$ e 61 dias de ldade dos leitőes.

Tabela of - Número de leitäes amostrados para determinação de imunoglobulinas séricas.

\begin{tabular}{llllll}
\hline \multirow{2}{*}{ Tratamento } & \multicolumn{5}{c}{ Bloco } \\
\cline { 2 - 5 } & 1 & 2 & 3 & 4 \\
\hline T3 & 5 & 5 & 5 & 6 \\
T4 & 4 & 6 & 6 & 6 \\
T6 & 5 & 6 & 5 & 5 \\
T8 & 5 & 6 & 5 & 6 \\
\hline
\end{tabular}

\subsection{ANÁlise das amostras}

As imunoglobulinas séricas dos leitð̋es foram quantificadas segundo o metodo descrito por McEVAN et alii (1970), que se refere à leitura espectrofotométrica de turvação, obtida da reação das imunoglobulinas com o sulfato de zinco heptahidratado, $\mathrm{ZnSO}_{4} 7 \mathrm{HzO}$. Preparou-se a cada bateria de amostras uma nova solução de sulfato de zinco heptahidratado com $208 \mathrm{mg}$ de $\mathrm{ZnSO}_{2} .7 \mathrm{HzO}$ em $1000 \mathrm{ml}$ de HzO destilada $(0,0007 M)$ e mantida em ebullção por 20 minutos, para eliminar a presença de $\mathrm{CO}_{2}$ que influencia a turvação e, consequentemente, a densidade optica. Todas as soluções utilizadas nesse método foram mantidas livres de CO2. Para isso montourse um sistema com tubos de látex e 
pipetadores, de maneira que todo ar consumido na operação borbulhasse em solução de $\mathrm{NaOH}$, antes de entrar no circuito fechado. A temperatura ambiente do laboratorio foi estabilizada a $21^{\circ} \mathrm{C}$ durante as reaçốs e lelturas.

Procedeu-se a leitura de densidade optica ou absorbancia, no espectrofotómetro (Coleman Junior II) em comprimento de onda de $660 \mathrm{~nm}$, após adição de $100 \mu 1$ de amostra de soro a $6 \mathrm{ml}$ da solução de $\mathrm{ZnSO}_{4} .7 \mathrm{H}_{2} \mathrm{O}$ e incubação por 60 minutos.

Utilizaram-se unidades $2 S T^{3}$ c'Zinc Sulfate Turbidity") para expressar a concentração de anticorpos séricos (densidade optica $\times$ 100). Para se estimar a concentração real em mg de imunoglobulinas séricas $/ m l$, foi obtida uma curva padrão de densidade optica x concentração de imunoglobulinas séricas $(\mathrm{mg} / \mathrm{ml})$ pelo método de eletroforese com sel de poliacrilamida, segundo BREWER \& ASHWORTH (1969). Foram utilizadas 12 amostras para se estabelecer a correlação entre os valores obtidos no método ZST e o processo eletroforético, que geraram a equação ( 1 ). Foram caracteristicas do método, sel inferior de pollacrilamida $7,5 \%$ corrido em pH 8,3 submetido a amperagem de 1,5 volt/tubo por cerca de 1,5-3 horas, tampão

3. Unidades ZST = Absorbancia lida $\times 100$, estima a concentração de $\mathrm{Ig}(\mathrm{mg} / \mathrm{ml})$ no presente estudo. 
tris-glicina, gel inferior ("lower gel") $=6,2 \mathrm{~cm}$. Foi feita diluição da amostra com $0,1 \mathrm{ml}$ de soro $+8.0 \mathrm{ml}$ tris-glycina, depois amostrado $50 \mu l$ por tubo aplicada com micro seringa Hamilton, colocada em sacarose por amostra $10 \%(0,8 \mathrm{ml}=0,08 \mathrm{~g}$ sacarose/tubo $)$ e a coloração feita com amido black $10 B$ C1\% em ác. acético $7 \%=1$ g amido black em $100 \mathrm{ml}$ ác. acético). A descoloração feita com ácido acético $7 \%$ até a revelação das bandas.

A percentagem em composição das bandas foi determinada com um densitómetro (CANALCO MODEL K), acoplado a um registrador e, por não estar ligado a um integrạdor automático, a quantificação foi feita com auxilio de um planimetro utilizando somente leituras coincidentes.

Para se fazer o cálculo da percentagem da área representada pelas gamaglobulinas, a área total foi determinada pela proteina total conforme o método do biureto segundo REINHOLD (1953). A 100 fll da amostra de soro foram adicionados $4,9 \mathrm{ml}$ de $\mathrm{NaOH}(0,75 \mathrm{~N})$ e $1 \mathrm{ml}$ do reativo de biureto $\langle 17,3 \quad s$ de sulfato de cobre pentahidratado mais $173, g$ de citrato de sódio). Após a reação dos elementos quimicos com a amostra (20 minutos) procedeu-se a leitura no espectrofotómetro com comprimento de onda ajustado em 545 nm. A proteina utilizada para estabelecimento da curva padrão foi a albumina fração 5 da Sigma (4) 5 de albumina diluidas em solução salina e preparados padrões com 2, 4, 8 e $10 \mathrm{~g} / 100 \mathrm{ml}$. 
A equação resultante foi :

$y=134,2998 x-12,1964$ (1),

onde: $\quad x=$ absorbância ou densidade óptica

$y=$ concentração de imunoglobulinas séricas em $m g / m l$

com coeficiente de correlação $r=0,81$

- efeito de hemólise nas amostras foi

corrigido segundo o método de PFEIFFE: et alii (1977), através da fómula:

[ ] real Ig = leitura turvação - [A540 $\times 23]$ (2), onde :

[ ] real Ig $=$ Concentração real de Ig em $\mathrm{mg} / \mathrm{ml}$; leitura de turvação $=$ absorbáncia em $660 \mathrm{~nm}$, convertida em $\mathrm{mg} / \mathrm{ml}$ segundo a equação (1);

A540 = absorbància em $540 \mathrm{~nm}$ do soro com diluição 1:20.

\subsection{Delineamento EXPERIMENTAL}

o delineamento experimental utilizado foi 0 de blocos casualizados, com 8 tratamentos e 4 repetiçôes, constituindo cada lote de 10 animais a unidade experimental para os dados referentes a ganho de peso, consumo de ração e conversão alimentar.

Os dados de desempenho, ganho diário de peso 
(GDP), consumo diário de ração (GDR), exceto a conversão alimentar (CA) foram submetidos a uma análise de covariáncia. Para cada variável procurou-se estudar. o modelo mais completo possivel, utilizando-se, como covariável, o peso médio inicial em cada periodo estudado. Para comparação entre médias de tratamentos foi usado o teste $F$ de contrastes ortogonais.

No caso da análise de imunoglobulinas séricas, foi utilizado o mesmo delineamento de blocos casualizados, porém considerando apenas 4 tratamentos, equivalentes às raçб̃es peletizadas, $\mathrm{T} 3, \mathrm{~T} 4, \mathrm{~T} 6$ e $\mathrm{T} 8,4$ repetiçס̃es e o número de leitð̃es amostrados variável, conforme Tabela 7; e com parcelas subdivididas, onde o periodo experimental foi considerado como sub-parcela. Foram pré-estabelecidas 7 datas de coletas, a saber, 1, 2, 10, 21, 28, 35 e 61 dias.

Para comparação entre tratamentos e tratamentos dentro de cada data de coleta, foi utilizado, a partir de valores de $F$ significativos, o teste $F$ de contrastes ortogonais. A análise da relação entre datas de amostragem e unidades ZST foi estudada através de diferentes modelos matemáticos. A cada ponto de amostragem (1, 2, .. 61) as concentrações de Is sérica foram analisadas para estudar o possivel efeito dos tratamentos de acordo com o modelo de blocos casualizados com mesmo número de repetiçð̃es.

Todos os dados foram então submetidos a análise de variáncia, utilizando o programa SANEST - Sistema de 
Análise Estatistica (ZONTA, 1983). 


\section{RESULTADOS E DISCUSSÃO}

\subsection{Caracteristicas de Desempenho}

\subsection{1. ganho Diário de Peso}

Os dados provenientes das pesagens das leitegadas encontram-se no Apéndice 04 e os valores de ganho diário de peso (GDP), em $\mathrm{kg}$, para as fases pré-inicial, inicial e periodo total estão no Apéndice 0 ?.

A representação sráfica dos resultados de peso médio, de acordo com vários modelos, é ilustrado na Figura 02.

Na Tabela 08 são apresentadas as médias de GDP de leitões de 21 a 61 dias de idade, desmamados aos 28 dias. Os dados estão agrupados conforme as fases pré-inicial (21 a 49 dias), inicial ( 49 a 61 dias) e total (21 a 61 dias), sendo que a primeira está subdividida em semanas. As médias estão ajustadas por covariáncia para mesmo peso médio inicial de acordo com o periodo apresentado. Os resultados da análise de variáncia para os periodos que apresentaram 
significancia estatistica, estão apresentados nos Apandices 17,19 e 20 .

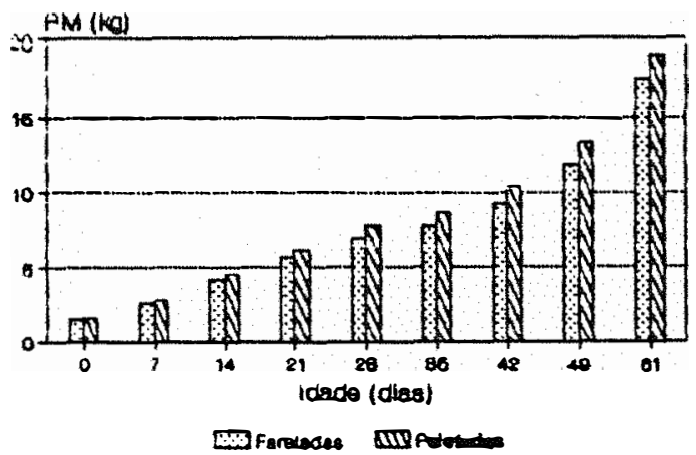

(A)

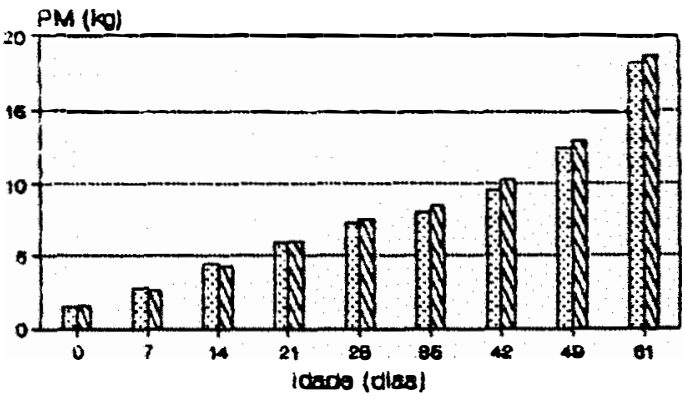

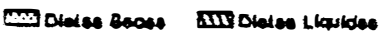

(a)

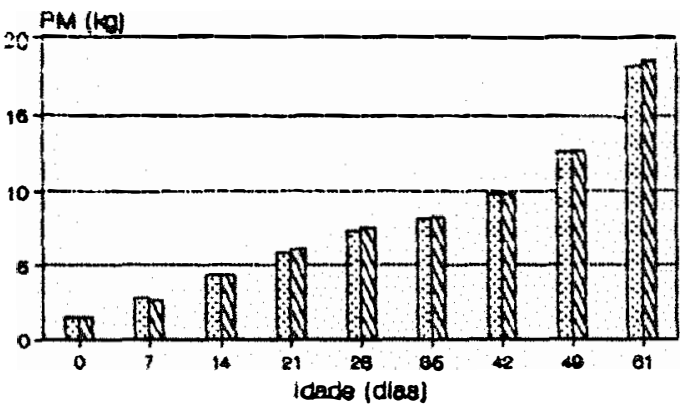

Lid Lill anto conte

(B)

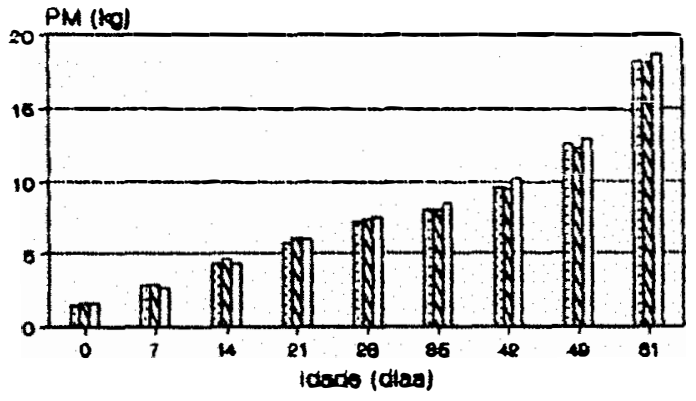

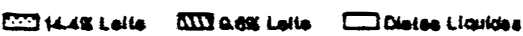

(D)

Figura 02 - Representação sráflca dos pesos médios, raçốes fareladas vs peletizadas (A), com sucedáneo de leite vs controle (B), secas vs liquida (C) e $14,4 \%$ vs $9,6 \%$ vs liquida (D). 
58.

Tabela 08 - Médias de ganho diário de peso ajustadas para o mesmo peso médio inicial referente a cada periodo, em $\mathrm{kg}$.

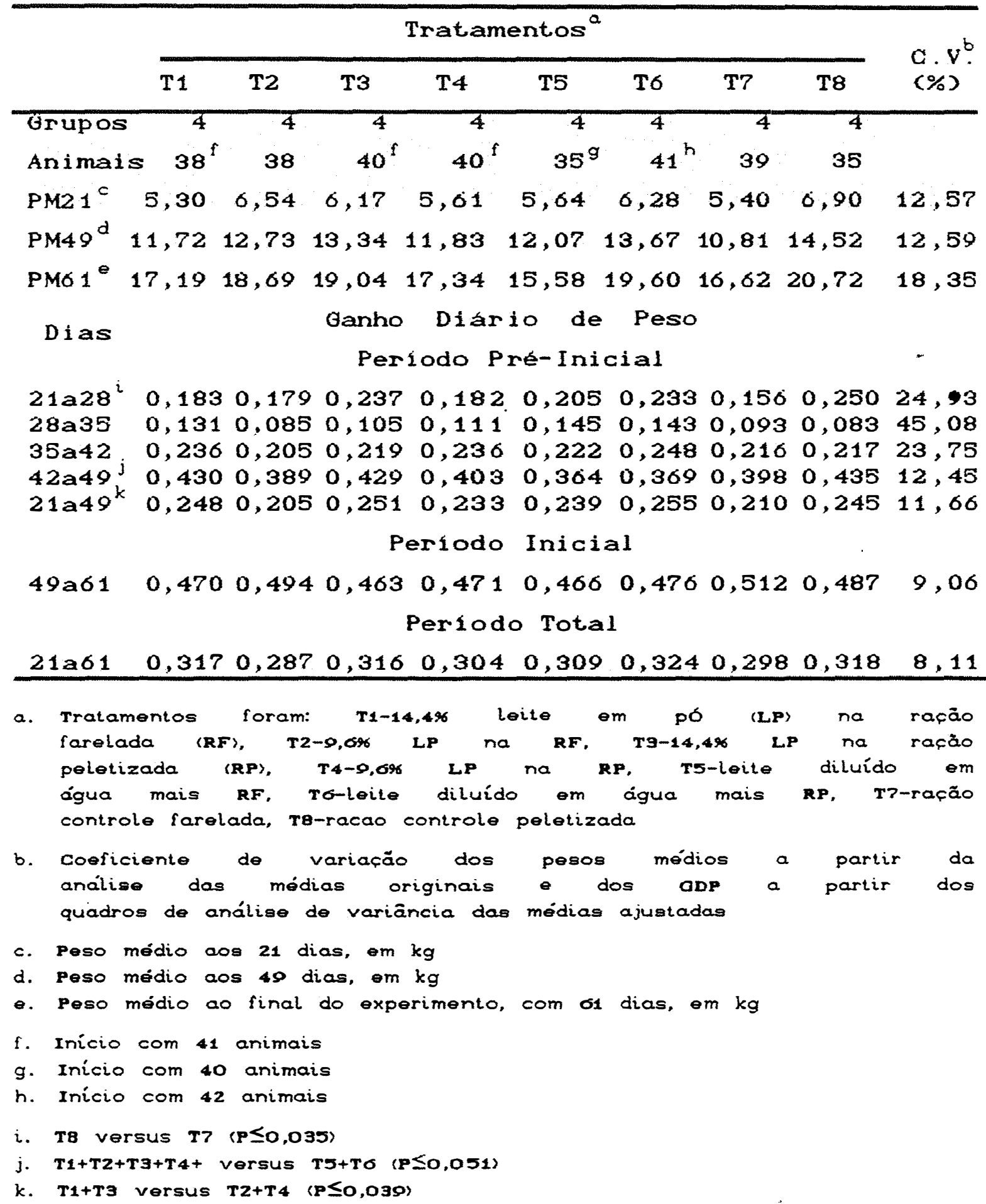


Em geral, a peletização resulta em ganhos mais rapidos. No entanto, no presente estudo nem todas as dietas que foram peletizadas mostraram tal efeito, principalmente nos leitões submetidos aos tratamentos $\mathrm{T} 1$ e T3, como mostra a Figura 03.

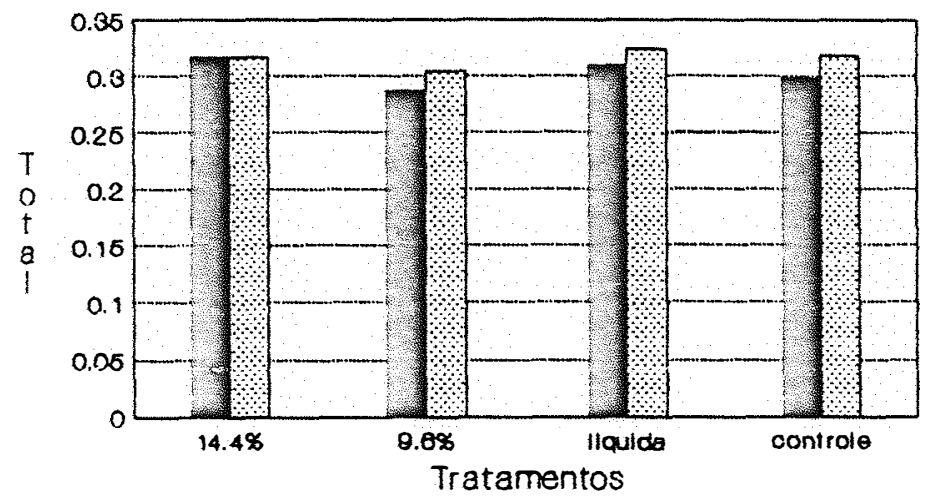

Farelade Polellzade

\section{(A)}

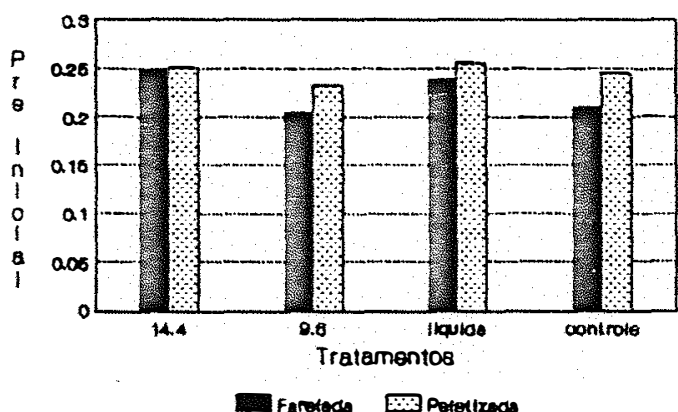

(B)

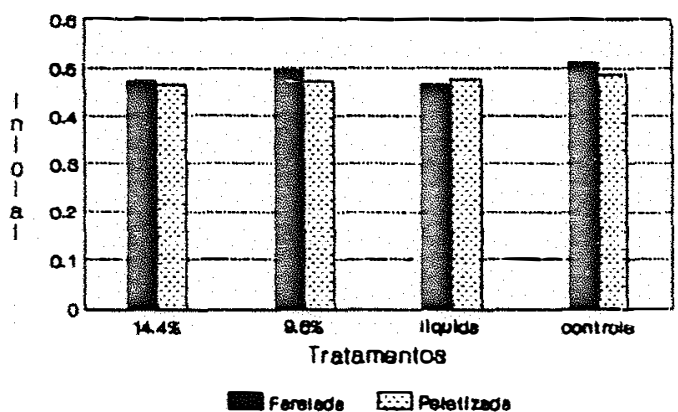

(C)

Figura os - Efeito da peletização no GDP, no periodo totial (A) e fases pre-inicial (B) e inicial (c). 
60.

Apenas na primeira semana de distribuição dos tratamentos, 21 a 28 dias, póde-se observar diferença estatistica no GDP $(P \leq 0,035)$ entre as formas farelada e peletizada das dietas controle, 0,250 versus 0,156 kg/dia. No entanto, essa diferença não deve ser atribuida aos tratamentos. Nessa semana os leitठ̃es se encontravam com a mãe e o consumo de ração foi minimo $c 0,003$ e 0,008 kg/dia para os tratamentos $T 7$ e T8 respectivamente), não justificando portanto a diferença ocorrida. Embora o ajuste por covariáncia tenha sido feito para PM aos 21 dias, a eficiência desse artificio $(E=96 \%)$ não foi suficiente pạa reduzir as diferenças entre os dois grupos de animais, sendo que as outras variáveis, como principalmente produção de leite das fémeas, pode ser atribuida tal diferença. Nas outras dietas, embora houvesse aumento de GDP, tal variável não foi superior estatisticamente.

Embora na primeira semana pós-desmame $<28$ a 35 dias) as dietas liquidas tenham apresentado um GDP $(0,144$ kg/dia) maior do que as dietas com 14,4\% sucedáneo de leite $(0,118 \mathrm{~kg} / \mathrm{dia})$ ou com 9,6\% (0,098 kg/dia), correspodendo a $22 \%$ e 47\%, respectivamente, de incremento no GDP, tais diferenças não foram significativas ( $P>0,05)$. Essa melhora deixou de existir nas semanas seguintes. Nessa semana, observou-se o maior C.V.\% (45,08\%), não identificando diferenças entre tratamentos e tambem nesse intervalo a eficiéncia do ajuste por covariáncia, para mesmo PM aos 28 
dias melhorou em apenas 5\% (E=105\%) os dados obtidos.

Para que os leitßres continuem com uma alimentação

normal apos o desmame, alsuns autores sugeriram o fornecimento de dietas liquidas durante 4 ou 5 dias após o desmame, realizado entre 21 e 28 dias (LEIBBRANDT \& KEMP, 1987 e VARGAS, 1987). Os resultados obtidos no presente estudo $\operatorname{CGDPo-28}=0,209, \operatorname{GDP21-49}=0,236 \mathrm{~kg})$ foram inferiores aos citados pelos referidos autores (GDPo-28 = $0,412, \operatorname{GDP} 21-49=0,422 \mathrm{~kg})$

$\mathrm{Na}$ ultima semana da fase pré-inicial, 42 a 49 dias, as dietas contendo $14,4 \%$ ou $9,6 \%$ do sucedáneo de leite em pó na ração resultaram em maior GDP $(P \leq 0,05)$ do que as dietas que contavam com o sucedáneo de leite diluido a $10 \%$ em água, 0,413 versus $0,367 \mathrm{~kg} /$ dia. A Figura 04 ilustra esses dados.

Considerando toda a fase pré-inicial de 21 a 49 dias, observa-se que os tratamentos contendo maior nivel de sucedâneo de leite em pó na ração, apresentaram GDP superior ao menor nivel, 0,250 versus $0,219 \mathrm{~kg} \quad(P \leq 0,04)$, qualquer que fosse a forma da ração, como ilustra a Figura 05.

Na fase inicial e considerando o periodo total não houve diferenças significativas entre os tratamentos $(P \geq 0,05)$.

Com o aumento de proteina lactea na dieta de leitôs, quer na forma de leite desnatado em pó, soro de 
62.

leite ou qualquer sucedáneo, geralmente verifica-se um aumento gradual no GDP. JUNQUEIRA \& ARAUJO (1986) obtiveram GDP crescentes quando o soro teve sua participação aumentada de 0 para $30 \%$ na dieta: GDPo-35 = 0,313 para $0,363 \mathrm{~kg}$, superior ao encontrado no presente estudo $(0,190$

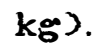

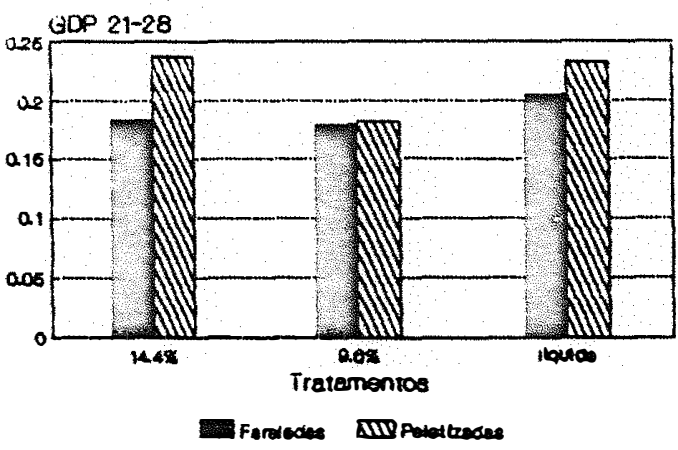

(A)

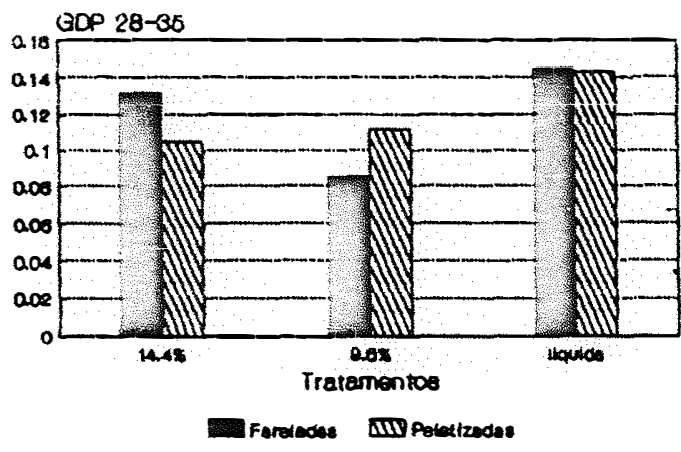

(B)

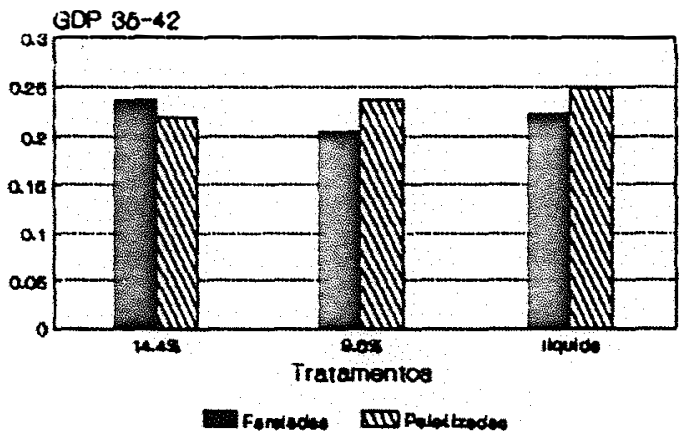

(G)

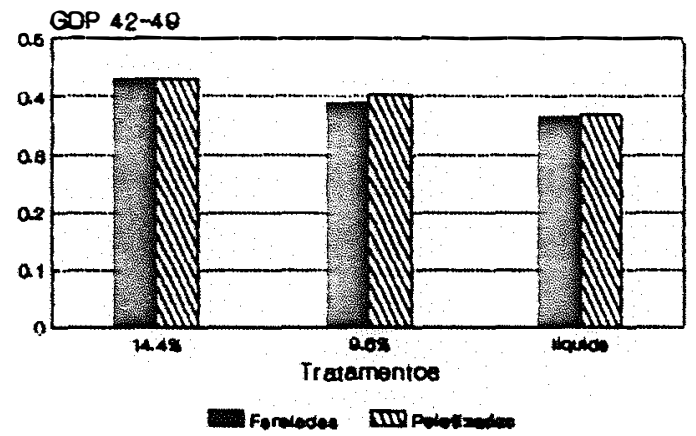

(D)

Figura 04 - Efeito das dietas seca crarelada e peletizada) e liquida no GDP nas quatro semanas da fase pré-inicial, 21-28 (A), $28-35$ (B), 35-42 (C) e 12-49 dias (D) 
63.

GDP PI

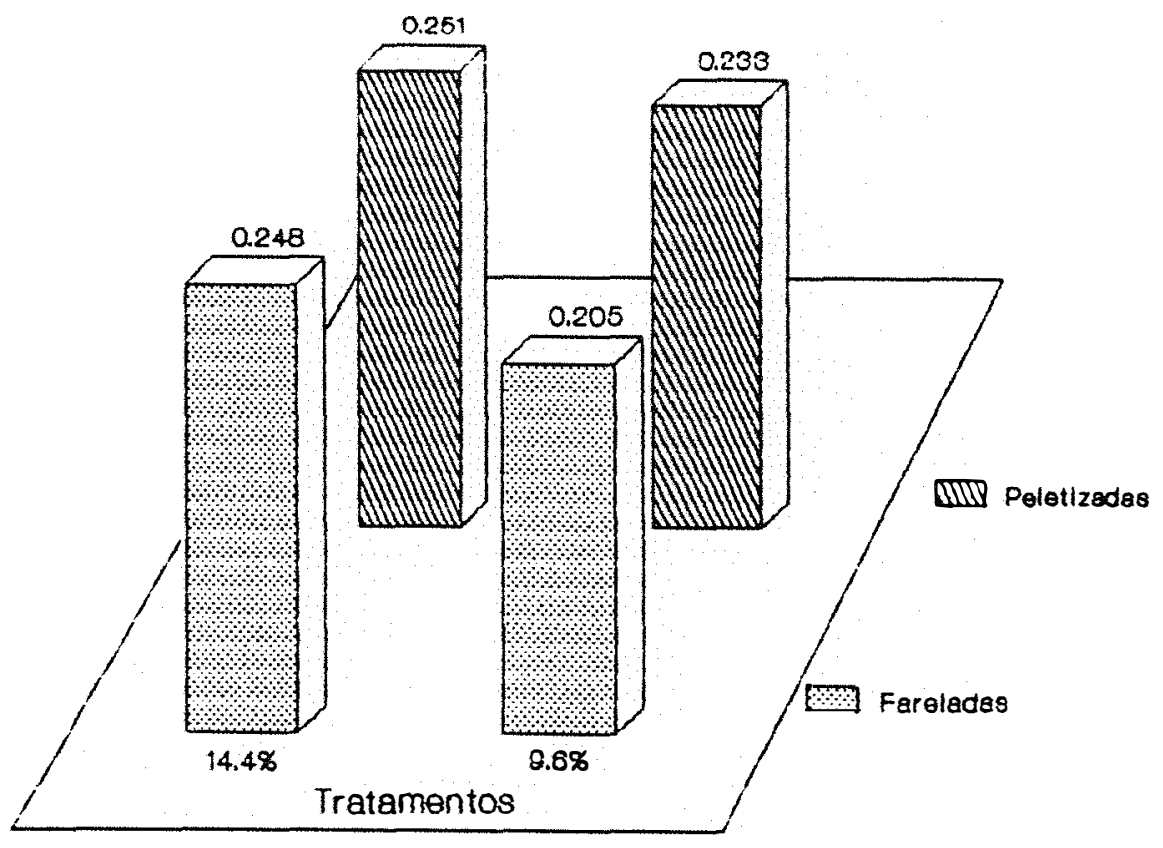

Figura 05 - Efeito do nivel de inclusão de leite nas raçótes pré-iniciais, no GDP.

De maneira geral, o desempenho dos leitzes ate a idade de desmame foi superior a muitos dos dados de literatura, embora alguns desses últimos tenham sido obtidos a partir de condições de criação artificial. Os dados desse trabalho comparados com os de literatura, assim se comportaram: GDPo-14 $=0,204$ versus $0,180 \mathrm{~kg}$ (PETTIGREW et alii, 1977), 0,147 com proteina de clara de ovo e 0,215 a $0,236 \mathrm{k}$ \& com proteina de leite em pó (PETTIGREW \& HARMON, 1977); GDP2-10 $=0,210$ versus $0,162 \mathrm{~kg}$ (KNUDSON et alii, 1987); GDP7-22 = 0,234 versus $0,149 \mathrm{~kg}$ (RODRIGUEZ \& YOUNG, 1981); GDP1-28 $=0,209$ versus $0,158 \mathrm{~kg}$ (FERREIRA et alii, 
1988a); GDP $4-28_{4}=0,216$ versus $0,182 \mathrm{~kg}$ (FERREIRA et alii, 1988b); GDP14-28 $=0,215$ versus 0,095 (LANDELL et alii, $1985 \mathrm{a}$ ), 0,215 versus $0,078 \mathrm{~kg}$ (LANDELL et alii, 1985b).

Situação oposta ocorreu após o desmame. Na maioria dos trabalhos revisados, a idade de desmame está entre 2 e 5 dias onde diversas hipoteses são testadas para o melhor desempenho dos leit.ర̃es paralelamente a maior economicidade e aumento da produtividade da porca. Tem-se como valores comparativos: GDPo-95 $=0,190$ versus $0,339 \mathrm{~kg}$ (JUNQUEIRA $\&$ ARAUJO, 1986); GDP14-95 $=0,181$ versus $0,340 \mathrm{~kg}$ (JONES et alii, 1977) e como exceçơes, 0,181 versus $0,157 \mathrm{k} \%$ (LANDELL et alii, 1985a) e 0,181 versus $0,125 \mathrm{~kg}$ (LANDELL et alii, 1985b); GDP21-95 $=0,157$ versus $0,203 \mathrm{~kg}$ (Etheridge et alii, citados por TARDIN, 1985), 0,248 $\mathrm{k} \%$ (RODRIGUEZ \& YOUNG, 1981); GDP28-35 $=0,112$ versus $0,378 \mathrm{~kg}$ (DECUYPERE et alii, 1981), 0,221 kE (LANDELL et alii, 1985b); GDP1-42 $=0,195$ versus $0,204 \mathrm{~kg}$ (FERREIRA et alii, 1988a); (GDP12-42 $=0,193$ versus $0,351 \mathrm{~kg}$ (DECUYPERE et alii, 1981); GDP28-42 $=0,169$ versus $0,300 \mathrm{~kg}$ (FERREIRA et alii, 1988a); GDP35-42 $=0,225$ versus $0,470 \mathrm{~kg}$ (DECUYPERE et alii, 1981), 0,440 $\mathrm{k}$ (JUNQUEIRA \& ARAUJO, 1986); GDP21-49 =0,236 versus 0,394

4.ETHERIDGE, R.D..; SEERLEY, R.W.; WIATT, R.D. The effect of diet on performance, digestibility, blood composition and internal microflora of weaned pigs. Journal of Animal Science, 58: 1396, 1984. 
kळ (LEIBBRANDT \& KEMP, $19 \dot{87}$ ).

Os resultados inferiores podem ser atribuidos a

alguns fatores como, menor consumo de $M S$, o que será discutido mais adiante, ocorrência de diarréias de origem alimentar nos tratamentos com a dieta líquida, além do estresse sofrido pelo desmame, que embora não fosse em idade precoce, demonstrava problemas também em leitơes fora do experimento.

\subsubsection{Consumo DiáRIO de RAÇÃo}

Os dados semanais dos consumos de ração seca de 21 a 61 dias e de dieta liquida durante a fase pré-inicial, de 21 a 49 dias, encontram-se, respectivamente, nos Apêndices 05 e 06. Os valores calculados para consumo diário de ração (CDR) nas fases estudadas estão no Apêndice 08. Para os tratamentos T5 e To, os dados de CDR já incluem o consumo de dieta líquida, calculado como sendo $10 \%$ da quantidade total em litros.

Os resultados de CDR podem ser observados na Tabela 09, onde foi adotado o mesmo procedimento já mencionado para a variável GDP e a Fiøura 06 mostra apenas as médias das fases pré-inicial, inicial e periodo total.

Nos Apêndices 21 a 27 , constam os quadros da
análise de variáncia para cada periodo apresentado na
Tabela 09. 
Tabela 09 - Médias de consumo diário de ração, ajustadas para o mesmo peso médio inicial, referente a cada periodo, em $\mathrm{kg}$.

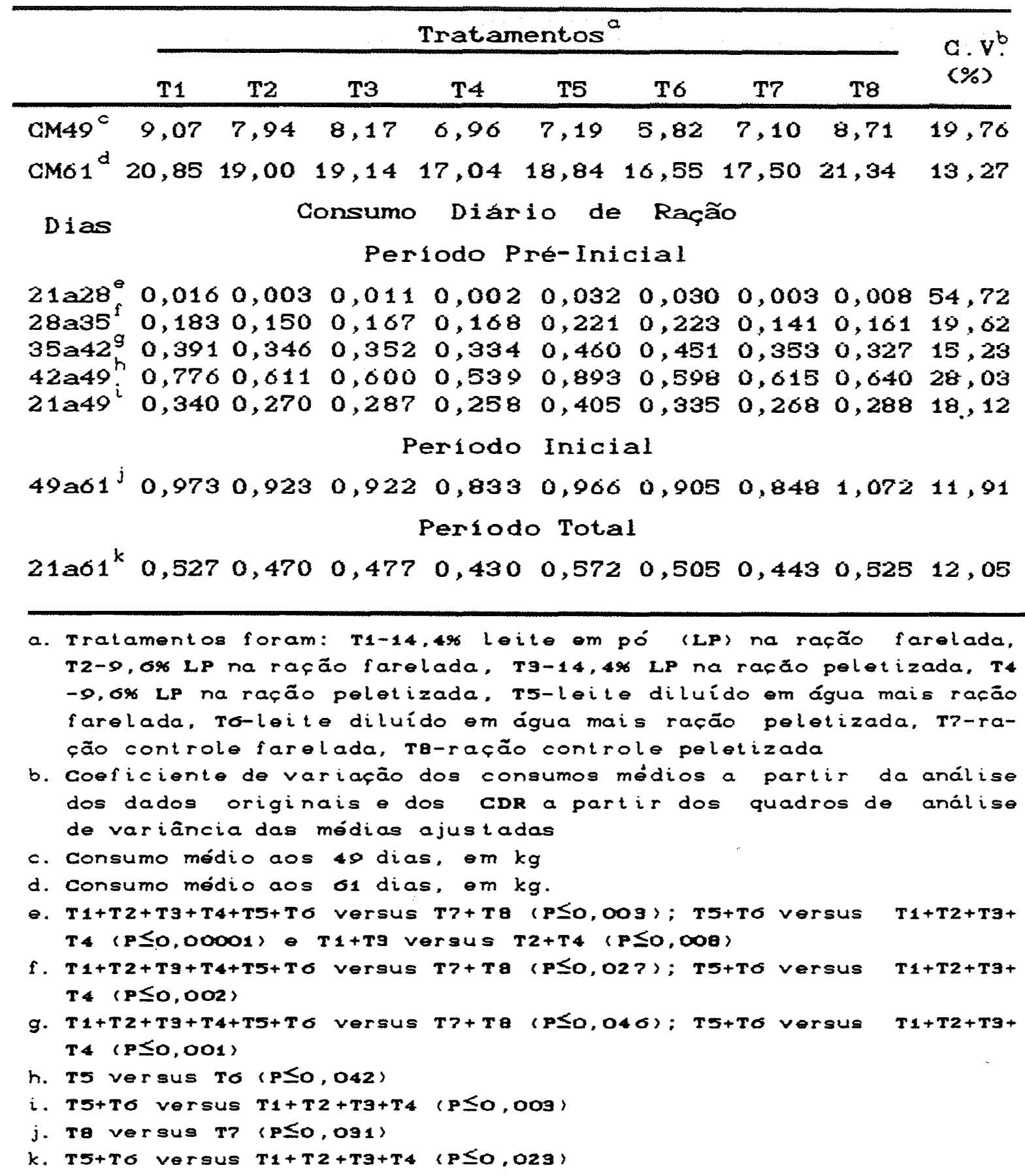




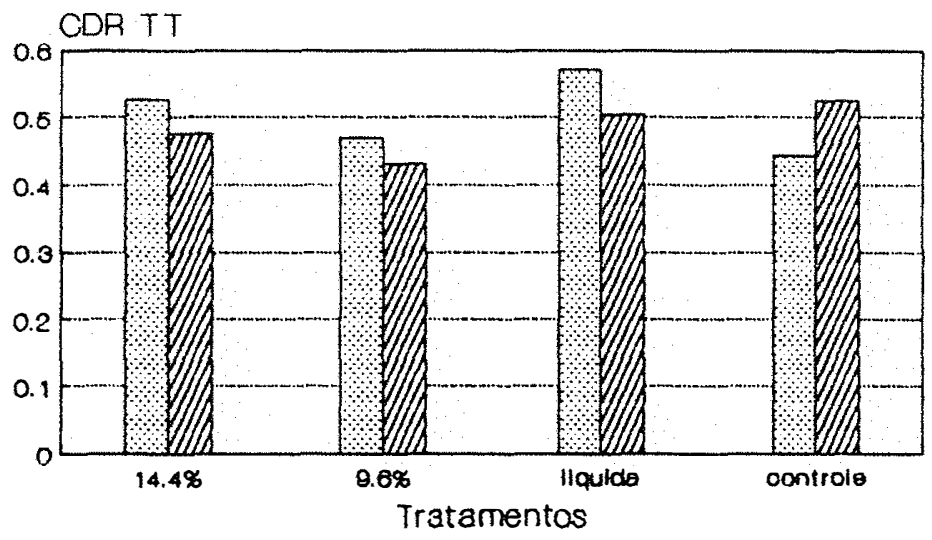

Fareledes 2 WED Peletizedas

(A)

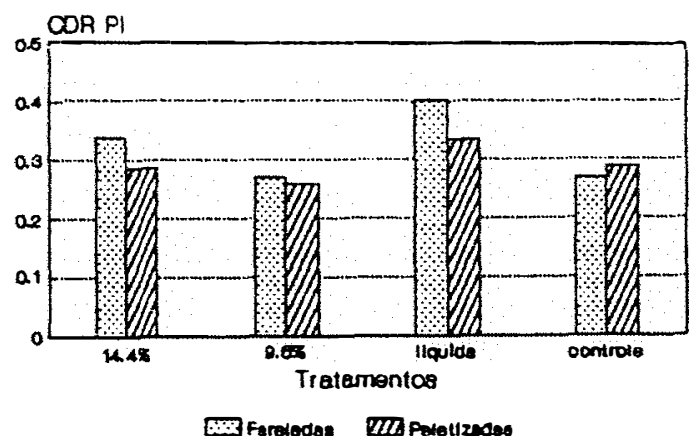

(B)

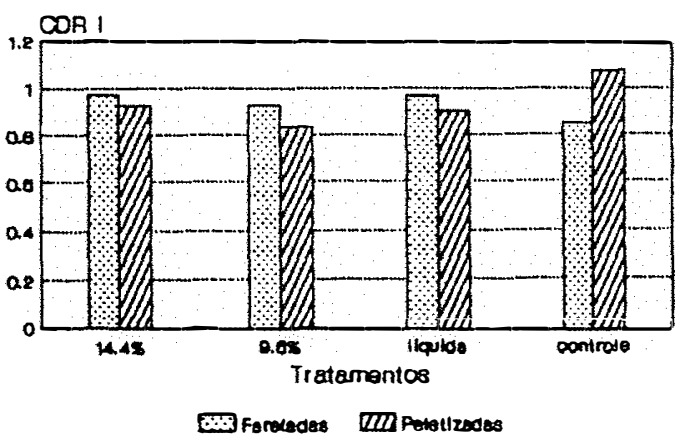

(C)

Figura o6 - Efeito da peletização no CDR, no periodo total (A), fiases pre-inicial (B) e inicial (C).

Resumidamente, com base na análise estatistica, os resultados de CDF podem ser avaliados (interpretados) com o auxilio do Quadro 01. 
Quadro 01 - Interpretação dos resultados de CDR a partir da análise estatistica.

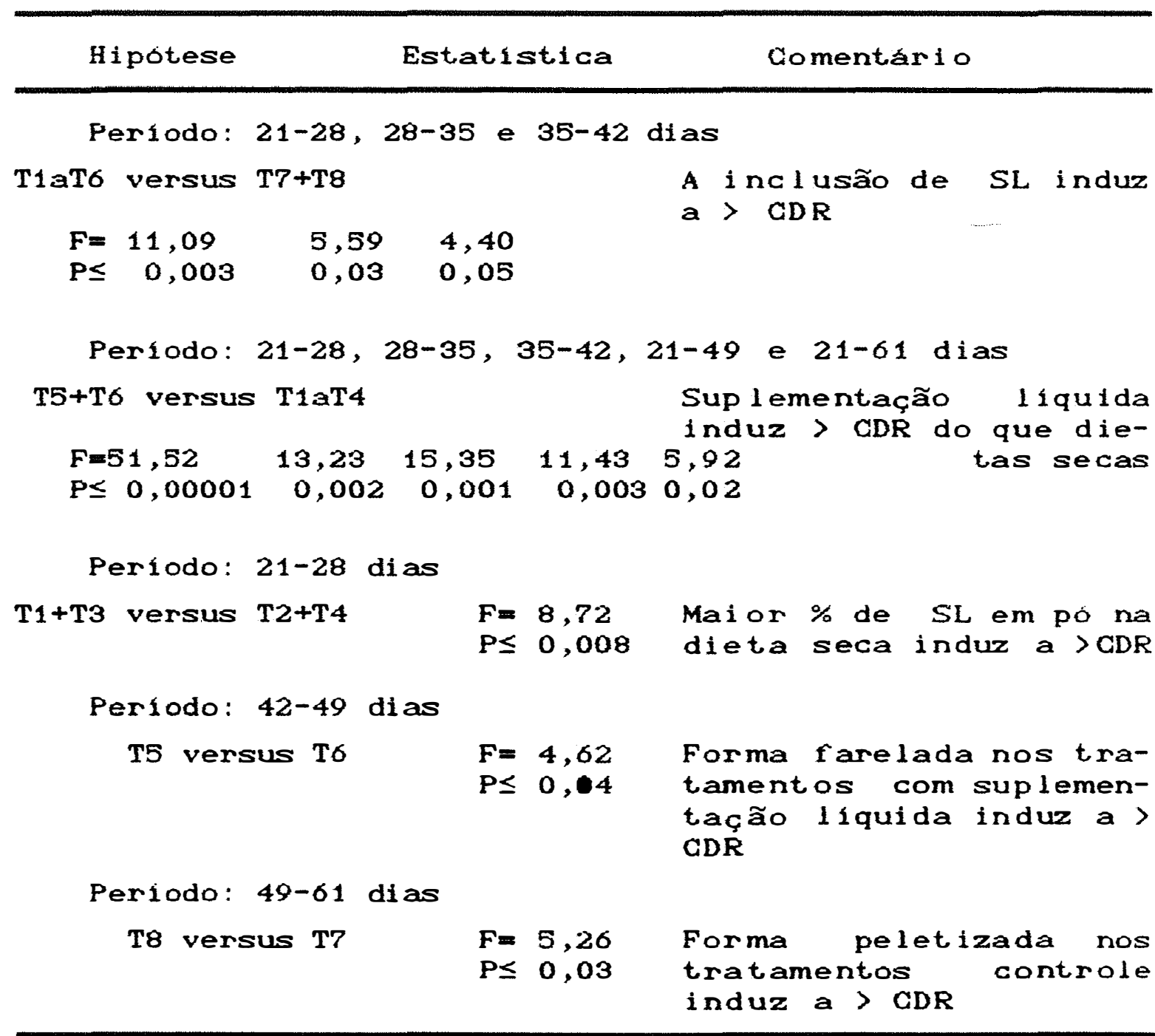

\begin{abstract}
As análises estatisticas revelaram contrastes
CT1aT6 versus $\mathrm{T} 7+\mathrm{T} 8, \mathrm{~T} 5+\mathrm{T} 6$ versus $\mathrm{T} 1 \mathrm{TT} 4$ e $\mathrm{T} 1+\mathrm{T} 3$ versus

T2+T4) significativos ( $\leq \leq 0,008)$ na primeira semana da

administração dos tratamentos. No entanto, essa fase (21-28

dias), ainda anterior ao desmame, deve ser avaliada com

critério. o CDR médio nessa fase é bastante pequeno, cerca de $13 \mathrm{~g}$; os tratamentos $\mathrm{T} 5$ e $\mathrm{T} 6$ proporcionaram consumos
\end{abstract}


elevados, exatamente devido a dieta liquida responsável por 84 e $77 \%$ do consumo total nos respectivos tratamentos; o coeficiente de variação verificado foi muito alto $(54,72 \%)$. Além disso, o consumo de leite materno não foi monitorado e - ajuste por covariáncia para $O$ PM aos 21 dias não se mostrou eficiente $(E \$ 96 \%)$. Portanto, quando se observa que - GDR foi superior nos tratamentos contendo SL, dentre estes maior para as dietas liquidas, e entre as dietas em pó, maior para o nível mais alto de SL, deve-se lembrar os itens mencionados acima.

Nas primeira e segunda semanas pós-desmame (28-35 e 35-42 dias), as dietas que continham SL apresentaram maior GDR e, dentre estas, as com suplementação liquida foram superiores à raçōes secas, como se observa na Figura 07 .

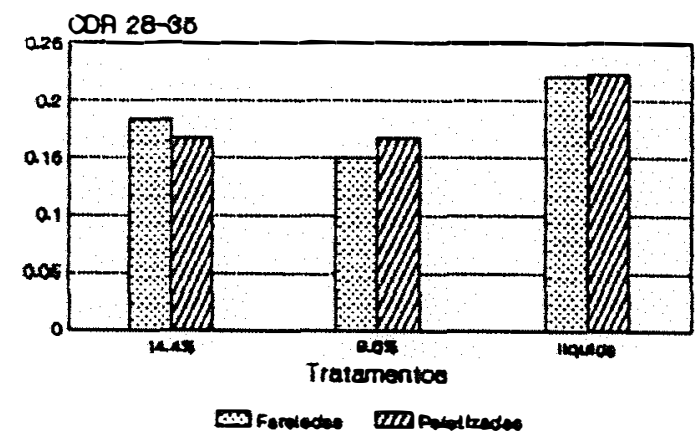

(A)

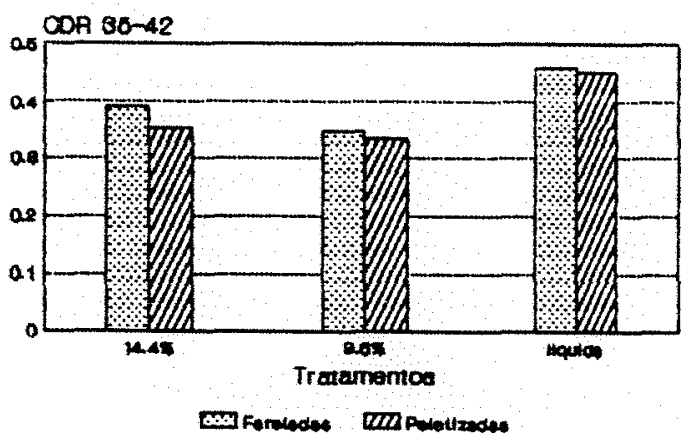

(B)

Figura 07 - Efeito das dietas no CDR, nes semanas de 28-35 (A) $e 35-42$ (B) dias. 
Leitช̃es desmamados frequientemente perdem peso ou tèm o ganho reduzido durante os primeiros 7-14 dias pósdesmame, quando este ocorre entre 2 e 4 semanas (LECGE et alii, 1979; LEIBBRANDT \& KEMP, 1987 e VARGAS, 1987). Tem-se demonstrado que se minimamente estressados, os leitóes criados artificialmente tem GDP, entre 3-5 semanas, equivalentes a leitశes lactentes, quando alimentados de hora em hora com dietas liquidas contendo cerca de $11 \%$ de calorias provenientes de proteina de soja (15\% do total de MS). Portanto, o pobre desempenho provavelmente reflete mais um manejo deficiente do que consequéncias inevitáveis de um desmame precoce. Sistemas de alimentação que apresentem alimento na forma liquida, como suplemento a dietas pré-iniciais oferecidas na forma seca, são alternativas para superar a depressão pós-desmame. A idéia básica desse sistema é a redução do estresse nutricional a um minimo, oferecendo ao leitão uma dieta liquida de alta qualidade nutritiva, juntamente com a dieta sólida que será consumida posteriormente (VARGAS, 1987).

Estudos feitos na Universidade de Wisconsin, em 1985, nos EUA, segundo VARGAS (1987) e LEIBBRANDT \& KEMP (1987), mostraram que os leitőes eram capazes de continuar com uma alimentação normal após o desmame, desde que a dieta apresentada a eles fosse numa forma familiar. Mostraram também que os leitốes não consomem energia adequada para manter seu PV durante os primeiros 4 dias 
pós-desmame. Durante esse periodo os leitőes se utilizam de suas reservas energéticas e, consequentemente, t.em seu desenvolvimento prejudicado. Com o aumento no consumo de MS, obteve-se um aumento do peso corporal cerca de 15,5 a $19,1 \%$ aos 56 dias de idade e isso é, particularmente, atrativo para o produtor de leitão que vende seus animais nesta data. Porem se essa vantagem beneficia, economicamente, os produtores de ciclo completo não é sabido.

Estudos feitos com leitões desmamados aos 21 dias mostraram que o CDR no primeiro dia pós-desmame com dietas liquidas foi de $0,286 \mathrm{~kg}$, enquanto que se alimentados unicamente com dietas sollidas haviam consumido apenas 0,135 $\mathrm{kg}$. Ao quinto dia de ensaio, quando a dieta liquida foi retirada o CDR havia sido, em média, $0,247 \mathrm{~kg}$ de $M S$, enquanto que no grupo controle foi de $0,163 \mathrm{~kg} / \mathrm{dia}$ (LEIBBRANDT \& KEMP, 1987 e VARGAS, 1987). Esses valores são comparáveis aos obtidos no presente estudo, embora o CDR com as dietas liquidas tenha sido um pouco inferior $(0,222$ $\mathrm{kg} / \mathrm{dia}$ com dietas liquidas e $0,167 \mathrm{~kg} / \mathrm{dia}$ com dietas secas contendo SL). No trabalho conduzido em wisconsin a diferença de peso final obtida foi atribuida exclusivamente ao maior consumo de MS. Do total de MS consumida pelos leitões tratados com dieta liquida, a maior porcentagem era devido ao consumo de ração liquida. Talvez essa mesma tendência não tenha se verificado no presente estudo, como 
llustra a Figura 07 , porque o fornecimento das dietas liquidas não foi realmente ad libitum. Mesmo assim, o consumo em termos de MS foi equivalente ao das dietas secas.

o aumento do consumo em relação às dietas secas não continuou a ocorrer na terceira semana pós-desmame (42-49 dias). Nessa idade, não se verifica mais a imaturidade do sistema digestivo, além de já terem vencido a dificuldade inicial de se adaptarem a mudança das 16 refeições diárias (amamentações) para uma ração sólida. o que se verificou foi um maior $\mathrm{CDR}$ da ração farelada em relação à peletizada nos tratamentos com suplementação de dieta liquida $(P \leq 0,04)$. Na verdade, com as raçós peletizadas observou-se um menor GDR em todas as fases estudadas e em todos os tratamentos, com algumas exceções, como verificado no grupo controle, observado na Figura 06.

Na fase inicial (49-61 dias), não houve diferença significativa $(P \leq 0,05)$ entre os tratamentos, exceto para o tratamento controle, onde a forma peletizada apresentou maior CDR do que a forma farelada. Embora o ajuste por covariăncia para mesmo $\mathrm{PM}$ aos 49 dias não tenha se mostrado eficiente $(E=97 \%)$, deve-se considerar que os pesos desses dois grupos representavam exatamente os pontos extremos da amplitude do $P M$ aos 49 dias, 14,51 e $10,81 \mathrm{~kg}$, respectivamente.

Onde as dietas liquidas são usadas, deve-se ter 
muito cuidado ao comparar valores de CDR por diferentes centros de pesquisa, uma vez que podem ocorrer diferenças no manejo adotado. A grande maioria buscando uma criação artificial tem desmamado os leitões ao redor de 2 dias de idade. Diferenças nas concentrações da dieta liquida também devem ser consideradas para comparação de resultados. Dessa mesma forma, há a dificuldade em comparar as taxas de crescimento que serão influenciadas pelas diferenças de consumos de alimento e de MS e também devido ao manejo. Diferenças entre raças também devem ser consideradas e poderiam ser responsáveis, no minimo, por parte das diferenças nas taxas de crescimento encontradas.

Mesmo com tais dificuldades, alguns dados são apresentados para efeito comparativo. NEWPORT (1977) afirmou que só é possivel ter máximo crescimento quando se fornece rações liquidas que contenham 15-20\% de MS que estimulam o aumento do consumo quando comparadas a mesma ração na forma de "pellets" secos. Ele obteve o consumo de ração nas três semanas pós-desmame $(7-28$ dias $)$ de $0,32 \mathrm{~kg}$ para a ração liquida e $3,59 \mathrm{~kg}$ para a ração seca. No presente trabalho obteve-se 10,35 e 7,99 kg/leitão para as dietas liquidas e secas, respectivamente. PETTIGREW et alii (1977b), trabalhando com proteina láctea a partir de leite peptonizado ou leite desnatado seco, observaram CDR2-10 = 0,600 e $0,104 \mathrm{~kg}$ para os respectivos produtos. Comparando tal resultado com o obtido nesse estudo nas 2 semanas pós- 
desmame tem-se $\operatorname{CDR28-42}=0,260 \mathrm{~kg}$ nos tratamentos com SL na ração (tratamentos $T 1$ a $T 4$ ). Os mesmos autores registraram $\mathrm{CDR}_{2-13}=0,169 \mathrm{k}$, trabalhando com leite desnatado e $0,157 \mathrm{k}$ o com caseina mais soro (PETTIGREW et alii, 1977a), equivalente aos $0,164 \mathrm{~kg}$ obtido neste estudo na primeira semana pós-desmame (28-35 dias). Os CDR registrados neste trabalho foram inferiores aqueles obtidos por LECGE et alii (1979), GDRo-22 = 0,160 e CDR27-42 = $0,770 \mathrm{~kg}$.

o que é concordante na maioria dos trabalhos é que leitôes com dietas liquidas ad ibitum crescem mais rapidamente do que quando alimentados 3 vezes ao dia e restritos a uma quantidade diária de dieta liquida equivalente a 30 ou $34 \%$ do $\mathrm{PV}$, ou com a mesma dieta na forma de "pellets" secos. Com esse sistema de manejo aumenta a ingestão de MS na primeira semana pós-desmame, fazendo com que não seja ignorada a lei fundamental da nutrição "o leitão que não come não pode ganhar peso ".

\subsubsection{Conversão Alimentar}

Os dados calculados de conversão alimentar (GA) individuais para as unidades experimentais, para as fases pré-inicial, inicial e periodo total estão no Apendica 09.

Os resultados médios de $\mathrm{CA}$ podem ser observados na Tabela 10 com a discriminação semanal da fase pré-inicial e 
a Figura 09 ilustra os valores médios nos tres periodos considerados. Como o desmame foi feito aos 28 dias, só a partir dessa data é que os dados de CA foram considerados.

Tabela 10 - Médias de conversão alimentar ajustadas para o mesmo peso médio inicial, em cada periodo.

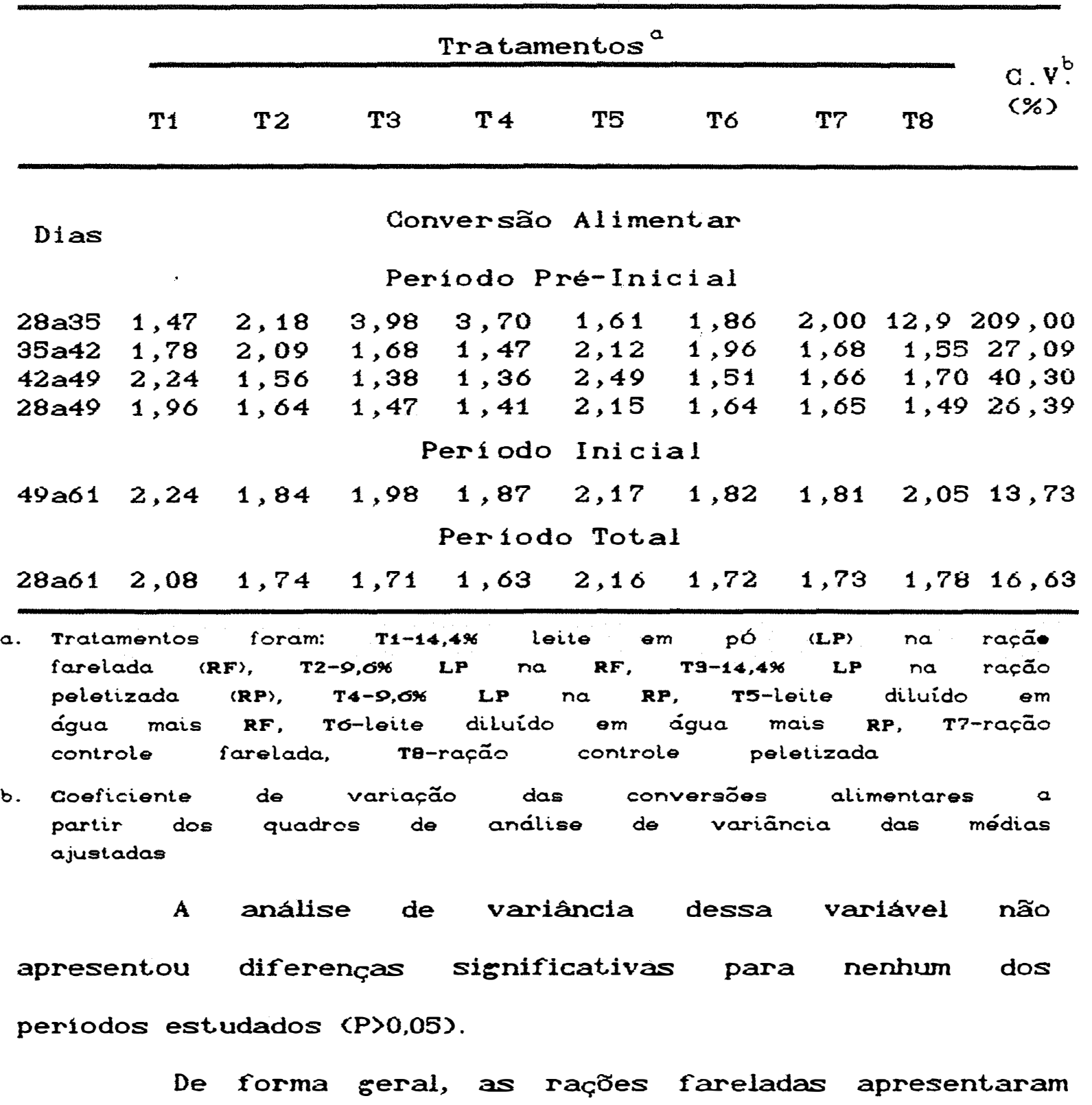


tendencia de $\mathrm{CA}$ inferiores, embora com diferenças não significativas $(P \geq 0,11)$, essa tendencia se mostrou mais evidente nas raçôes contendo 14,4 ou $9,6 \%$ de leite, que apresentaram $\mathrm{CA}$ pior do que as peletizadas: 1,80 versus 1,44 $(P \leq 0,11)$. Nas dietas com suplementação liquida, a tendéncia de una pior $\mathrm{GA}$ com as raçôs fareladas foi ainda mais acentuada, 2,15 versus $1,64 \quad(P \leq 0,11), 2,17$ versus 1,82 $(P \leq 0,07)$ e 2,16 versus $1,72 \quad(P \leq 0,053)$ para as fases pré-inicial, inicial e periodo total respectivamente.

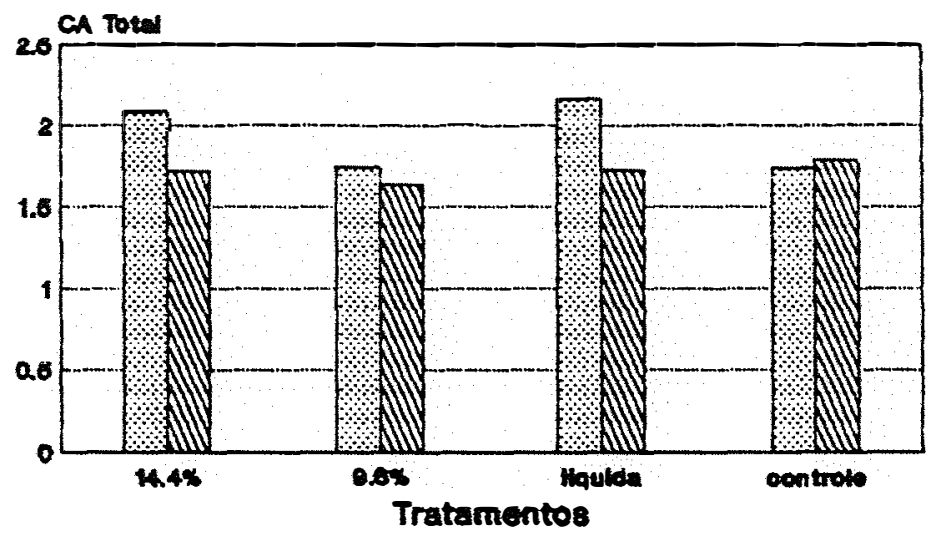

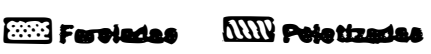

(A)

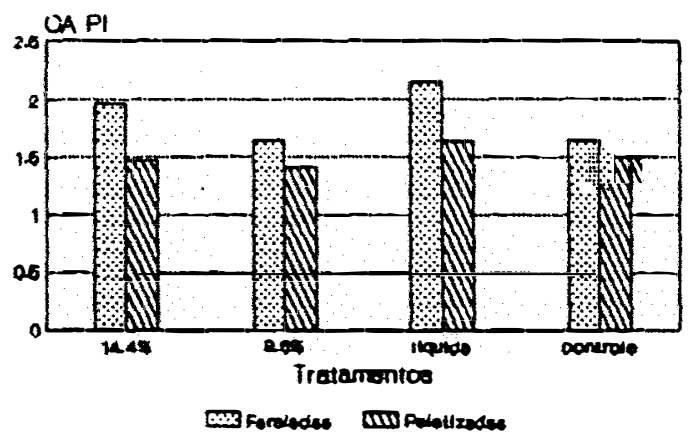

(B)

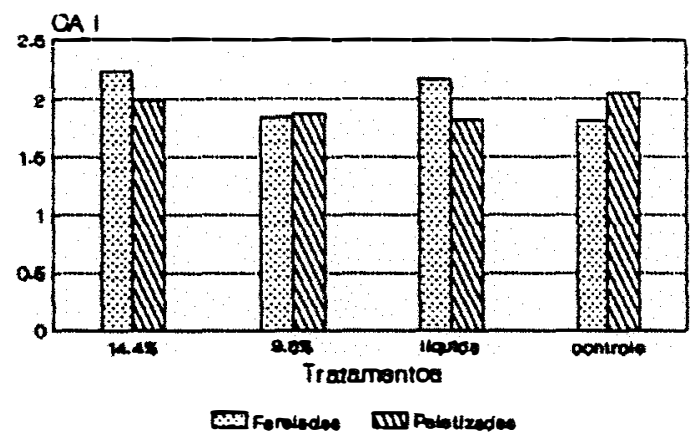

(C)

Figura 08 - Conversão alimentar de leitơes no periodo total (A) e nas fases pré-inicial (B) e inicial (C). 
No periodo de 49 a 61 dias as rações com maior nivel de leite proporcionaram pior $\mathrm{CA}(2,11)$ do que aquelas que continham menor nivel $(1,85)$ com $P \leq 0,07$.

BRAUDE \& NEWPORT (1971), trabalhando com diferentes fontes de gordura em substituição ao leite integral obtiveram $\mathrm{CAz}-\mathrm{z}=0,59$ e $\mathrm{CAz-20}=0,82$ para leite integral, com leitões desmamados aos dois dias de idade. Posteriormente, outros pesquisadores obtiveram resultados concordantes com os de BRAUDE \& NEWPORT (1971), mostrando que os leitões podem ganhar mais de 15 PV para cada of de MS consumida CCOALSON \& LECGE, 1973; PETTIGREW \& HARMON, 1977; PETTIGREW et alii, 1977 a e PETTIGREW et alii, 19977b).

BRAUDE et alii (1970), avaliando o valor nutritivo do leite em função do processamento pelo calor, obtiveram GA2-28 $=2,32$ com o tratamento severo e 1,13 com o tratamento brando. POND et alii (1971), comparando concentrado protéico de peixe com caseina e proteina isolada de soja em dietas liquidas, obtiveram CAz-29 = 1,35 para a dieta com concentrado de peixe e GA2-29 $=1,45$ com caseina. Esses resultados não concordam com a afirmação acima, mas são comparáveis aos valores obtidos de 3 semanas após o desmame, no presente estudo, GA28-4s =1,67 em média, com os melhores resultados obtidos nos tratamentos T3 $(1,47)$ e T4 $(1,41)$.

o que se conclui é que a utilização de dietas liquidas após o desmame melhora o desempenho mas piora a 
CiA e também aumenta o trabalho $e$ as despesas. Sua utilização apenas na primeira semana pós-desmame e com uma administração de quantidades reduzidas progressivamente cad libitum no primeiro dia, essa mesma quantidade no segundo, $50 \%$ nos terceiro e quarto dias) parece ser uma boa opção económica, como indicado pelo trabalho de Wisconsin.

o fornecimento da dieta liquida exige um manejo cuidadosso. 0 ambiente quente da instalação pode favorecer o crescimento microbiano num sucedáneo de leite rico em nutrientes, logo comedouros e equipamentos devem ser limpos todos os dias. Além disso, uma nova solução com sucedâneo deve ser preparada a cada dia.

\title{
4.2. ImUnoglobulinas SÉricas
}

\begin{abstract}
Os resultados individuais das determinaçôes séricas de imunoglobulinas (Ig) por tratamento, obtidas em laboratório, podem ser observados nos Apéndices 12 a 15 . 0 Apêndice 16 traz a média dos valores obtidos nos blocos e também a média seral.
\end{abstract}

$$
\text { Os niveis médios de Ig séricas de leitres }
$$
submetidos aos tratamentos T3, T4, T6 e T8 são apresentados na Tabela 11, em unidades ZST, salientando que as coletas de sangue foram realizadas apenas nas unidades que receberam as dietas peletizadas, conforme já descrito na 
metodologia.

Tabela 11 - Médias dos valores de imunoglobulinas sericas, em unidades ZST, dos animais submetidos aos tratamentos T3, T4, T6 e T8.

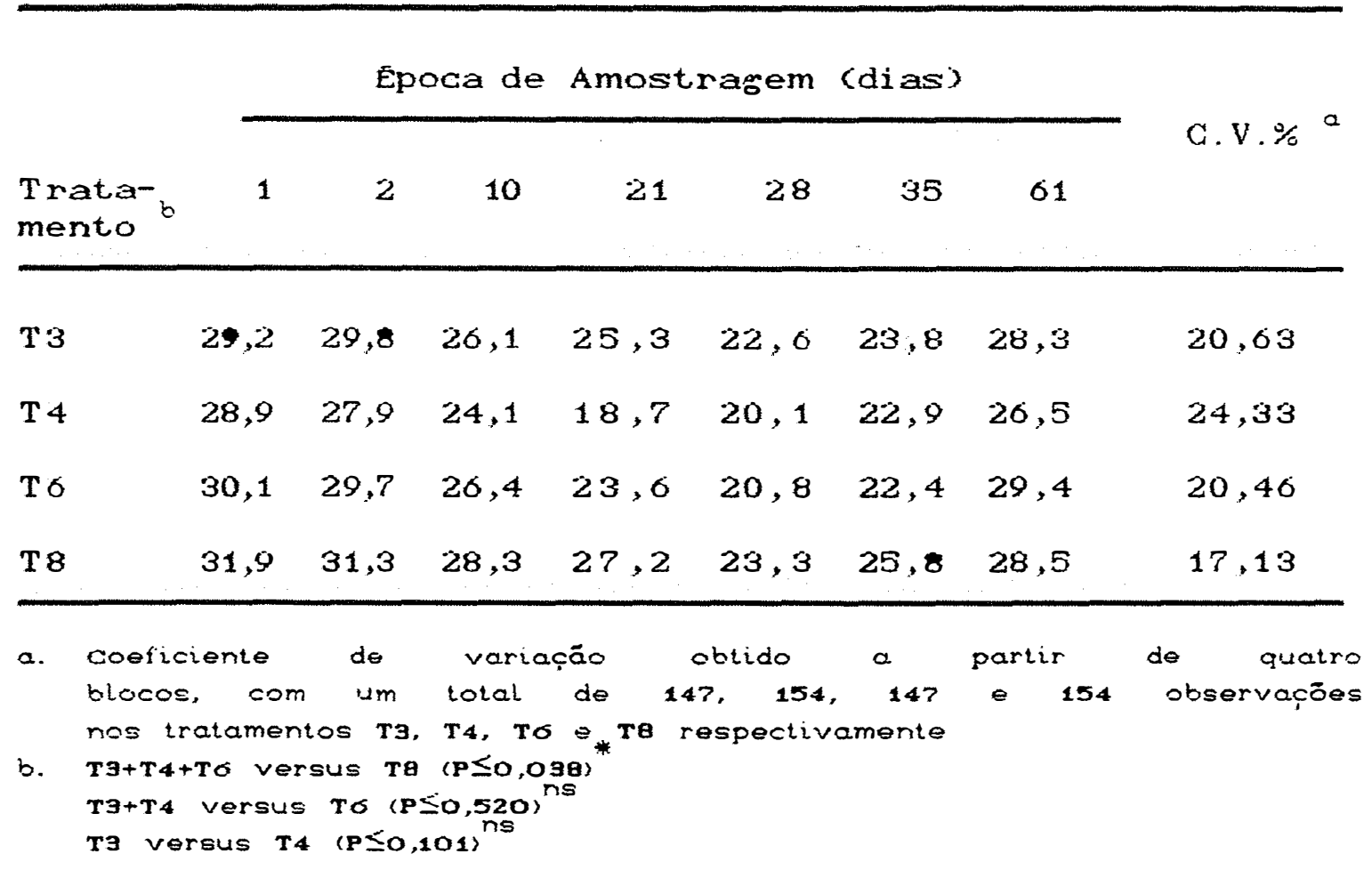

A Fioura 09 ilustra a flutuação de lo serica (unidades ZST), segundo os dados medios originais de laboratorio.

A análise de variancia inicial dos resultados revelou um contraste significativo diferenciando o tratamento controle (T8) dos demais (T3+T4+T 6 ) quante ao perfil imunológico de leitões representado pelos niveis de Is sérica, conforme ilustra o Quadro 02 ou, detalhadamente, 
no Apendice 28.

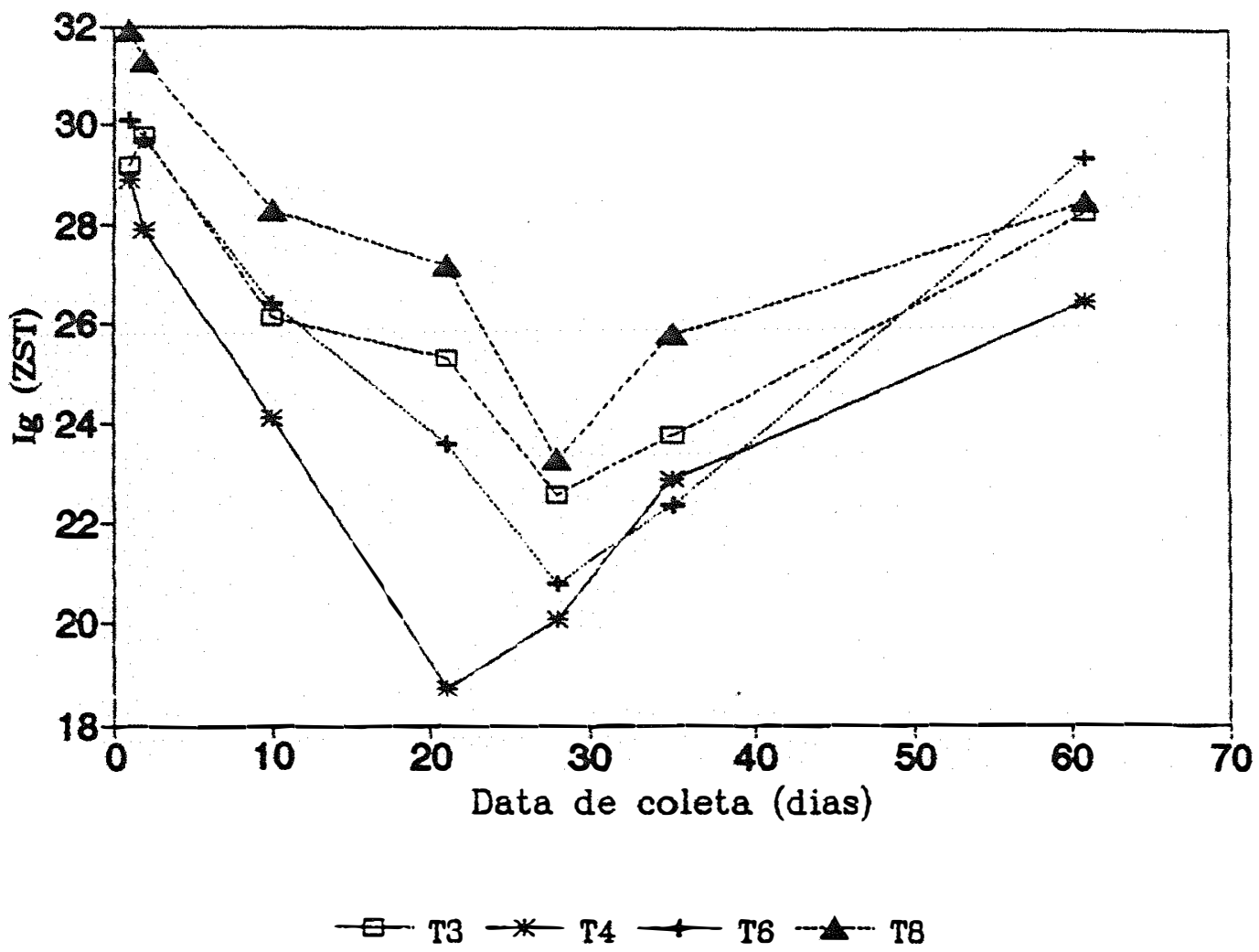

Figura 09 - Flutuação dos nivels de Ig sérica cunidades ZST), em leitơs.

Quadro 02 - Interpretação dos resultados de If́s serica a partir da analise estatistica, de 1-61 dias.

\begin{tabular}{|c|c|c|}
\hline Hipotese & Estatistica & Comentário \\
\hline Periodo: $1-61$ dias & & \\
\hline $\begin{array}{c}\mathrm{T} 8 \\
\text { versus } \\
\mathrm{T} 3+\mathrm{T} 4+\mathrm{T} 6\end{array}$ & $\begin{array}{l}F=5,77 \\
P \leq 0,04\end{array}$ & $\begin{array}{l}\text { A inclusão de } \text { SL na } \\
\text { dieta de leitões reduziu } \\
\text { o nivel de Is serica }\end{array}$ \\
\hline
\end{tabular}


81.

\begin{abstract}
Na tentativa de discriminar os periodos experimentais realizaram-se duas análises separadas, uma para o periodo de 1 a 28 dias e outra para 28 a 61 dias. 0 quadro 03 apresenta os resultados obtidos e os Apéndices 29 e 30 mostram a análise de variancia detalhada.
\end{abstract}

Quadro 03 - Interpretação dos resultados de I s serica a partir da análise estatistica, de 1-28 e de 2861 dias.

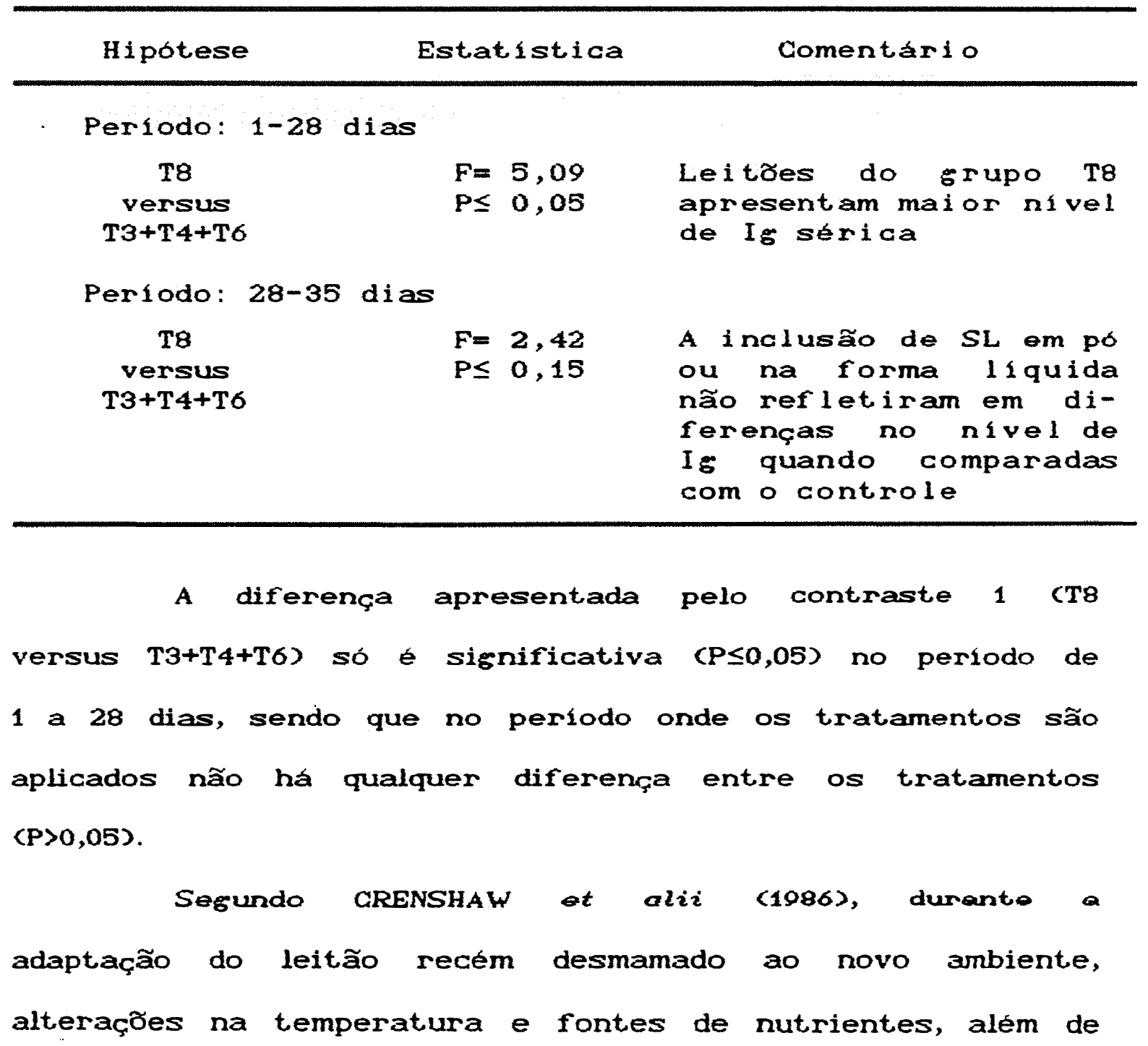


uma serie de outros fatores podem interagir com o "status" nutricional deficiente criado pela reduçäo de consumo alimentar $€$ predispor, assim, o leitäo à doença. No entanto, os fatores testados nos tratamentos, niveis e formas de sucedàneo de leite năo influenciaram $(P>0,05)$ no comportamento imunológico.

Quando os dados foram avaliados dentro de cada periodo de amostragem, atraves de contrastes, não foram observadas diferenças significativas, $\quad P \geq 0,60, \quad P \geq 0,52$, $P \geq 0,58, P \geq 0,09$ e $P \geq 0,51$ para as datas $1,2,10,21$ e 28 dias no primeiro periodo e $P \geq 0,31 \quad P \geq 0,19$ e $P \geq 0,52$ para. as datas 28,35 e 01 dias respectivamente ctem-se duas probabilidades para a data de 28 dias por essa ter sido considerada nos dois periodos). Atraves do teste de Tukey, comparando todo o periodo experimental, observa-se uma diferença significativa $(P \leq 0,01)$ entre os leitóes dos tratamentos $\mathrm{T} 4$ e T8 aos 21 dias, contirmando o que ja havia sido observado, conforme o Quadro 03. Embora os tratamentos tenham sido aplicados a partir dos 21 dias, como o desmame ocorreu aos 28 dias e considerando que nessa data não houve diferenças entre os tratamentos, pode-se estabelecer que não houve influència no perfil imunológico. Após as 24 horas, as relaçóes entre data de coleta (x) e unidades ZST (y), para todo o periodo experimental, de 1 a 01 dias e expressa pelo modelo matemático a seguir: 


$$
\begin{aligned}
& \text { onde } x=\text { datia de coleta (dias), } \\
& y=\text { Io (unidades } z S T \text { ), } \\
& y=30,4136-0,47634 x+0,007245 x^{2} \\
& \text { com } R^{2}=0,90 \\
& P \leq 0,00001
\end{aligned}
$$

A equação está representada abaixo na Figura 10.

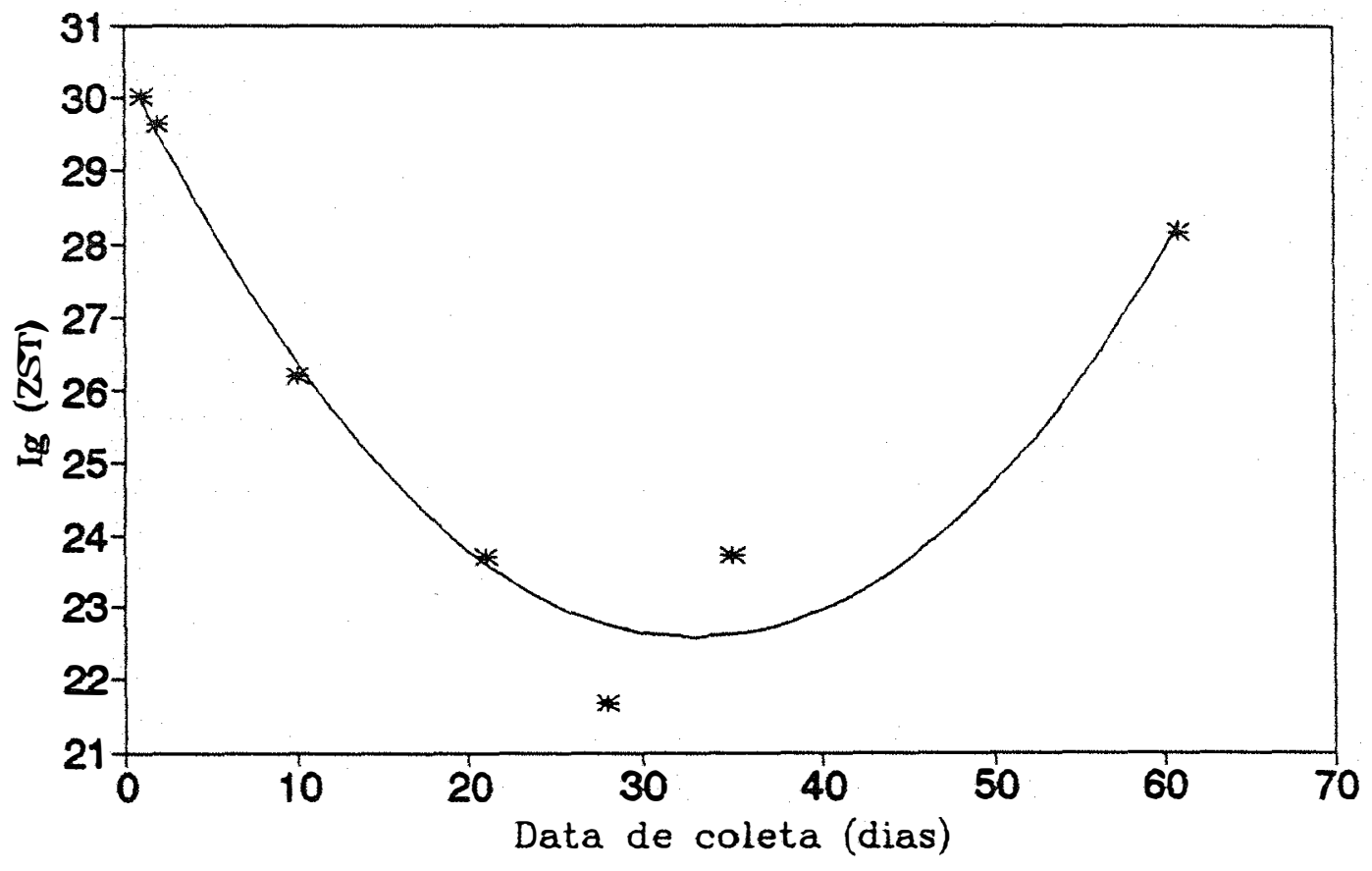

- Ajuste quadrático * Médias originais

Figura 10 - Regressão polinomial para a flutuação de niveis de Ig sérica, em leitốes de 1-61 dias.

As menores concentraçöes de Ios sérica observadas ocorreram entre 28-35 dias nos tratamentos $T 3, T 4$ e $T 6$ e 
entre 21-28 dias no tratamento $T 4$. Sendo a queda mais acentuada, no periodo de 1-28 dias, do que a elevação no periodo subsequente, o modelo matemático estimou a concentração minima aos 32,8 dias.

BROWN et alii (1961) observaram que os anticorpos adquiridos via colostro são detectáveis no soro de leitôes por até $\sigma$ semanas após o nascimento, sendo o nivel mais baixo aos 21 dias de idade. Injeçতes de bacterina iniciadas com 1 semana de idade só estimularam. produção de anticorpos a partir de 4 semamas de idade.

No trabalho de HAYE \& KORNEGAY (1979), as menores concentraç̧̃es de IgG, IgA e IgM ocorreram aos 30,15 e 10 dias de idade, respectivamente e mostram tambem que o desmame as 12 horas afetou apenas os nuveis de IoM mas não de IgG e IgA . Segundo BLECHA et alii (1983) o desmame influi na imunidade celular do leitão, quando praticado antes das 5 semanas de idade. Ocorre redução na resposta celular imune tanto in vivo como in vitro. No entanto, o(s) mecanismo(s) fisiológico e imunológico responsáveis pela deficiente imunidade celular por ocasião do desmame é desconhecido, embora várias hipóteses sejam aventadas, como glucocorticóides, cortisol, prostaglandinas, serotonina, alteraçoes neuroquimicas, etc.

E amplamente documentado que leit oes nascem essencialmente livres de anticorpos circulantes já que é pequena a transferéncia via placentária de Is materna para 
- feto. Portanto, a passagem de proteinas do colostro póaparto, da fémea para o recém-nascido é de importáncia critica. Garacteristicamente, a imunidade passiva do leitão, derivada do colostro da fémea, alcança o máximo 24-36 horas pós-parto e diminui logaritmicamente depois. Devido a isso, o leitão experimenta um periodo onde sua imunidade circulante (sistêmica) é perigosamente baixa, as três semanas de idade, antes que uma produção ativa de anticorpos ocorra CMLLER et alii, 1962; HAYE \& KORNEGAY, 1979, GRENSHAW et alii, 1986).

$\mathrm{Na}$ tentativa de discrimimar os periodos experimentais, o modelo (9) foi subdividido, resultando em novos modelos de regressão linear:

Para o periodo de 1 a 28 dias:

$\begin{array}{lcc}y=29,3617-0,31143 x & R^{2} & P \\ y=31,9287-0,28457 x & 98,15 & 0,00002\end{array}$

Para o periodo de 28 a 61 dias:

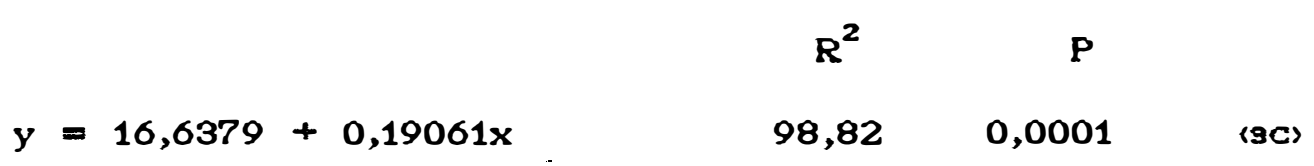

Para o primeiro periodo experimental, são apresentados os modelos (3A) e (3B) exatamente devido a 
diferença entre os grupos representados por $\mathrm{T} 3+\mathrm{T} 4+\mathrm{T} 6$ e T8. Na segunda fase, como não há diferença entre os tratamentos tem-se apenas uma equação média. Tais equaçð̃es são ilustradas, abaixo, na figura 11 (A) e (B).

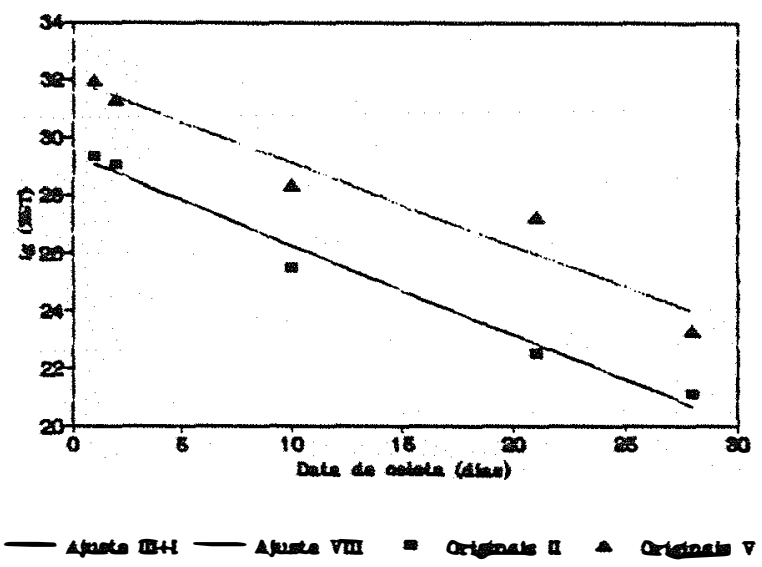

(A)

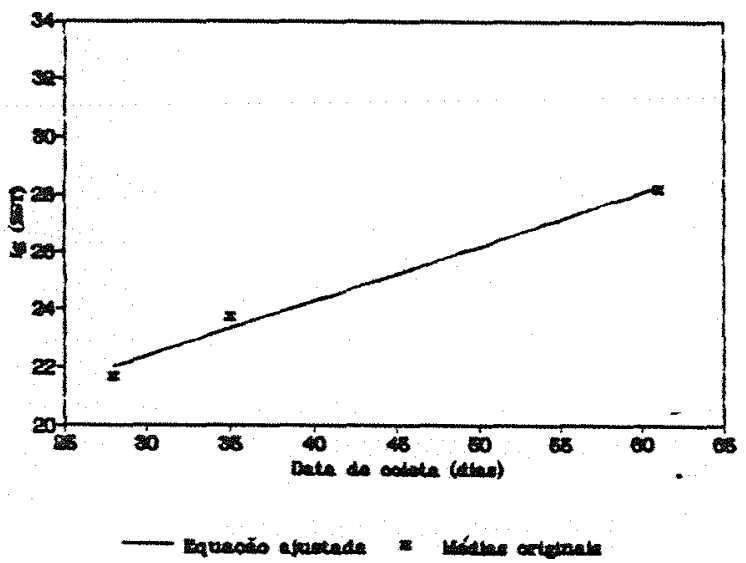

(B)

Figura 11 - Regressães polinomiais para a flutuação dos niveis de Ig sérica, em leitões de 1-28 (A) $e$ de 28-61 dias (B).

Os modelos para os dois periodos indicam uma queda média de 0,298 unidades ZST de Ig sérica por dia até $0 \simeq$ $33^{\circ}$ dia, ponto minimo estimado e um aumento de 0,191 unidades ZST de If sérica por dia até 061 o dia. Tais valores Indicam que aos $\simeq 33$ dias se inicia uma fase de aumento de Is numa taxa inferior ao decrescimo ocorrido na fase de catabolismo. Aos 01 dias os leitões apresentaram de 89-98\% da concentração máxima de Is sérica adquirida 
passivamente entre 24-48 horas de vida, mostrando que a fase de produção endógena de Is não havia rest.abelecido plenamente os niveis observados nas concentraçðes máximas.

$\mathrm{Na}$ média os leitठes apresentaram 30,0 unidades ZST com 1 dia de idade que declinou para 22,0 unidades ZST com 28 dias e tornou a se elevar aos 61 dias (fim do experimento) para 28,0 unidades ZST. Esses valores estimados através dà equação (1) descrita anteriormente, correspondem, respectivamente, as concentraçбes de $28,09 \mathrm{mg}$ $\mathrm{Ig} / \mathrm{ml}, 17,35 \mathrm{mg} \mathrm{Ig} / \mathrm{ml}$ e $25,40 \mathrm{mg} \mathrm{Ig} / \mathrm{ml}$ conforme a equação (1) descrita anteriormente no item 3.8 na metodologia.

Aos 61 dias, os leitóes já se encontravam com um nivel considerável de Ig sérica, sendo que as concentraçôes iniciais ( 1 e 2 dias) e final ( 61 dias) já não apresentavam diferenças significativas $(P>0,05)$. A figura 10 ilustra uma equação média para o comportamento imunológico dos leitðes apresentando esses pontos.

E provável que a alta concentração de Ig materna, presente na circulação dos leitões as 48 horas de idade, retarde o inicio da fase endógena de produção de anticorpos. A auséncia de uma maior taxa de acréscimo, após as datas (entre 21 e 35 dias) de menor concentração, pode representar a interação dos processos de catabolismo das Ig absorvidas e de produção endógena de Ig, de maneira que não foi possivel caracterizar o ponto de inflexão da curva e, consequentemente, 0 inicio da fase endogena no periodo 
observado.

A concentração de Ig foi superior nos leiţ̌es do tratamento T8 em relação ao tratamento $T 4(P \leq 0,01)$, aos 21 dias de idade, diferença essa, possivelmente, devido a Ig exógena, proveniente do colostro. A partir dal, época em que se caracteriza o inicio da fase de produção de Ig endógena, deixa de ocorrer tal diferença. Ainda é possivel observar que o coeficiente de variação foi menor no tratamento T8 $(17,13 \%)$ do que no tratamento T4 $(24,33 \%)$ Embora ambos sejam altos, indicam um maior número de variáveis envolvidas na fase endógena de produção de Iğ, que não foram controlados durante a fase experimental. Um maior número de coletas após a reversão da curva permitiria uma análise mais completa da fase endógena de produção de Ig. 


\title{
5. CONCLUSÕES
}

\begin{abstract}
A utilização de sucedâneo de leite em dietas préiniciais de leitơes após o desmame favoreceu um aumento no consumo de ração nas duas primeiras semanas pós-desmame. 0 seu fornecimento na forma liquida proporcionou um maior consumo em relação à adição na forma seca. Esse maior consumo de ração, obtido com a suplementação na forma liquida, levou a uma tendéncia de maior taxa de ganho diário de peso, na primeira semana pós-desmame, embora sem signnificância estatistica, enquanto que na terceira semana, - ganho diário de peso obtido com a suplementação líquida foi superado pelas raçōes secas contendo sucedâneo de leite.
\end{abstract}

Considerando toda a fase pré-inicial, niveis
maiores de inclusão de sucedâneo de leite a ração
proporcionaram taxas de crescimento mais rápidas.

$\mathrm{Na}$ fase inicial não se verificou aumento de consumo de ração nem diferenças no ganho diário de peso com as dietas com sucedâneo de leite. Também as dietas que anteriormente tinham uma suplementação liquida não 
apresentaram qualquer diferença em relaçäo às demais.

A conversão alimentar $e 0$ nivel serico de imunoglobulinas não foram afetados pela inclusão de sucedâneo de leite ás raçöes.

Embora sem significància estatística, as raçōes peletizadas tenderam a apresentar maiores ganhos de peso e menores consumos de ração.

Os resultados obtidos no present.e estudo indicaram que o empreso de sucedäneo de leite melhora a taxa de crescimento de leit.óes na fase pré-inicial e que sua ut.ilização na forma liquida na primeira semana pós-desmame pode favorecer o desempenho dos animais, estimulando um maior consumo de ração. Tal técnica favoreceria principalmente produtores de leitões. Novos estudos poderão indicar concentrações mais apropriadas de utilização do sucedàneo de leite na forma liquida levando-se em conta a sua retirada gradual ou näo $e$ os custos envolvidos com raçóes e equipamentos. Também ensaios com acompanhamento até o abate poderão avaliar melhor essa recomendaçăo para produtores de ciclo completo. 


\section{REFERẼNCIAS BIBLIOGRÁFICAS}

ARGENZIO, R.A. Digestão, absorção e metabolismo. In: Dukes - Fisiologia dos Animais Domésticos. 10 a Edição. Rio de Janeiro, Editora Guanabara, Swenson, M.J., 1988.

ASPLUND, J.M.; GRUMMER, R.H.; PHILLIPS, P.H Absorption of colostral gamma-globulins and insulin by the newborn pis. Journal of Animal Science, Champaign, 21: 412-3, 1962.

BLECHA, F.; POLLMANN, D.S.; NIGHOLS, D.A. Weaning pigs at an early age decreases cellular immunity. Iournal of Animal Science, Champaign, 56(2): 396-400, 1983.

BOURNE, F.J. Symposium on nutrition of the young farm animal - the immunoglobulin system of the suckling pig. Proceedinss of Nutrition Society, London, 32: 205-15, 1973.

BRAUDE, R. \& NEWPORT, M.J. Artificial rearing of pigs 4 * the replacement of butterfat in a whole-milk diet by either beef tallow, coconut oll or soya-bean oil. British Journal of Nutrition, London, 29(2): 447-55, 1973. 
BRAUDE, R. \& NEWPORT, M.J. A note on a comparison of two systems for rearing pigs weaned at, 2 days of age, involving either a liquid or a pelleted diet. Animal Production, Edinburgh, 24: 271-4, 1977.

BRAUDE, R.; KEAL, H.D.; NEWPORT, M.J. Artificial rearing of pigs 5 * the effect of different proportions of beef tallow or soya-bean oil and dried skim milk in the diet on growth, feed utilization, apparent, digestibility and carcass composition. British Journal of Nutrition, London, 35: 253-8, 1976.

BRAUDE, R.; NEWPORT, M.J.; PORTER, J.W.G. Artificial rearing of pigs 2 * the time course of milk protein digestion enzyme secretion in the 28-day-old pig. British Journal of Nutrition, London, 24(3): 827-42, 1970.

BRAUDE, R.; NEWPORT, M.J.; PORTER, J.W.G. Artificial rearing of pigs 3 * the effect of heat treatment on the value of spray-dried whole-milk powder for the baby pig. British Journal of Nutrition, London, 25: 113-25, 1971.

BREWER, J.M. \& ASHWORTH, R.B. Disc eletrophoresis. Journal of Chemical Education, Easton, 46: 41-5, 1969. 
BROWN, H.; SPEER, V.G.; QUINN, L.Y.; HAYS, V.M.; GATRON, D.V. Studies on colostrum-acquired immunity and active antibody production in baby pigs. Journal Animal Science, Ghampaign, 20: 323-8, 1961.

GAMPBELL, R.M.; BROUGH, H.; FELL, B.F. The development of some digestive enzymes in the intestines of pigs reared artificially. Iournal of Arricultural Science, Cambridge, 76: $531-8,1971$.

CATRON, D.V.; NELSON, L.F.; ASHTON, G.C.; MADDOCK, H.M. Development of practical synthetic milk formulas for baby pigs. Journal of Animal Science, Champaign, 12: $62-75,1953$

COALSON, J.A. \& LEGGE, J.G. Herd differences in the expression of fatal diarrhea in artificially reared piglets weaned after 12 hours vs 36 hours of nursing. Journal Animal Science, Champaign, 3066): 1114-21, 1973 a.

COALSON, J.A. \& LECGE, J.G. Influence of nursing intervals on changes in serum proteins $($ immunoglobulins $)$ in neonatal pigs. Journal of Animal Science, Champaign, 36(2): $381-5,19736$. 
CRENSHAW, T.D.; COOK, M.E.; ODLE, J.; MARTIN, R.E. Effect of nutritional status, age of weaning and room temperature on growth and systemic immune response of weaninling pigs. Jounnal of Animal Science, Champaign, 63(6): $1845-53,1986$.

CUMBY, T.R. Design requirements of liquid feeding systems for plgs: a review. Journal of Agricultural Engineering Research, New York, 34: 153-72, 1986.

DECUYPERE,J.A.; BOSSUYT,R.; HENDERICKX, H.K. Gastric secretion in suckling pigs and early-weaned pigs given a dry cow's-milk formula ad lib. British Journal of Nutrition, London, 40: 91-102, 1978.

DECUYPERE,J.A.; MEEUSEN, A.; HENDERICKX, H.K. Influence of the partial replacement of milk protein by soybean protein isolates with different physical properties on the performance and nitrogen digestibility of early-weaned pigs. Iournal of Animal Science, Champaign, 53(4): 1011-8, 1981.

EFIRD, R.C.; ARMSTRONG, W.D.; HERMAN, D.L. The development of digestive capacity in youns pios: effects of age and weaning system. Journal of Animal Science, Champaion, 
55(6): 1380-7, Jun. 1982.

FERREIRA, A.S. Estimativa de produção e composição do leite de porca e aleitamento artificial de leitões. Viçosa, 1986. 121p. CDoutorado - Universidade Federal de Viçosa).

FERREIRA, A.S.; COSTA, P.M.A.; GOMES, J.G.; GALVAO, J.G. Aleitamento artificial de leitơes usando extrato preparado com proteína isolada de soja pré-cozida, com ou sem antibiótico. Revista da Sociedade Brasileira de Zootecnia, Viçosa, $\underline{17}(3):$ 221-6, $1988 a$.

FERREIRA, A.S.; COSTA, P.M.A.; GOMES, J.G.; ROSTAGNO, H.S. Aleitamento natural vs. aleitamento artificial de leitões com a utilização de leite de porca e de vaca ou extrato de soja. Revista da Sociedade Brasileira de Zootecnia, Viçosa, 17(3): 227-37, $1988 b$.

GADD, J. Avoid post weaning check. Pigs, Doetinchem, $\underline{2}(1)$ : 34-7, Jan. 1986.

GRANT, A.L.; THOMAS,J.W.; EMERY, R.S.; KING, K.J.; LIESMAN, J.S. Small intestinal parameters in piglets fied an all milk protein milk replacer or a special soy protein concentrate replacer supplemented with amines. In: 
ANNUAL MEETING OF THE AMERICAN SOCIETY OF ANIMAL SGIENGE, 79., Nashville, 1987. Abst.racts Journal of Animal Science, Champaign, 65(supl.1): 293, 1987.

HARTMAN, P.A.; HAYS, V.W.; BAKER, R.O.; NEAGLE, L.H.; GATRON, D.V. Digestive enzyme developments in the young pig. Journal of Animal Science, Champaign, 20: 114-23, 1961.

HAYE, S.N. \& KORNEGAY, E.T. Immunoglobulin $G, A$ and $M$ and antibody response in sow-reared and artificially-reared

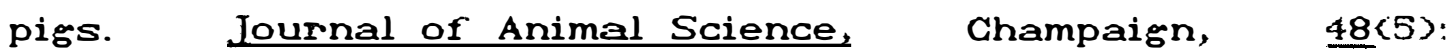
$1116-22,1979$.

JONES, E.E.; COALSON, J.A.; LECGE, J.G. Soy t'lour as a source of protein for baby pigs. Iournal of Animal Science, Champaign, 45(5): 1073-8, May. 1977.

JUNQUEIRA, O.M. \& ARAUJO, W.A. Alguns aspectos nutricionais dos suinos após a desmama. Suinoculturá Industrial, São Paulo, 87: 32-6, 1986.

KELLEY, K. \& EASTER, R. Nutritional factors can influence immune response of swine. Feedstuffs, Minnentonka, 59(22): 14-7, 1987. 
KNUDSON, B.K.; HEDGES, J.D.; RADVANSKY, M.L.; LONG, J.I. Milk replacer supplemented to lactated lit.ters. In: ANNUAL MEETING OF THE AMERICAN SOCIETY OF ANIMAL SCIENGE, 79., Nashville, 1987. Abstracts Journal of Animal Science, Champaion, 65(supl.1): 293, 1987.

LANDELL, L.G.F.; COSTA, P.M.A.; GOELHO, D.T.; MELLO, H.V.; PEREIRA, J.A.A.; ROSTAGNO, H.S. Substituiçăo do leite de vaca pelo leite de soja, na alimentação de leit.ớes desmamados aos 14 dias de idade. Revista da Sociedade Brasileira de Zootecnia, Viçosa, 14(1): $130-40,1985 a$.

LANDELL, L.G.F.; COSTA, P.M.A.; COELHO, D.T.; PEREIRA, J.A.A.; ROSTAGNo, H.S.; MELlo, H.V. Utilização do leite de soja na alimentação de leitões desmamados aos 14 dias de idade. Revista da Sociedade Brasileira de Zootecnia, Viçosa, 14(1): 106-18, 1985と.

LEGGE, J.G. Rearing neonatal piglets of low birth weight with an automatic feeding device. Journal of Animal Science, Champaign, 33(1): 47-51, 1971.

LEGGE, J.G. Rearing piglets in a farm enviroment: a promise unfulfilled. Journal of Animal Science, Champaign, 41(2): 659-66, 1975. 
LEGGE, J.G. \& GOALSON, J.A. Diets for rearing colostrum-free piglets with an automatic feeding device. Iournal of Animal Science, Champaign, 42(3): 622-9, 1976.

LECGE, J.G.; ARMSTRONG, W.D.; GRAWFORD, F.C.; DUCHARME, G.A. Nutrition and management of early weaned piglets: liquid vs dry feeding. Journal of Animal Science, Champaign, 48(5): 1007-14, 1979.

LEIBRANDT, V. \& KEMPT, R.A. Effect of feeding liquid milk replacer after weaning evaluated. Feedstuffs, Minnentonka, $\underline{59}(45): 14-5,1987$.

LEWIS, A.J.; SPEER, V.G.; HAUGHT, D.G. Relationship between yield and composition of sows' milk and weight gains of nursing pigs. Journal of Animal Science, Champaign, 47(3): 634-8, Mar. 1978.

McEVAN, A.D.; FISHER, E.W.; SELMAN, I.E.; PENHALE, W.J. A turbidity test. for the estimation of immune globulin levels in neonatal calf serum. Clinica Chimica Acta, Amsterdam, 27: 155-63, 1970.

MANNERS, M.J. Milk replacers for piglets. Journal of the 
Science of Food and Asriculture, London, 로 $333-40$, 1970.

MATEO, J.F. \& VEUM, T.L. Utilization of casein or isolated soybean protein supplemented with amino acids and glucose or lactose by neonatal piglets reared artificially. Journal of Animal Science, Champaign, 50(5): 869-70, May. 1980.

MENGE, H. \& FROBISH, L.T. Nutritional studies with the early weaned neonatal pig. Iournal of Animal Science, Champaign, 42(1): 99-105, 1976.

MILLER, B.G.; JAMES, P.S.; SMITH, M.W.; BOURNE, F.J. Effect of weaning on the capacity of pig intestinal villi to digest and absorb nutrients. Iournal of Agricultural Science, Cambridge, 107(3): 579-89, 1986.

MILLER, E.R.; HARMON, B.G.; ULLREY, D.E.; SCHMIDT, D.A.; LUECKE, R.W.; HOEFER, J.A. Antibody absorption, retention and production by the baby pig. Journal of Animal Sicience, Champaign, 21(2): 309-14, 1962.

NEWPORT, M.J. El destete temprano de los cerdos. Revista Mundial de Zootecnia, Roma, 24: 34-9, 1977. 
100.

PETTIGREW, J.E. \& HARMON, B.G. Milk proteirs for artificially reared piglets. I. Comparison to egg white protein and effect of added immunoglobulins. Iournal of Animal Science, Champaign, 44(3): 374-82, 1977.

PETTIGREW, J.E.; HARMON, B.G.; SIMON, J.; BAKEK, O.H. Milk proteins for artificially reared piglets. II. Comparison to a skim milk hydrolisate. Journal of Animal Science, Champaign, 44(3): 383-8, 1977 a.

PETTIGREW, J.E.; HARMON, B.G.; GURTIS, S.E.; CORNELIUS, S.G.; NORTON, H.W.; JENSEN, A.H. Milk proteins for artificially reared piglets. III. Efficacy of sodium caseinate and sweet dried whey. Journal of Animal Science, Champaign, 45(2): 261-8, 1977 b.

PFEIfFER, N.E.; MCGUIRE, T.C.; BENDEL, R.B.; WEIKEL, J.M. Quantification of bovine immunoglobulins: comparison of single radial immunodiffusion, zinc sulfate turbidity, serum eletrophoresis and rerractometer methods. Americar Iournal of Veterinary Research, Ghicago, 38(5): 693-8, 1977.

POND, W.G.; SNYDER, W.; WALKER, E.F.Jr.; STILLING, B.R. Comparative utilization of casein, fish protein 
concentrate and isolated soybean protein in liquid diets for growth of baby pigs. Journal of Animal Science, Champaign, $33(3): 587-91,1971$.

RATCLIFFE, B.; SMITH, M.W.; MILLER, B.G.; JAMES, F.S.; BOURNE, F.J. Effect, of soyabean protein on the ability of gnotobiotic pig intestine to digest and absorb nutrients. Journal of Asricultural Science, Cambridge, 112: $123-30,1989$.

REINHOLD, J.G. Total protein albumin, and globulin. In: STANDARD METHODS OF CLINIGAL CHEMISTRY, 1.,New York, Academic Press, 1953. p.88.

RODRIGUEZ, J.P. \& YOUNG, L.G. Utilization of corn and wheat in diet,s of pigs weaned at 7 days of age. Journal Animal Science, Champaign, 53(3): 683-92, Mar. 1981.

SCHNEIDER, D.L. \& SARETT, H.D. Growth of baby pigs fed infant soybean formulas. Iournal of Nutrition, Bethesda, 98(3): 279-87, 1969.

SHERRY, M.P.; SCHMIDT, M.K.; VEUM, T.L. Dietary protein to calorie ratios and fat sources for neonatal piglets reared artificially with subsequent performance. I. Performance. Journal of Animal Science, Champaign, 
46(5): $1259-60,1978 a$.

SHERRY, M.P.; SCHMIDT, M.K.; VEUM, T.L. Ferformance of neonatal piglets mechanically fed diets containing corn, soybean meal and milk protein. Journal of Animal Science, Champaisn, 46(5): 1250-8, $1978 \mathrm{~b}$.

SHERRY, M.P.; VEUM, T.L.; SCHMIDT, M.K.; HUTCHESON, D.P. Dietary protein to calorie ratios and fat sources for neonatal piglets reared artificially with subsequent performance. II. Serum variables Iournal of Animal Science, Champaign, 46(5): 1267-74, $1978 c$.

TARDIN, A.C. Fisiologia digestiva e nutrição no desmame precoce de leitठ̋es. In: CONGRESSO LATINO DE VETERINARIOS ESPECIALISTAS EM SUINOS, 1., Rio de Janeiro, 1985. Anais. Rio de Janeiro, Associação Brasileira de Veterinários Especialistas em Suinos, 1985. p.33-57.

VARGAS, J. Dietas liquidas de destete: $19 \%$ más en peso. Industria Porcina, Mount Morris, 25-7, 1987.

VARLEY, M.A.; FOWLER, V.R.; MAITLAND, for colostrum-deprived neonatal piglets. Laboratory Animals, London, 19: 290-0, 1985. 
WILSON, M.R. Immunologic development of the neonatal pig Journal of Animal Science, Champaign, $\underline{38(5)}$ 1018-21, 1974.

ZAMORA, R.G. \& VEUM, T.L. Various levels of soybean meal as replacement for dried skim milk for artificially reared neonatal pigs. Nutrition Reports International, Los Altos, 18(5): 495-502, 1978.

ZAMORA, R.G. \& VEUM, T.L. The effects of increasing the levels of soybean protein in the diets for artificially reared neonatal pios. Nutrition Reports International, Los Alt.os, 19(1): 49-56, 1979.

ZONTA, E.P. \& MACHADO, A.A. SANEST - Sistema de análise estatistica, 1983. 
104

A P E N D I G E 
105.

Apêndice 01 - Análises quimicas aproximadas de amostras de raçőes fase pre-inicial realizadas durante o periodo experimental.

\begin{tabular}{|c|c|c|c|c|c|c|c|c|c|}
\hline & \multicolumn{2}{|c|}{$14,4 \%$} & leite & \multicolumn{2}{|c|}{$9,6 \%$} & leite & \multicolumn{3}{|c|}{ controle } \\
\hline & esp. & far. & pel & esp. & far. & pel. & esp. & far. & pel. \\
\hline \multicolumn{10}{|c|}{ Granul ometria } \\
\hline 1. & 2,50 & 1,10 & - & 2,50 & 1,50 & - & - & - & - \\
\hline 2. & 30,00 & 30,00 & - & 30,00 & 31,00 & - & - & - & - \\
\hline 3. & 25,00 & 10,10 & - & 25,00 & 12,20 & - & - & - & - \\
\hline 4. & 30,00 & 40,80 & - & 30,00 & 34,90 & - & - & - & - \\
\hline 5. & 12,50 & 18,00 & - & 12,50 & 20,40 & - & - & - & - \\
\hline \multicolumn{7}{|c|}{ Análises Bromatológicas } & $\% b$ & & \\
\hline 1. & 12,00 & 9,63 & 8,80 & 12,00 & 10,60 & 9,46 & 12,00 & 6,19 & 9,31 \\
\hline 2. & 20,54 & 20,53 & 20,87 & 20,90 & 20,72 & 21,41 & 21,48 & 21,72 & 21,17 \\
\hline 3. & 3,99 & 2,78 & 3,45 & 3,74 & 2,42 & 3,13 & 3,23 & 2,27 & 2,56 \\
\hline 4. & 3,63 & 3,42 & 4,87 & 3,82 & 4,01 & 3,57 & 4,29 & 4,43 & 4,52 \\
\hline 5. & 5,18 & 5,40 & 5,41 & 5,12 & 5,06 & 5,50 & 5,10 & 5,79 & 5,10 \\
\hline 6. & 0,91 & 0,98 & 0,96 & 0,90 & 1,00 & 0,98 & 0,92 & 1,04 & 0,88 \\
\hline 7. & 0,04 & 0,58 & 0,64 & 0,04 & 0,04 & 0,04 & 0,05 & 0,73 & 0,64 \\
\hline
\end{tabular}

a. oranulometria: 1. retido na peneira 10 mesh, 2 . retido na peneira 20 mesh, 3 . retido na peneira 90 mash, 4. retido na peneira 50 mesh e 5 . passados na peneira 50 mesh

b. Analises Bromatologicas: 1. Umidade, 2. Proteina bruta, 3. Extrato etéreo, 4. Fibra bruta, 5. Matéria mineral, $\sigma$. Cálcio e ?. Fósforo 
Apéndice 02 - Analises quimicas aproximadas de amostras de raçōes fase inicial realizadas durante o periodo experimental.

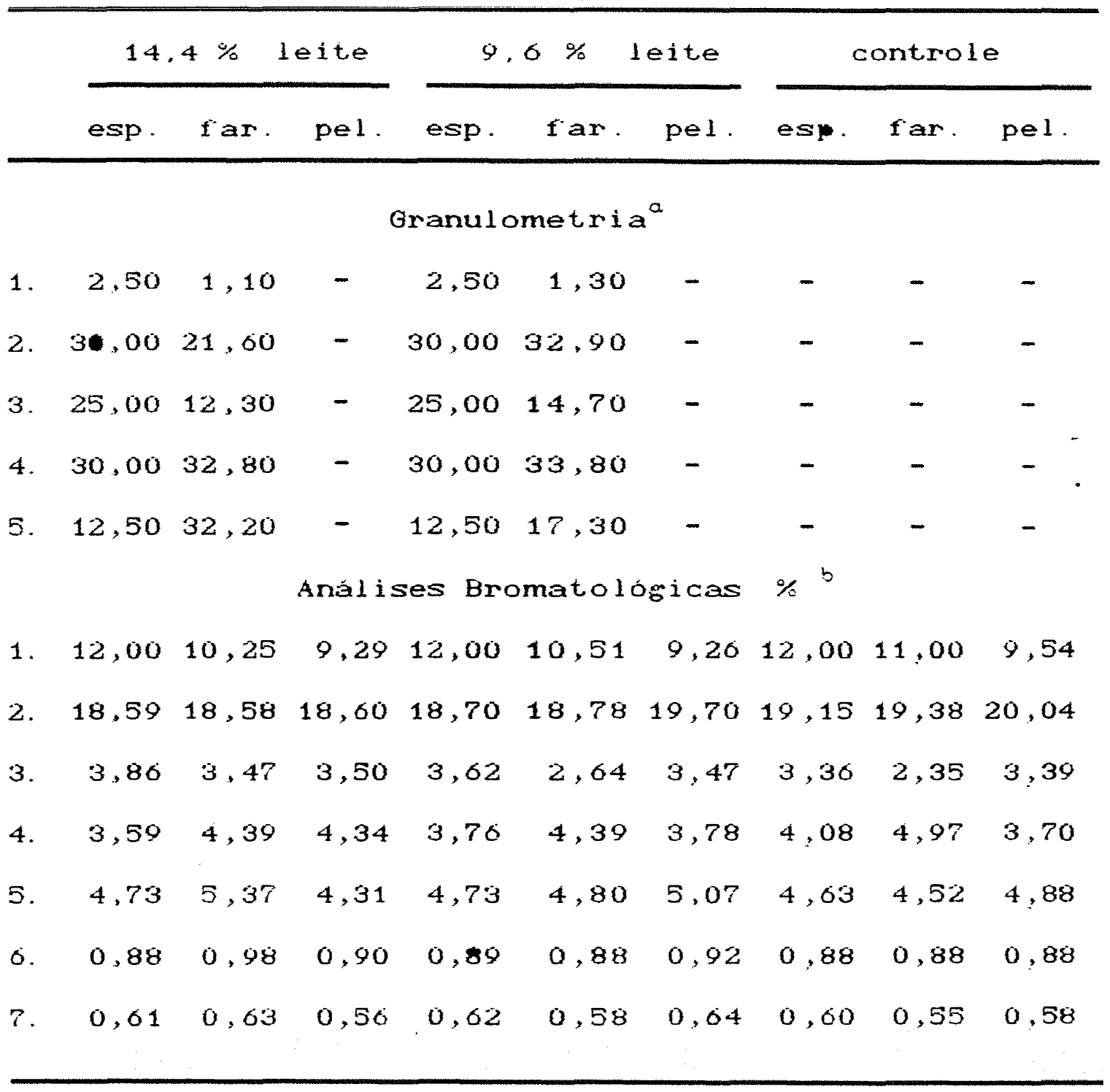

a.aranulometria: 1. retido na peneira 10 mesh, 2. retido na peneira 20 mesh, 3. retido na peneira 30 mesh, 4. retido na peneira 50 mest e 5 . passados ra peneira $5 \mathrm{C}$ mesh.

b. Análises Bromatológicas: 1. Umidade, 2 . Proteinabruta, 3. Extrato etéreo, 4. Fibrabruta, 5. Matéria mineral, o. cálaio e T. Fósforo. 
107.

Apéndice 03 - Numero de leitões utilizados no experimento.

\begin{tabular}{|c|c|c|c|c|c|c|c|c|c|c|}
\hline \multirow[b]{2}{*}{$\operatorname{Tr}$} & \multirow[b]{2}{*}{ Bloco } & \multicolumn{9}{|c|}{ Idade ( dias ? } \\
\hline & & 0 & 7 & 14 & 21 & 28 & 35 & 42 & 49 & 61 \\
\hline \multirow[t]{5}{*}{1} & 1 & 10 & 10 & 10 & 10 & 10 & 10 & 10 & 10 & 10 \\
\hline & 2 & 10 & 10 & 10 & 10 & 10 & 10 & 10 & 10 & 10 \\
\hline & 3 & 10 & $1 \bullet$ & $\varphi$ & 9 & 9 & 9 & 9 & 8 & 8 \\
\hline & 4 & 11 & 11 & 11 & 11 & 11 & 1 & 10 & 10 & 10 \\
\hline & Total & 41 & 41 & 40 & 40 & 40 & 40 & 39 & 38 & 38 \\
\hline \multirow[t]{5}{*}{2} & 1 & 10 & 10 & 8 & 8 & 8 & 8 & 7 & 7 & 7 \\
\hline & 2 & 11 & 11 & 11 & 11 & 11 & 11 & 11 & 11 & 11 \\
\hline & 3 & 10 & 10 & 10 & 10 & 10 & 10 & 10 & 10 & 10 \\
\hline & 4 & 10 & 10 & 10 & 10 & 10 & 10 & 10 & 10 & 10 \\
\hline & Total & 41 & 41 & 39 & 30 & 39 & 39 & 38 & 38 & 38 \\
\hline \multirow[t]{5}{*}{3} & 1 & 10 & 10 & 10 & 10 & 10 & 10 & 10 & 10 & 10 \\
\hline & 2 & 8 & 8 & 8 & 8 & 8 & 8 & 8 & 8 & 8 \\
\hline & 3 & 11 & 11 & 11 & 11 & 11 & 11 & 11 & 11 & 11 \\
\hline & 4 & 11 & 11 & 11 & 11 & 11 & 11 & 11 & 11 & 11 \\
\hline & Total & 40 & 40 & 40 & 40 & 40 & 40 & 40 & 40 & 40 \\
\hline \multirow[t]{5}{*}{4} & 1 & 9 & 9 & $\dot{\varphi}$ & 9 & 9 & 9 & 9 & 9 & 9 \\
\hline & 2 & 10 & 10 & 10 & 10 & 10 & 10 & 10 & 10 & 10 \\
\hline & 3 & 12 & 12 & 12 & 12 & 12 & 12 & 11 & 11 & 11 \\
\hline & 4 & 10 & 10 & 10 & 10 & 10 & 10 & 10 & 10 & 10 \\
\hline & Total & 41 & 41 & 41 & 41 & 41 & 41 & 40 & 40 & 40 \\
\hline \multirow[t]{5}{*}{5} & 1 & 10 & 10 & 10 & 10 & 10 & 10 & 10 & 10 & 10 \\
\hline & 2 & 11 & 11 & 11 & 11 & 11 & 11 & 8 & 8 & 8 \\
\hline & 3 & 10 & 10 & 10 & 10 & 10 & 10 & 10 & 10 & 10 \\
\hline & 4 & 9 & 9 & 9 & 9 & 8 & 8 & 7 & 7 & $?$ \\
\hline & Total & 40 & 40 & 40 & 40 & 39 & 39 & 35 & 35 & 35 \\
\hline \multirow[t]{5}{*}{6} & 1 & 10 & 10 & 9 & 9 & 9 & 9 & $\varphi$ & $\dot{y}$ & 9 \\
\hline & 2 & 10 & 10 & 10 & 10 & 10 & 10 & 10 & 10 & 10 \\
\hline & 3 & 12 & 12 & 12 & 12 & 12 & 12 & 12 & 12 & 12 \\
\hline & 4 & 10 & 10 & 10 & 10 & 10 & 10 & 10 & 10 & 10 \\
\hline & Tota 1 & 42 & 42 & 41 & 41 & 41 & 41 & 41 & 41 & 41 \\
\hline \multirow[t]{5}{*}{7} & 1 & 10 & 10 & 10 & 10 & 10 & 10 & 10 & 10 & 10 \\
\hline & 2 & 10 & 10 & 10 & 10 & 10 & 10 & 10 & 10 & 10 \\
\hline & 3 & 9 & 9 & 9 & 9 & 9 & 9 & 9 & 9 & 9 \\
\hline & 4 & 10 & 10 & 10 & 10 & 10 & 10 & 10 & 10 & 10 \\
\hline & Total & 39 & 39 & 39 & 39 & 39 & 39 & 39 & 39 & 39 \\
\hline \multirow[t]{5}{*}{8} & 1 & 9 & 9 & $\varphi$ & $\varphi$ & 9 & 9 & 9 & 9 & 9 \\
\hline & $\ddot{2}$ & 9 & 9 & 9 & $\varphi$ & 9 & 9 & 9 & 9 & 9 \\
\hline & 3 & 7 & 7 & 7 & 7 & 7 & 7 & 7 & 7 & 7 \\
\hline & 4 & 10 & 10 & 10 & 10 & 10 & 10 & 10 & 10 & 10 \\
\hline & Total & 35 & 35 & 35 & 35 & 35 & 35 & 35 & 35 & 35 \\
\hline
\end{tabular}


Apéndice 04 - Peso médio dos animais, em $\mathrm{kg}$.

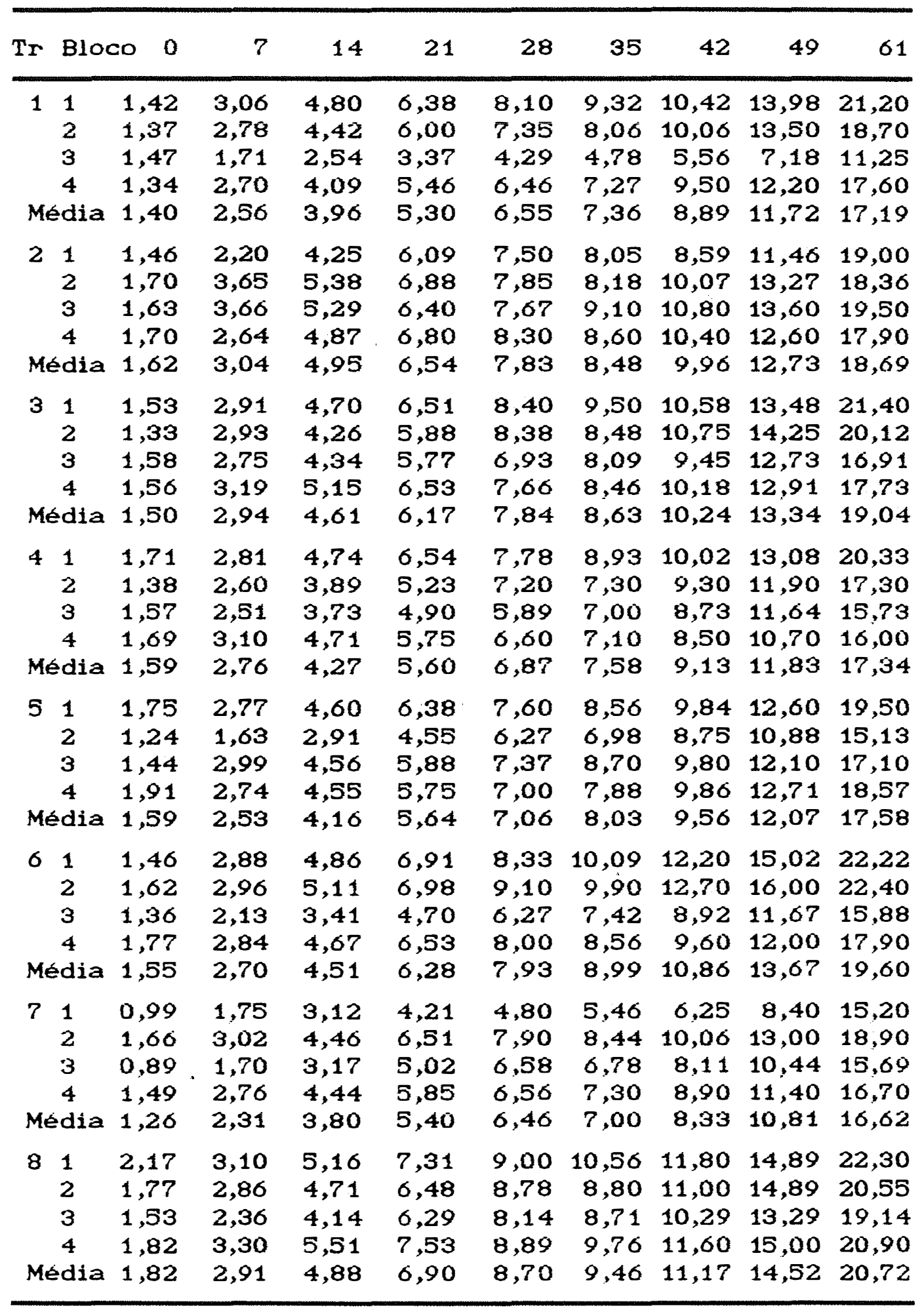


Apèndice 05 - Consumo médio de ração dos animais, a partir de 21 dias, em ko.

\begin{tabular}{|c|c|c|c|c|c|c|c|}
\hline $\operatorname{Tr}$ & Bloco & 28 & 35 & 42 & 49 & 61 & \\
\hline 1 & 1 & 0,195 & 1,795 & 4,535 & 9,135 & 21,835 & \\
\hline 1 & 2 & 0,020 & 1,040 & 3,840 & 8,620 & 18,540 & \\
\hline 1 & 3 & 0,011 & 0,922 & 2,333 & 10,146 & 22,646 & \\
\hline \multirow[t]{2}{*}{1} & 4 & 0,036 & 1,263 & 4,393 & 8,373 & 20,373 & \\
\hline & Média & 0,111 & 1,255 & 3,775 & 9,069 & 20,849 & \\
\hline 2 & 1 & 0,038 & 0,962 & 3,106 & 7,734 & 22,734 & \\
\hline 2 & 2 & 0,000 & 0,818 & 3,218 & 7,800 & 16,818 & \\
\hline 2 & 3 & 0,040 & 1,760 & 4,330 & 8,980 & 19,180 & \\
\hline \multirow[t]{2}{*}{2} & 4 & 0,000 & 1,010 & 3,880 & 7,200 & 17,260 & \\
\hline & Media & 0,020 & 1,138 & 3,634 & 7,944 & 18,998 & \\
\hline 3 & 1 & 0,140 & 1,440 & 3,780 & 7,020 & 20,220 & \\
\hline 3 & 2 & 0,112 & 1,338 & 4,350 & 9,212 & 21,138 & \\
\hline 3 & 3 & 0,055 & 1,437 & 3,592 & 7,510 & 16,783 & \\
\hline \multirow[t]{2}{*}{3} & 4 & 0,000 & 1,045 & 3,854 & 8,327 & 18,418 & \\
\hline & Média & 0,077 & 1,315 & 3,894 & 8,167 & 19,140 & \\
\hline 4 & 1 & 0,011 & 1,101 & 3,411 & 7,541 & 18,981 & \\
\hline 4 & 2 & 0,000 & 1,060 & 3,390 & 7,120 & 17,460 & \\
\hline 4 & 3 & $0,00 *$ & 1,025 & 3,270 & 7,079 & 16,352 & \\
\hline \multirow[t]{2}{*}{4} & 4 & 0,030 & 1,210 & 3,040 & 6,080 & 15,380 & \\
\hline & Média & 0,012 & 1,099 & 3,278 & 6,955 & 17,043 & \\
\hline 5 & 1 & 0,060 & 0,880 & 2,540 & 5,840 & 18,340 & \\
\hline 5 & 2 & 0,045 & 0,718 & 1,918 & 4,568 & 16,268 & \\
\hline 5 & 3 & 0,010 & 0,830 & 2,240 & 8,910 & 18,910 & \\
\hline \multirow[t]{2}{*}{5} & 4 & 0,025 & 0,638 & 3,109 & 9,423 & 21,852 & \\
\hline & Media & 0,035 & 0,767 & 2,452 & 7,185 & 18,843 & \\
\hline 6 & 1 & 0,044 & 1,200 & 4,000 & 7,710 & 20,599 & \\
\hline 0 & 2 & 0,000 & 0,900 & 3,090 & 6,800 & 17,700 & \\
\hline 6 & 3 & 0,050 & 0,983 & 2,208 & 4,750 & 13,083 & \\
\hline \multirow[t]{2}{*}{6} & 4 & 0,120 & 0,810 & 2,580 & 4,000 & 14,800 & \\
\hline & Media & 0,054 & 0,973 & 2,970 & 5,815 & 16,546 & \\
\hline 7 & 1 & 0,020 & 0,680 & 2,420 & 5,520 & 10,020 & \\
\hline 7 & 2 & 0,000 & 0,940 & 3,520 & 7,680 & 17,680 & \\
\hline 7 & 3 & 0,000 & 0,800 & 2,544 & 8,711 & 19,822 & \\
\hline \multirow[t]{2}{*}{7} & 4 & 0,050 & 1,000 & 3,570 & 0,490 & 16,490 & \\
\hline & Média & 0,018 & 0,855 & 3,014 & 7,100 & 17,503 & \\
\hline 8 & 1 & 0,078 & 1,678 & 3,922 & 8,078 & 20,856 & \\
\hline 8 & 2 & 0,033 & 0,960 & 3,999 & 9,277 & 21,210 & \\
\hline 8 & 3 & 0,086 & 1,543 & 3,786 & 8,429 & 22,715 & 7 \\
\hline \multirow[t]{2}{*}{8} & 4 & 0,040 & 1,410 & 4,360 & 9,000 & 20,560 & \\
\hline & Média & 0,059 & 1,399 & 4,017 & 8,711 & 21,335 & \\
\hline
\end{tabular}


Apêndice 06 - Consumo de dieta liquida, dos 21 aos 49 dias, em litros.

\begin{tabular}{|c|c|c|c|c|c|c|}
\hline $\mathrm{Tr}$ & Bloco & 28 & 35 & 42 & 49 & \\
\hline \multirow[t]{5}{*}{5} & 1 & 2,250 & 6,090 & 14,78 & 23,280 & \\
\hline & 2 & 1,970 & 7,880 & 25,38 & 37,760 & \\
\hline & 3 & 1,490 & 8,390 & 23,39 & 43,390 & \\
\hline & 4 & 1,875 & 15,630 & 34,20 & 52,770 & \\
\hline & dia & 1,896 & 9,498 & 24,43 & 39,300 & \\
\hline \multirow[t]{5}{*}{6} & 1 & 1,570 & 5,900 & 18,29 & 27,750 & \\
\hline & 2 & 1,470 & 11,620 & 28,62 & 50,620 & \\
\hline & 3 & 2,420 & 7,750 & 21,92 & 38,580 & \\
\hline & 4 & 0,870 & 10,070 & 21,42 & 33,670 & - \\
\hline & dia & 1,583 & 8,835 & 22,56 & 37,655 & - \\
\hline
\end{tabular}


Apèndice of - Ganhos diários de peso (GDP, kg), dos animais nas fases pre-inicial, inicial e total.

\begin{tabular}{|c|c|c|c|c|}
\hline $\operatorname{Tr}$ & Bloco & Pré-Ini & Inicial & Total \\
\hline \multirow[t]{5}{*}{1} & 1 & 0,271 & 0,002 & 0,371 \\
\hline & 2 & 0,268 & 0,433 & 0,318 \\
\hline & 3 & 0,136 & 0,339 & 0,197 \\
\hline & 4 & 0,241 & 0,450 & 0,304 \\
\hline & Media & 0,229 & 0,456 & 0,298 \\
\hline \multirow[t]{5}{*}{2} & 1 & 0,192 & 0,628 & 0,323 \\
\hline & 2 & 0,228 & 0,424 & 0,287 \\
\hline & 3 & 0,257 & 0,492 & 0,328 \\
\hline & 4 & 0.207 & 0,442 & 0,278 \\
\hline & Media & 0,221 & 0,497 & 0,304 \\
\hline \multirow[t]{5}{*}{3} & 1 & 0,249 & 0,660 & 0,372 \\
\hline & 2 & 0,299 & 0,489 & 0,356 \\
\hline & 3 & 0,249 & 0,348 & 0,279 \\
\hline & 4 & 0,228 & 0,402 & 0,280 \\
\hline & Media & 0,256 & 0,475 & 0,322 \\
\hline \multirow[t]{5}{*}{4} & 1 & 0,234 & 0,604 & 0,345 \\
\hline & 2 & 0,238 & 0,450 & 0,302 \\
\hline & 3 & 0,241 & 0,341 & 0,271 \\
\hline & 4 & 0,177 & 0,442 & 0,256 \\
\hline & Media & 0,223 & 0,459 & 0,294 \\
\hline \multirow[t]{5}{*}{5} & 1 & 0,222 & 0,575 & 0,328 \\
\hline & 2 & 0,226 & 0,354 & 0,264 \\
\hline & 3 & 0,222 & 0,417 & 0,280 \\
\hline & 4 & 0,249 & 0,488 & 0,320 \\
\hline & Media & 0,230 & 0,459 & 0,298 \\
\hline \multirow[t]{5}{*}{6} & 1 & 0,290 & 0,600 & 0,383 \\
\hline & 2 & 0,322 & 0,533 & 0,380 \\
\hline & 3 & 0,249 & 0,351 & 0,280 \\
\hline & 4 & 0,195 & 0,492 & 0,284 \\
\hline & Média & 0,264 & 0,494 & 0,333 \\
\hline \multirow[t]{5}{*}{7} & 1 & 0,150 & 0,567 & 0,275 \\
\hline & 2 & 0,232 & 0,492 & 0,310 \\
\hline & 3 & 0,194 & 0,438 & 0,267 \\
\hline & 4 & 0,198 & 0,442 & 0,271 \\
\hline & Média & 0,193 & 0,485 & 0,281 \\
\hline \multirow[t]{5}{*}{8} & 1 & 0,271 & 0,618 & 0,375 \\
\hline & 2 & 0,300 & 0,472 & 0,352 \\
\hline & 3 & 0,250 & 0,488 & 0,321 \\
\hline & 4 & 0,267 & 0,492 & 0,334 \\
\hline & Média & 0,272 & 0,518 & 0,346 \\
\hline
\end{tabular}


112.

\begin{tabular}{|c|c|c|c|c|c|c|}
\hline Apêl & dice 08 & \multirow{2}{*}{$\begin{array}{l}\begin{array}{l}\text { Consumo } \\
\text { animais } \\
\text { total. }\end{array} \\
\text { Pre- }\end{array}$} & \multirow{2}{*}{$\begin{array}{l}\text { diário } \\
\text { nas }\end{array}$} & \multirow{2}{*}{$\frac{\begin{array}{c}\text { de } \\
\text { fases }\end{array}}{\text { Inicia }}$} & $\begin{array}{c}\text { ração, CCDR, } \\
\text { pre-inicial, }\end{array}$ & \multirow[t]{2}{*}{$\begin{array}{l}\text { kg), } \\
\text { inicia }\end{array}$} \\
\hline \multirow[b]{2}{*}{$\operatorname{Tr}$} & \multirow[b]{2}{*}{ Bloco } & & & & Total & \\
\hline & & \multicolumn{2}{|l|}{$a$} & tister & $a$ & b \\
\hline \multirow[t]{4}{*}{1} & 1 & 0,320 & & 1,058 & 0.546 & \\
\hline & 2 & 0,308 & & 0,827 & 0,463 & \\
\hline & 3 & 0,362 & & 1,042 & 0,506 & \\
\hline & 4 & 0,299 & & 1,698 & 0,509 & \\
\hline \multicolumn{2}{|c|}{ Média } & 0,324 & & 1,156 & 0,521 & \\
\hline \multirow[t]{4}{*}{2} & 1 & 0,276 & & 1,250 & 0,568 & \\
\hline & 2 & 0,279 & & 0,752 & 0,420 & \\
\hline & 3 & 0,321 & & 0,850 & 0,480 & \\
\hline & 4 & 0,259 & & 0,833 & 0,432 & \\
\hline \multicolumn{2}{|c|}{ Media } & 0,284 & & 0,921 & 0.475 & \\
\hline \multirow[t]{4}{*}{3} & 1 & 0,272 & & 1,050 & 0,506 & \\
\hline & 2 & 0,329 & & 0,994 & 0,528 & \\
\hline & 3 & 0,268 & & 0,773 & 0,420 & \\
\hline & 4 & 0,297 & & 0,841 & 0,460 & \\
\hline \multicolumn{2}{|c|}{ Media } & 0,292 & & 0,915 & 0,479 & \\
\hline \multirow[t]{4}{*}{4} & 1 & 0.269 & & $0,95: 3$ & 0,475 & \\
\hline & 2 & 0,254 & & 0,862 & 0,437 & \\
\hline & 3 & 0,253 & & 0,773 & 0,409 & \\
\hline & 4 & 0,217 & & 0,775 & 0,385 & \\
\hline \multicolumn{2}{|c|}{ Média } & 0,248 & & 0,841 & 0,427 & \\
\hline \multirow[t]{4}{*}{5} & 1 & 0,209 & 0,292 & 1,042 & 0,459 & 0,517 \\
\hline & $\ddot{z}$ & 0,163 & 0,298 & 0,975 & 0,407 & 0,501 \\
\hline & 3 & 0,318 & 0,473 & 0,833 & 0,473 & 0,581 \\
\hline & 4 & 0,337 & 0,525 & 1,036 & 0,540 & 0,678 \\
\hline \multicolumn{2}{|c|}{ Media } & 0,257 & 0,397 & 0,972 & 0,471 & 0,569 \\
\hline \multirow[t]{4}{*}{6} & 1 & 0.275 & 0,374 & 1,074 & 0,515 & 0.584 \\
\hline & 2 & 0,243 & 0,424 & 0,908 & 0,442 & 0,569 \\
\hline & 3 & 0,170 & 0,307 & 0,694 & 0,327 & 0,424 \\
\hline & 4 & 0,143 & 0,263 & 0,900 & 0,370 & 0,454 \\
\hline \multicolumn{2}{|c|}{ Media } & 0,208 & 0,342 & 0,894 & 0,414 & 0,508 \\
\hline \multirow[t]{4}{*}{7} & 1 & 0,197 & & 0,875 & 0,400 & \\
\hline & 2 & 0,274 & & 0,833 & 0,442 & \\
\hline & 3 & 0,311 & & 0,926 & 0,490 & \\
\hline & 4 & 0,232 & & 0,833 & 0.412 & \\
\hline & dia & 0,254 & & 0,867 & 0,438 & \\
\hline 8 & 1 & 0,289 & & 1,065 & 0,521 & \\
\hline & 2 & 0,331 & & 0,994 & 0,530 & \\
\hline & 3 & 0,301 & & 1,191 & 0,508 & \\
\hline & 4 & 0,324 & & $0, \grave{958}$ & 0,514 & \\
\hline & dia & 0,311 & & 1,052 & 0,533 & \\
\hline
\end{tabular}

a. CDR calculado apen as $c o m$ os $d a d o s$ de ração sól ida

b. CDR calculado com os da dos de racão sólid a somado ao consumo da dieta $l i$ quid a 
113.

Apéndice 09 - Conversão alimentar (CA), dos animais nas fases pré-inicial, inicial e total.

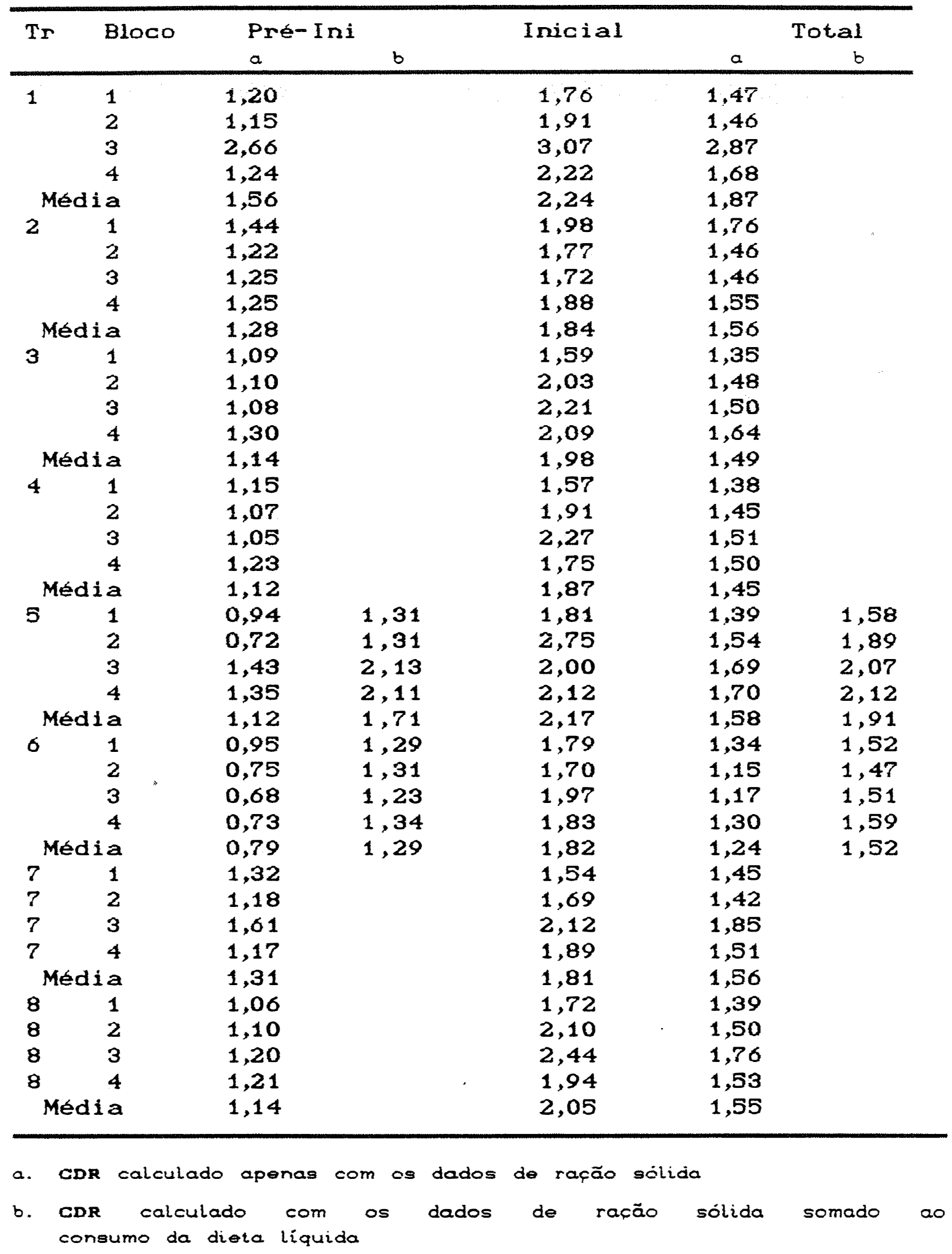


Apendice 10 - Temperaturas minimas e máximas resistradas durante o periodo experimental, ${ }^{\circ} \mathrm{C}$.

\begin{tabular}{|c|c|c|c|c|c|c|c|c|}
\hline \multirow[b]{2}{*}{ Data } & \multirow[b]{2}{*}{$a$} & \multirow[b]{2}{*}{$b$} & \multicolumn{3}{|c|}{ Maternidade } & \multirow[b]{2}{*}{ Data } & \multirow[b]{2}{*}{ a } & \multirow[b]{2}{*}{$b$} \\
\hline & & & Data & a & $b$ & & & \\
\hline $01 / 10 / 88$ & 20 & 26 & $01 / 11 / 88$ & 23 & 27 & $01 / 12 / 88$ & 26 & 27 \\
\hline $02 / 10 / 88$ & 21 & 27 & $02 / 11 / 88$ & 19 & 24 & $02 / 12 / 88$ & 23 & 29 \\
\hline $03 / 10 / 88$ & 20 & 30 & $03 / 11 / 88$ & 18 & 22 & $03 / 12 / 88$ & 21 & 24 \\
\hline $04 / 10 / 88$ & 24 & 30 & $04 / 11 / 88$ & 19 & 23 & $04 / 12 / 88$ & 20 & 29 \\
\hline $05 / 10 / 88$ & 18 & 27 & $05 / 11 / 88$ & 18 & 23 & $05 / 12 / 88$ & 20 & 29 \\
\hline $06 / 10 / 88$ & 21 & 30 & $06 / 11 / 88$ & 21 & 25 & $06 / 12 / 88$ & 21 & 29 \\
\hline $07 / 10 / 88$ & 20 & 30 & $07 / 11 / 88$ & 20 & 24 & $07 / 12 / 88$ & 19 & 30 \\
\hline $08 / 10 / 88$ & 20 & 30 & $08 / 11 / 88$ & 21 & 26 & & & \\
\hline $09 / 10 / 88$ & 21 & 29 & $09 / 11 / 88$ & 21 & 26 & & & - \\
\hline $10 / 10 / 88$ & 20 & 30 & $10 / 11 / 88$ & 23 & 28 & & & - \\
\hline $11 / 10 / 88$ & 21 & 28 & $11 / 11 / 88$ & -- & -- & & & $\cdot$ \\
\hline $12 / 10 / 88$ & 22 & 27 & $12 / 11 / 88$ & 25 & 30 & & & \\
\hline $13 / 10 / 88$ & 20 & 22 & $13 / 11 / 88$ & 20 & 25 & & & \\
\hline $14 / 10 / 88$ & 19 & 23 & $14 / 11 / 88$ & 23 & 28 & & & \\
\hline $15 / 10 / 88$ & 20 & 24 & $15 / 11 / 88$ & 22 & 26 & & & \\
\hline $16 / 10 / 88$ & 19 & 23 & $16 / 11 / 88$ & 23 & 28 & & & \\
\hline $17 / 10 / 88$ & 21 & 27 & $17 / 11 / 88$ & 24 & 28 & & & \\
\hline $18 / 10 / 88$ & 21 & 23 & $18 / 11 / 88$ & 23 & 29 & & & \\
\hline $19 / 10 / 88$ & 21 & 27 & $19 / 11 / 88$ & 24 & 29 & & & \\
\hline $20 / 10 / 88$ & - & -- & $20 / 11 / 88$ & 24 & 29 & & & \\
\hline $21 / 10 / 88$ & 22 & 29 & $21 / 11 / 88$ & 24 & 28 & & & \\
\hline $22 / 10 / 88$ & -- & -- & $22 / 11 / 88$ & 23 & 28 & & & \\
\hline $23 / 10 / 88$ & 21 & 23 & $23 / 11 / 88$ & 24 & 29 & & & \\
\hline $24 / 10 / 88$ & 20 & 25 & $24 / 11 / 88$ & 23 & 27 & & & \\
\hline $25 / 10 / 88$ & 22 & 25 & $25 / 11 / 88$ & 21 & 28 & & & \\
\hline $26 / 10 / 88$ & 20 & 25 & $26 / 11 / 88$ & 22 & 26 & & & \\
\hline $27 / 10 / 88$ & 22 & 26 & $27 / 11 / 88$ & 20 & 24 & & & \\
\hline $28 / 10 / 88$ & 18 & 20 & $28 / 11 / 88$ & 22 & 27 & & & \\
\hline $29 / 10 / 88$ & 21 & 23 & $29 / 11 / 88$ & 20 & 29 & & & \\
\hline $30 / 10 / 88$ & - & -- & $30 / 11 / 88$ & 23 & 28 & & & \\
\hline $31 / 10 / 88$ & 21 & 26 & & & & & & \\
\hline
\end{tabular}

a. Temperaturas minimas

b. Temperaturas máximas 
( continuação )

Apendice 10 - Temperaturas minimas durarte o periodo experimental, ${ }^{\circ} \mathrm{C}$.

\begin{tabular}{|c|c|c|c|c|c|c|c|c|}
\hline \multirow[b]{2}{*}{ Data } & \multirow[b]{2}{*}{$a$} & \multirow[b]{2}{*}{$b$} & \multicolumn{2}{|c|}{ Greche } & \multirow[b]{2}{*}{$t$} & \multirow[b]{2}{*}{ Data } & \multirow[b]{2}{*}{$a$} & \multirow[b]{2}{*}{$b$} \\
\hline & & & Data & $a$ & & & & \\
\hline $25 / 11 / 88$ & 22 & 35 & $01 / 12 / 88$ & 18 & 29 & $01 / 01 / 89$ & 23 & 28 \\
\hline $26 / 11 / 88$ & 19 & 30 & $02 / 12 / 88$ & 20 & 25 & $02 / 01 / 80$ & 22 & 23 \\
\hline $27 / 11 / 88$ & 23 & 31 & $03 / 12 / 88$ & 19 & 28 & $03 / 01 / 89$ & -- & -- \\
\hline $28 / 11 / 88$ & 19 & 30 & $04 / 12 / 88$ & 19 & 29 & $04 / 01 / 89$ & 27 & 28 \\
\hline $29 / 11 / 88$ & 17 & 27 & $05 / 12 / 88$ & 20 & 31 & $05 / 01 / 89$ & $2 ?$ & 28 \\
\hline \multirow[t]{26}{*}{$30 / 11 / 88$} & 18 & 28 & $06 / 12 / 88$ & 21 & 31 & $06-101,89$ & 27 & 30 \\
\hline & & & $07 / 12 / 88$ & 19 & 32 & $07 / 01 / 89$ & 27 & 29 \\
\hline & & & $08 / 12 / 88$ & 19 & 33 & $08 / 01 / 89$ & 25 & 27 \\
\hline & & & $09 / 12 / 88$ & 22 & 30 & $09,01,89$ & 28 & 30 \\
\hline & & & $10 / 12 / 88$ & 18 & 31 & & & \\
\hline & & & $11 / 12 / 88$ & 19 & 30 & & & \\
\hline & & & $12 / 12 / 88$ & 25 & 32 & & & \\
\hline & & & $13 / 12 / 88$ & 25 & 32 & & & \\
\hline & & & $14,12,-88$ & 26 & 28 & & & \\
\hline & & & $15 / 12,88$ & 28 & 29 & & & \\
\hline & & & $16 / 12 / 88$ & 20 & 33 & & & \\
\hline & & & $17 / 12 / 88$ & 21 & 30 & & & \\
\hline & & & $18 / 12 / 88$ & 22 & 31 & & & \\
\hline & & & $19 / 12 / 88$ & 27 & 31 & & & \\
\hline & & & $20 / 12 / 88$ & 30 & 32 & & & \\
\hline & & & $21 / 12 / 88$ & 27 & 33 & & & \\
\hline & & & $22 / 12 / 88$ & 30 & 31 & & & \\
\hline & & & $23 / 12 / 88$ & 28 & 31 & & & \\
\hline & & & $24 / 12 / 88$ & 27 & 32 & & & \\
\hline & & & $25 / 12 / 88$ & 24 & 35 & & & \\
\hline & & & $26 / 12 / 88$ & 28 & 35 & & & \\
\hline & & & $27 / 12 / 88$ & 22 & 28 & & & \\
\hline & & & $28 / 12 / 88$ & 30 & 31 & & & \\
\hline & & & $29 / 12 / 88$ & 29 & 32 & & & \\
\hline & & & $30 / 12 / 88$ & 28 & 30 & & & \\
\hline & & & $31 / 12 / 88$ & 30 & 32 & & & \\
\hline
\end{tabular}

a. Temperaturas minimas

b. Temperaturas máximas 
Apêndice 11 - Consumo diário de ração das matrizes durante o periodo de lactaçăo (CDRM, $k g$ ), peso pre parto (PPF, kos), peso pos parto (PFo, kg) $E$ peso no final da lactaçäo (PL, $k_{0}^{\circ}$ ).

\begin{tabular}{|c|c|c|c|c|c|}
\hline$T r$ & $\mathrm{B1}$ & CDRM & PPP & PPO & PL \\
\hline \multirow[t]{5}{*}{1} & 1 & 5,080 & 282,000 & 262,000 & 250,000 \\
\hline & 2 & 3,869 & 243,000 & 222,500 & 181,800 \\
\hline & 3 & 4,374 & 223,000 & 214,000 & 201,000 \\
\hline & 4 & 4,506 & 276,800 & 254,000 & 223,500 \\
\hline & Iia & 4,457 & 250,200 & 238,125 & 214,075 \\
\hline \multirow[t]{5}{*}{2} & 1 & 4,952 & 280,000 & 272,000 & 252,000 \\
\hline & 2 & 3,942 & 234,500 & 215,000 & 173,000 \\
\hline & 3 & 4,566 & 241,000 & 228,500 & 189,000 \\
\hline & 4 & 4,450 & 275,000 & 241,000 & 227,000 \\
\hline & Iia & 4,478 & 257,025 & 239,125 & 210,250 \\
\hline \multirow[t]{5}{*}{3} & 1 & 4,509 & 228,000 & 224,000 & 207,000 \\
\hline & 2 & 3,658 & 247,000 & 220,000 & 210,100 \\
\hline & 3 & 3,900 & 238,000 & 214,000 & 182,000 \\
\hline & 4 & 4,298 & 228,300 & 207,000 & 175,400 \\
\hline & dia & 4,091 & 235,325 & 216,250 & 193,025 \\
\hline \multirow[t]{5}{*}{4} & 1 & 4,314 & 260,000 & 264,000 & 248,000 \\
\hline & 2 & 3,022 & 249,000 & 221,000 & 186,800 \\
\hline & 3 & 4,373 & 254,000 & 229,000 & 200,000 \\
\hline & 4 & 4,289 & 262,700 & 235,800 & 212,000 \\
\hline & dia & 4,000 & 257,925 & 237,450 & 213,200 \\
\hline \multirow[t]{5}{*}{5} & 1 & 4,892 & 285,000 & 258,000 & 221,000 \\
\hline & 2 & 3,000 & 292,000 & 262,000 & 204,800 \\
\hline & 3 & 4,577 & 275,000 & 254,000 & 225,000 \\
\hline & 4 & 4,262 & 262,000 & 250,000 & 232,700 \\
\hline & dia & 4,183 & 278,500 & 256,000 & 220,875 \\
\hline \multirow[t]{5}{*}{6} & 1 & 5,131 & 269,000 & 253,000 & 234,000 \\
\hline & 2 & 3,781 & 269,000 & 255,000 & 219,700 \\
\hline & 3 & 4,080 & 255,000 & 240,000 & 212,000 \\
\hline & 4 & 4,206 & 278,000 & 257.000 & 228,000 \\
\hline & dia & 4,300 & 267,750 & 251,250 & 223,425 \\
\hline \multirow[t]{5}{*}{7} & 1 & 4,727 & 296,000 & 251,000 & 233,000 \\
\hline & 2 & 3,970 & 272,000 & 254,500 & 207,500 \\
\hline & 3 & 4,140 & 276,000 & 260,000 & 243,000 \\
\hline & 4 & 3,747 & 228,000 & 208,000 & 190,000 \\
\hline & iia & 4,146 & 268,000 & 243,375 & 218,375 \\
\hline \multirow[t]{5}{*}{8} & 1 & 4,585 & 202,000 & 249,000 & 223,000 \\
\hline & 2 & 3,080 & 241,000 & 225,000 & 200,000 \\
\hline & 3 & 3,844 & 307,000 & 288,000 & 282,800 \\
\hline & 4 & 4,240 & 250,500 & 230,000 & 194,000 \\
\hline & ia & 4,091 & 265,125 & 248,000 & 224,950 \\
\hline
\end{tabular}


Apendice 12 - Determinações individuais e valores médios de imunoglobulinas séricas (unidades ZST) de leitores submetidos ao tratamento Ti $(14.4 \%$ de leite peletizado).

Época de Amostragem (dias)

\begin{tabular}{|c|c|c|c|c|c|c|c|c|}
\hline 1 & Noleitão & 1 & 2 & 10 & 21 & 28 & 35 & 01 \\
\hline \multirow[t]{6}{*}{1} & L1 & 35,5 & 30,0 & 27,5 & 33,0 & 28,0 & 25,5 & 32,0 \\
\hline & $\mathrm{L} 2$ & 44,0 & 37,0 & 31,0 & 32,0 & 26,5 & 31,0 & 33,0 \\
\hline & L3 & 36,5 & $3 ?, 5$ & 36,0 & 25,5 & 19,0 & 22,0 & 31,0 \\
\hline & L4 & 32,0 & 35,0 & 34,0 & 30,5 & 26,5 & 25,0 & 29,5 \\
\hline & L5 & 29,0 & 31,0 & 28,5 & 30,5 & 24,0 & 25,5 & 30,5 \\
\hline & Média & 35,4 & 34,1 & 31,4 & 30,3 & 24,8 & 25,8 & 31,2 \\
\hline \multirow[t]{6}{*}{2} & L1 & 21,0 & 21,0 & 21,5 & 23,5 & 22,5 & 28,0 & 33,5 \\
\hline & L2 & 26,0 & 32,0 & 28,5 & 28,0 & 28,5 & 25,5 & 27,5 \\
\hline & L3 & 20,0 & 16,0 & 20,0 & 23,5 & 23,5 & 23,5 & 22,5 \\
\hline & L4 & 28,0 & 33,0 & 35,0 & 38,0 & 24,5 & 24,0 & 26,0 \\
\hline & L5 & 28,5 & 24,0 & 27,0 & 26,0 & 19,0 & 30,0 & 31,0 \\
\hline & Média & 24,7 & 25,2 & 26,4 & 27,8 & 23,0 & 26,2 & 28,1 \\
\hline \multirow[t]{6}{*}{3} & L1 & 23,5 & 22,5 & 26,5 & 20,5 & 19,5 & 20,0 & 28,5 \\
\hline & L2 & 19,5 & 23,0 & 23,5 & 19,5 & 18,0 & 20,5 & 24,0 \\
\hline & L3 & 25,0 & 27,5 & 22,5 & 22,5 & 15,0 & 21,5 & 26,0 \\
\hline & L4 & 30,0 & 32,0 & 24,0 & 22,0 & 22,5 & 22,5 & 25,0 \\
\hline & L5 & 32,0 & 36,0 & 32,5 & 23,5 & 25,0 & 24,0 & 30,5 \\
\hline & Media & 20,0 & 28,2 & 25,8 & 21,6 & 20,0 & 21,7 & 20,8 \\
\hline \multirow[t]{8}{*}{4} & L1 & 28,0 & 34,5 & 24,5 & 23,0 & 21,0 & 23,0 & 27,0 \\
\hline & $\mathrm{LZ}$ & 32,0 & 33,0 & 22,0 & 19,5 & 16,0 & 15,0 & 23,5 \\
\hline & L3 & 28,0 & 29,5 & 19,0 & 20,0 & 22,5 & 21,5 & 28,0 \\
\hline & L4 & 27,5 & 29,5 & 15,0 & 21,5 & 21,5 & 25,0 & 32,5 \\
\hline & LE & 33,0 & 29,5 & 21,5 & 25,5 & 25.0 & 26,0 & 20,0 \\
\hline & L6 & 36,5 & 34,0 & 22,0 & 19,0 & 25,0 & 19,0 & 24,0 \\
\hline & Média & 30,8 & 31,7 & 20,7 & 21,4 & 21,8 & 21,6 & 27,2 \\
\hline & Média & 29,2 & 29,8 & 26,1 & 25,3 & 22,6 & 23,8 & 28,3 \\
\hline
\end{tabular}


118.

\begin{abstract}
Apéndice 13 - Determinaçôes individuais e valores médios de imunoglobulinas séricas (unidades ZST) de leitós submetidos ao tratamento T4 $19,6 \%$ lelte peletizados.
\end{abstract}

Epoca de Amostragem (dias)

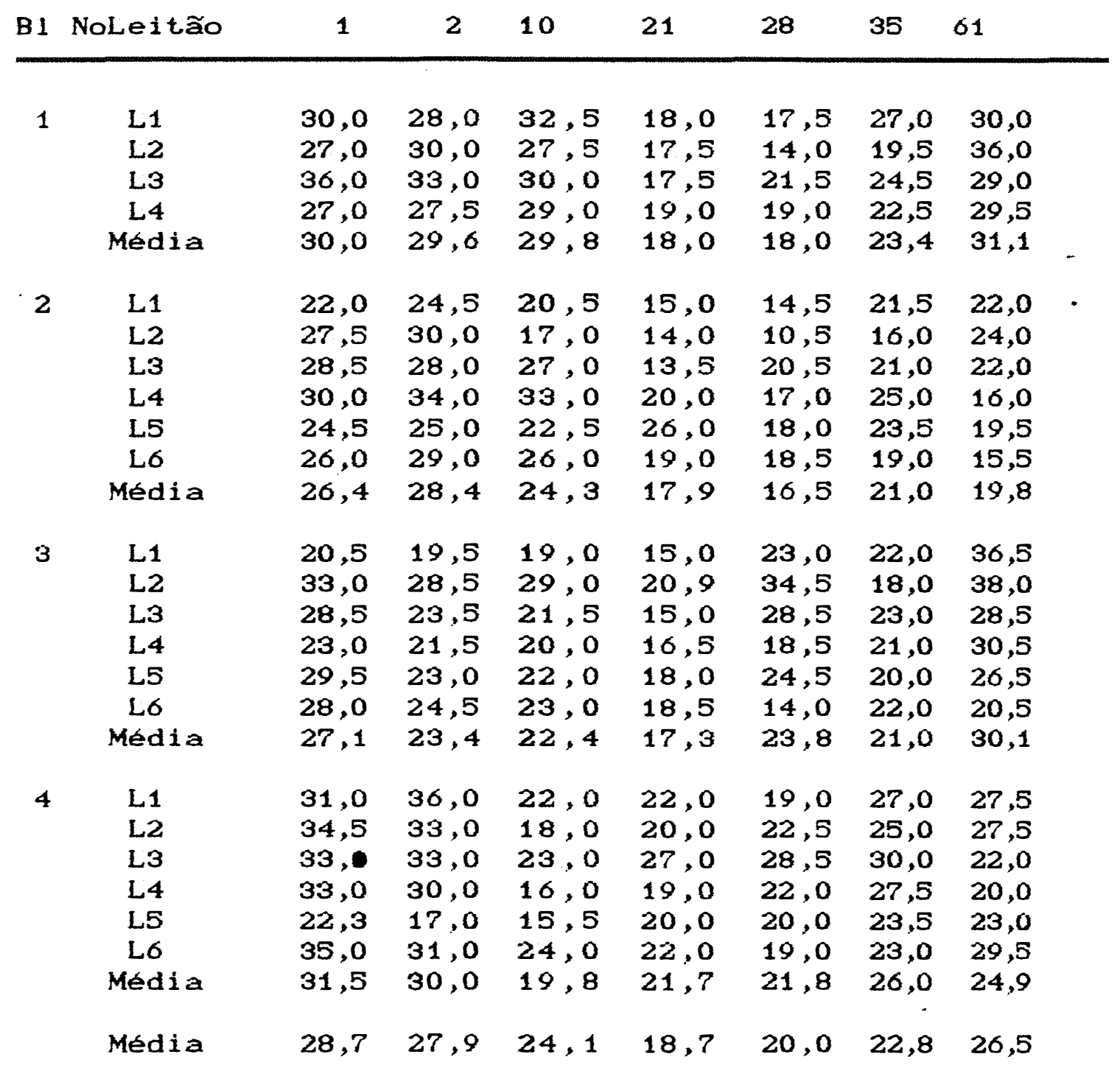




\begin{abstract}
Apèndice 14 - Determinações individuais e valores medios de imunoglobulinas sericas (unidades ZST) de leitöes submetidos ao tratamento To Cdieta líquida com raçào peletizada).
\end{abstract}

Época de Amostragem (dias)

\begin{tabular}{|c|c|c|c|c|c|c|c|c|}
\hline B 1 & Noleitão & 1 & 2 & 10 & 21 & 28 & 35 & 81 \\
\hline \multirow[t]{6}{*}{1} & L1 & 28,0 & 32,5 & 25,5 & 24,0 & 18,5 & 23,0 & 25,0 \\
\hline & L̈̈ & 27,0 & 32,0 & 20,5 & 22,0 & 20,0 & 22,0 & 26,5 \\
\hline & L3 & 33,0 & 34,0 & 30,0 & 24,5 & 17,0 & 21,5 & 26,0 \\
\hline & L4 & 40,0 & 38,5 & 29,0 & 24,5 & 18,0 & 20,0 & 30,0 \\
\hline & L5 & 30,0 & 32,0 & 26,5 & 26,5 & 19,0 & 21,0 & 30,5 \\
\hline & Media & 31,6 & 33,8 & 27,5 & 24,3 & 18,5 & 21,5 & 27,0 \\
\hline \multirow[t]{7}{*}{2} & L1 & 30,0 & 32,0 & 24,5 & 19,0 & 20,0 & 14,5 & 26,0 \\
\hline & L2 & $2 ?, 5$ & 29,0 & 29,0 & 27,0 & 23,5 & 21,5 & 36,0 \\
\hline & L3 & 31,0 & 35,0 & 29,0 & 24,5 & 24,5 & 24,0 & 29,0 \\
\hline & L4 & 33,0 & 34,5 & 20,0 & 26,0 & 25,5 & 19,0 & 37,0 \\
\hline & L5 & 28,0 & 37,0 & 25,5 & 22,0 & 15,0 & 22,0 & 30,0 \\
\hline & L6 & 32,0 & 32,5 & 28,5 & 20,5 & 22,5 & 20,0 & 35,0 \\
\hline & Media & 30,3 & 33,3 & 27,1 & 23,2 & 21,8 & 20,2 & 32,2 \\
\hline \multirow[t]{6}{*}{3} & L1 & 26,0 & 26,5 & 24,0 & 25,5 & 23,0 & 25,0 & 28,0 \\
\hline & $\mathrm{L2}$ & 28,0 & 30,0 & 32,0 & 23,5 & 32,0 & 27,0 & 24,5 \\
\hline & L3 & 31,0 & 27,0 & 31,0 & 24,0 & 24,0 & 28,0 & 26,5 \\
\hline & $L 4$ & 30,0 & 31,5 & 31,5 & 25,5 & 24,0 & 15,5 & 27,5 \\
\hline & L5 & 32,0 & 30,5 & 32,5 & 25,5 & 23,0 & 17,5 & 30,0 \\
\hline & Média & 30.6 & 29,1 & 30,2 & 24,8 & 25,2 & 22,6 & 27,3 \\
\hline \multirow[t]{7}{*}{4} & L 1 & 31,0 & 19,0 & 21,0 & 20,5 & 18,0 & 23,0 & 30,5 \\
\hline & $\mathrm{L2}$ & 31,0 & 25,5 & 18,0 & 24,0 & 19,0 & 20.5 & 34,5 \\
\hline & L3 & 29,0 & 25,0 & 21,5 & 22,5 & 18,0 & 24,0 & 27,0 \\
\hline & L4 & 25,0 & 23,0 & 17,0 & 22,5 & 22,5 & 30,0 & 31,0 \\
\hline & L5 & 24,0 & 19,5 & 25,0 & 20,5 & 11,0 & 22,0 & 29,0 \\
\hline & Media & 28,0 & 22,4 & 20,6 & 22,0 & 17,7 & 25,1 & 30,4 \\
\hline & Média & 30,1 & 29,7 & 26,3 & 23,6 & 20,8 & 22,3 & 29,4 \\
\hline
\end{tabular}


Apéndice 15 - Determinações individuais e valores médios de imunoglobulinas sericas (unidades ZST) dE leitöes submetidos ao tratamento T8 controle leite peletizados.

Epoca de Amostragem (dias)

\begin{tabular}{|c|c|c|c|c|c|c|c|c|}
\hline $\mathrm{B} 1$ & Noleitão & 1 & 2 & 10 & 21 & 28 & 35 & 61 \\
\hline \multirow[t]{6}{*}{1} & L1 & 34,0 & 34,0 & 32,5 & 30,5 & 24,5 & 27,5 & 29,5 \\
\hline & $\mathrm{L} 2$ & 30,0 & 28,0 & 24,0 & 24,0 & 24,5 & 20,5 & 21,0 \\
\hline & L3 & 34,0 & 38,0 & 20,0 & 27,5 & 28,0 & 23,0 & 27,5 \\
\hline & L4 & 28,5 & 32,0 & 23,0 & 22,0 & 19,5 & 29,5 & 28,0 \\
\hline & L5 & 24,5 & 28,0 & 25,0 & 27,0 & 25,5 & 30,5 & 24,0 \\
\hline & Média & 30,2 & 32,0 & 24,9 & 20,2 & 24,4 & 27,4 & 26,0 \\
\hline \multirow[t]{7}{*}{2} & L1 & 26,0 & 36,0 & 31,5 & 29,5 & 29,0 & 24,5 & 36,0 \\
\hline & $\mathrm{L} 2$ & 25,0 & 28,0 & 32,0 & 27,0 & 24,0 & 17,5 & 31,0 \\
\hline & L3 & 27,5 & 31,0 & 28,5 & 26,0 & 23,0 & 21,5 & 33,5 \\
\hline & $\mathrm{L}_{4}$ & 28,0 & 31,0 & 33,0 & 24,0 & 21,5 & 18,5 & 34,0 \\
\hline & LS & 30,0 & 30,0 & 32,5 & 29,0 & 25,0 & 25,0 & 33,0 \\
\hline & L6 & 27,0 & 35,0 & 29,5 & 27,0 & 18,0 & 27,5 & 26,0 \\
\hline & Média & 27,3 & 31,8 & 31,2 & 27,1 & 23,4 & 22,4 & 32,3 \\
\hline \multirow[t]{6}{*}{3} & L1 & 40,0 & 31,5 & 33,0 & 28,0 & 29,0 & 24,0 & 26,0 \\
\hline & $\mathrm{L2}$ & 35,5 & 28,0 & 33,5 & 26,0 & 22,0 & 26,5 & 27,5 \\
\hline & L3 & 24,0 & 26,5 & 28,0 & 26,5 & 18,0 & 29,5 & 27,0 \\
\hline & L4 & 32,5 & 32,0 & 27,0 & 25,5 & 24,0 & 27,5 & 28,0 \\
\hline & L5 & 40,0 & 35,0 & 33,0 & 35,5 & 19,5 & 21,0 & 33,0 \\
\hline & Média & 34,4 & 30,6 & 30,9 & 28,3 & 22,5 & 25,7 & 28,3 \\
\hline \multirow[t]{8}{*}{4} & $L_{1}$ & 34,0 & 27,0 & 27,0 & 34,5 & 20,5 & 29,0 & 27,0 \\
\hline & $\mathrm{L} 2$ & 25,0 & 24,0 & 23,5 & 25,0 & 21,5 & 26,0 & 31,0 \\
\hline & L3 & 40,0 & 33,0 & 20,5 & 20,0 & 28,0 & 31,5 & 26,5 \\
\hline & L4 & 37,0 & 30,0 & 26,5 & 23,0 & 24,5 & 29,0 & 28,5 \\
\hline & L5 & 40,0 & 33,0 & 30,0 & 30,0 & 20,0 & 25,0 & 29,0 \\
\hline & L6 & 39,0 & 30,5 & 24,5 & 25,5 & 22,5 & 25,5 & 23,5 \\
\hline & Média & 35,8 & 30,6 & 20,3 & 27,3 & 22,8 & 27,7 & 27,6 \\
\hline & Media & 31,9 & 31,3 & 28,3 & 27.2 & 23,3 & 25.8 & 28.5 \\
\hline
\end{tabular}


121.

Apèndice 16 - Valores médios obtidos a partir das determinações individuais de imunoglobulinas sèricas (unidades ZST) de leitöes.

Época de Amostragem (dias)

$\begin{array}{lllllllll}\text { Tr B1 No } & 1 & 2 & 10 & 21 & 28 & 35 & 61 & \text { Media } \\ \text { Leităo } & & 10 & & \end{array}$

315

25

35

46

Média

$\begin{array}{ll}1 & 4 \\ 2 & 0 \\ 3 & 6 \\ 4 & 6\end{array}$

Média

6

$\begin{array}{ll}1 & 5 \\ 2 & 6 \\ 3 & 5 \\ 4 & 6\end{array}$

$\begin{array}{ll}35,4 & 34,1 \\ 24,7 & 25,2 \\ 26,0 & 28,2 \\ 30,8 & 31,7 \\ 20,2 & -20,8\end{array}$

$31,430,3$

$26,427,8$

$25,8 \quad 21,6$

$20,7 \quad 21,4$

26,1

25,3

24,8

23,0

20,0

21,8

22,6

25,8

26,2

21,7

$21,6 \quad 27,2$

$23,8 \quad 28,3$

26,4

$30,0 \quad 29,6$

$26,4 \quad 28,4$

$27,1 \quad 23,4$

$31,5 \quad 30,0$

29,8

24,3

22,4

19,8

18,0

17,9

17,3

21,7

18,0

16,5

23,8

21,9

$23,4 \quad 31,1$

$21,0 \quad 19,8$

$21,0 \quad 30,1$

$26,0 \quad 24,9$

$22,9 \quad 26,5$

24,1

Média

$$
31,6 \quad 33,8
$$

$30,3 \quad 33,3$

$$
30,6 \quad 29,1
$$

$28,0 \quad 22,4$

$27,5 \quad 24,3$

$27,123,2$

$30,2 \quad 24,8$

$20,622,0$

$26,4 \quad 23,6$

18,5

21,8

25,2

$17, ?$

20,8

$21,527,6$

$20,2 \quad 32,2$

$22,6 \quad 27,3$

$25,130,4$

$22,4 \quad 29,4 \quad 26,0$

8

$$
\begin{array}{ll}
1 & 5 \\
2 & 6
\end{array}
$$

30

27,3

32,0

24,

26,

24,4

$27,426,0$

31,2

27,1

28,3

23,4

22,5

22,8

$26,327,3$

22,4

$25,7 \quad 28,3$

$27,7 \quad 27,6$

31,0
28,3

27,2

23,3

Média

31,3

()

23
21,
$25,8 \quad 28,0$

28,0

Media
$30,0 \quad 29,6$ 
122.

Apéndice 17 - Análise de variáncia do ganho diário de peso (GDP) de 21 a 28 dias, com ajuste por covariância para o peso médio inicial aos 21 dias.

\begin{tabular}{|c|c|c|c|c|c|}
\hline Causa de Variação & G.L & S.Q. & Q.M. & $F^{a}$ & Nivel $\%$ \\
\hline Tratamento & 7 & 0,0373 & 0,0053 & 2,07 & 9,48 \\
\hline Trat. A justado & 7 & 0,0247 & 0,0035 & $1,37_{-4}^{n s}$ & 26,92 \\
\hline Contraste $1^{b}$ & 1 & $9 \times 10^{-7}$ & $9 \times 10^{-7}$ & $4 \times 10^{-4}$ & 98,26 \\
\hline Contraste $2^{c}$ & 1 & 0,0128 & 0,0128 & $4,97^{*}$ & 3,55 \\
\hline Contraste $3^{d}$ & 1 & 0,0029 & 0,0029 & $1,14^{n s}$ & 29,87 \\
\hline Contraste $4^{\ominus}$ & 1 & 0,0032 & 0,0032 & $1,26^{n s}$ & 27,40 \\
\hline Contraste $5^{f}$ & 1 & 0,0032 & 0,0032 & $1,26^{n s}$ & 27,43 \\
\hline Contraste $\sigma^{9}$ & 1 & 0,0020 & 0,0020 & $0,78^{n s}$ & 60,77 \\
\hline Contraste $7^{h}$ & 1 & 0,0014 & 0,0014 & $0,54^{n s}$ & 52,21 \\
\hline Bloco & 3 & 0,0346 & & & \\
\hline Residuo & 21 & & & & \\
\hline Regressão & 1 & 0,0007 & & & \\
\hline Res. A justado & 20 & 0,0514 & 0,0025 & & \\
\hline Total & 31 & 0,1241 & & & \\
\hline
\end{tabular}

a. ns = não significativo, * $=\mathbf{P}<0,05, * *=\mathbf{P}<0,01$ * $\theta_{* *}^{*}=\mathbf{P}<0,001$

b. $\mathbf{T} 1+\mathrm{T} 2+\mathrm{T} 3+\mathbf{T} 4+\mathrm{T} 5+\mathrm{T} \sigma$ versus $\mathbf{T 7}+\mathrm{TB}$

c. $T$ r versus $\mathbf{T B}$

d. $\mathrm{T} 1+\mathrm{T} 2+\mathrm{T} 9+\mathrm{T} 4$ versus $\mathrm{T} 5+\mathrm{T} 6$

e. $\mathrm{T} 1+\mathrm{T} 2$ versus $\mathbf{T} 3+\mathrm{T} 4$

f. $\mathbf{T 1}+\mathrm{T} 3$ versus $\mathbf{T 2}+\mathrm{T} 4$

g. $\mathbf{T} 1+\mathbf{T} 4$ versus $\mathbf{T} 2+\mathbf{T} 3 \mathrm{I}$

h. TS versus To

Coeficiente de variação $=24,93 \%$

Média geral ajustada $=0,203$ 
123.

Apendice 18 - Análise de variáncia do Ganho diário de peso (GDP) de 28 a 35 dias, com ajuste por covariancia para o peso médio inicial aos 28 dias.

\begin{tabular}{|c|c|c|c|c|c|}
\hline Causa de Variação & G.L. & S.Q. & Q. M. & $F^{a}$ & Nivel $\%$ \\
\hline Tratamento & 7 & 0,0163 & 0,0023 & 0,91 & 52,17 \\
\hline Trat. A justado & 7 & 0,0160 & 0,0023 & $0,89^{\text {ns }}$ & 52,96 \\
\hline Contraste $1^{b}$ & 1 & 0,0057 & 0,0057 & $2,24^{n s}$ & 14,73 \\
\hline Contraste $2^{c}$ & 1 & 0,0001 & 0,0001 & $0,05^{n s}$ & 82,19 \\
\hline Contraste $3^{d}$ & 1 & 0,0060 & 0,0060 & $2,58^{n s}$ & 12,04 \\
\hline Contraste $4^{e}$ & 1 & 0,0000 & 0,0000 & $0,00^{n s}$ & 99,29 \\
\hline Contraste $5^{1}$ & 1 & 0,0015 & 0,0015 & $0,57^{n s}$ & 53,54 \\
\hline Contraste $6^{9}$ & 1 & 0,0021 & 0,0021 & $0,82^{n 8}$ & 62,16 \\
\hline Contraste $7^{h}$ & 1 & $9 \times 10^{-0}$ & $9 \times 10^{-0}$ & $0,004^{n s}$ & 95,23 \\
\hline B loco & 3 & 0,0461 & & & \\
\hline Residuo & 21 & & & & \\
\hline Regressão & 1 & 0,0053 & & & \\
\hline Res. A justado & 20 & 0,0512 & 0,0026 & & \\
\hline $\begin{array}{l}\text { Total } \\
\text { Total }\end{array}$ & 31 & 0,1189 & ------- & & \\
\hline
\end{tabular}

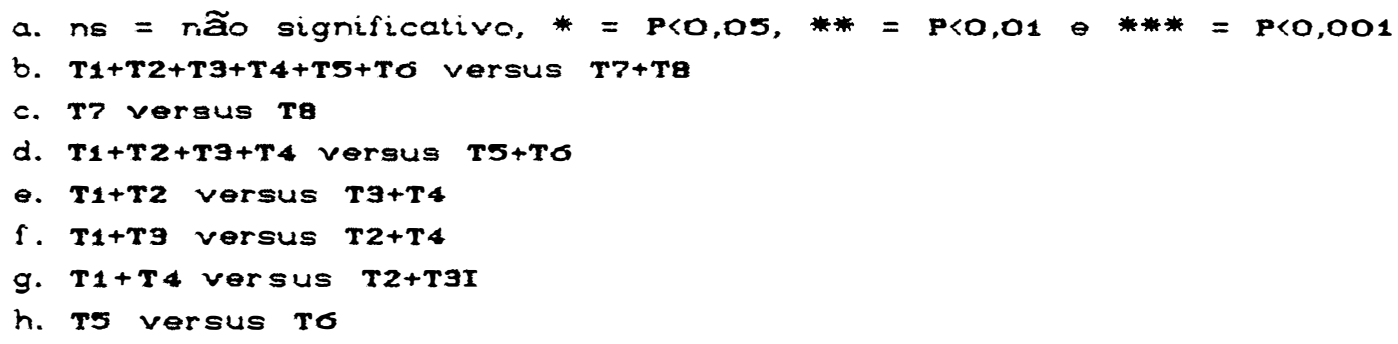


124.

Apéndice 19 - Análise de variáncia do ganho diário de peso (GDP) de 42 a 49 dias, com ajuste por covariáncia para o peso médio inicial aos 42 dias.

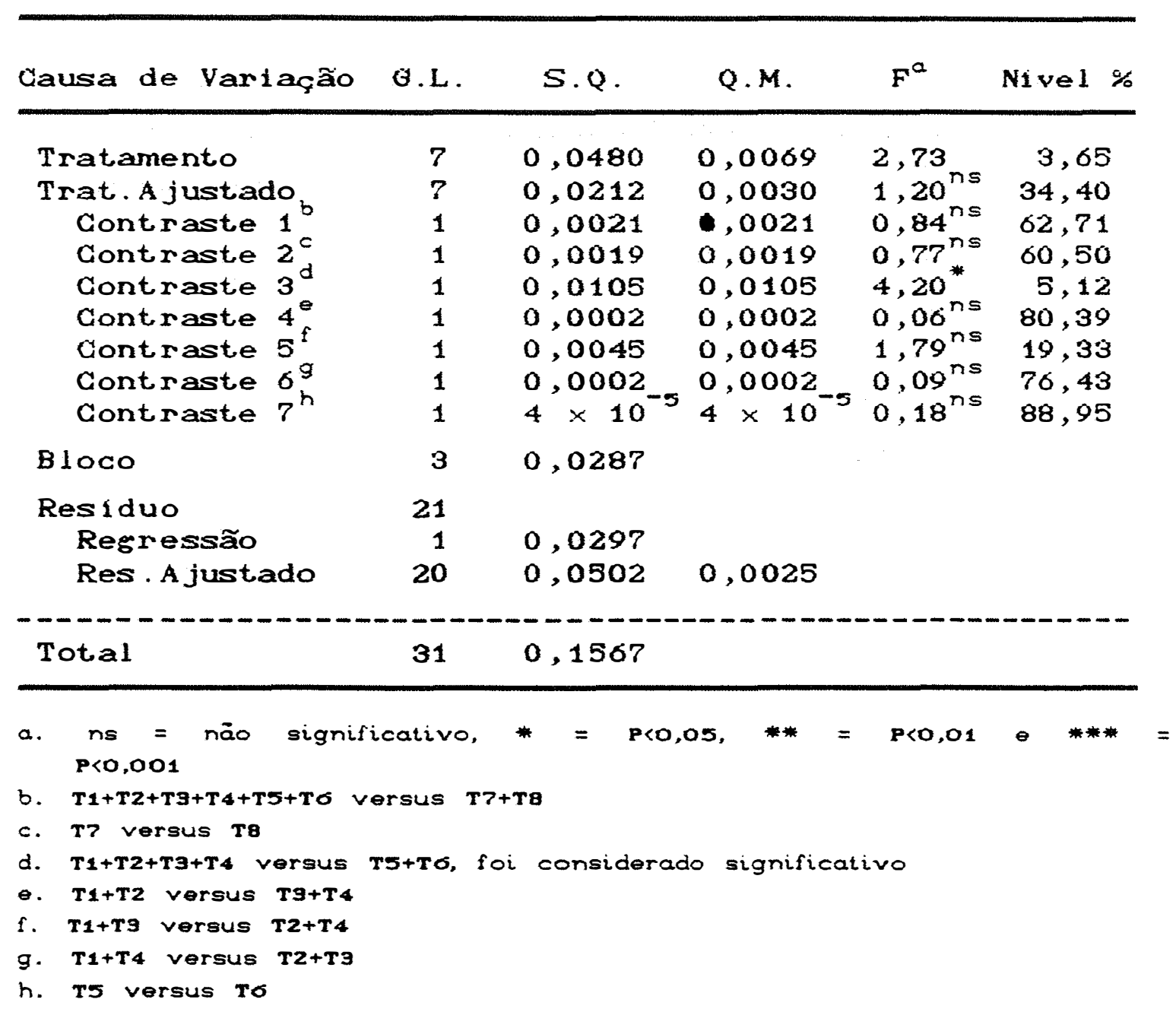

Coeficiente de variação $=12,45 \%$

Média geral ajustada $=0,403$ 
125.

Apéndice 20 - Análise de variancia do canho diário de pano (GDP) de 21 a 49 dias, com ajuste por covariáncia para o peso médio inicial aos 21 dias.

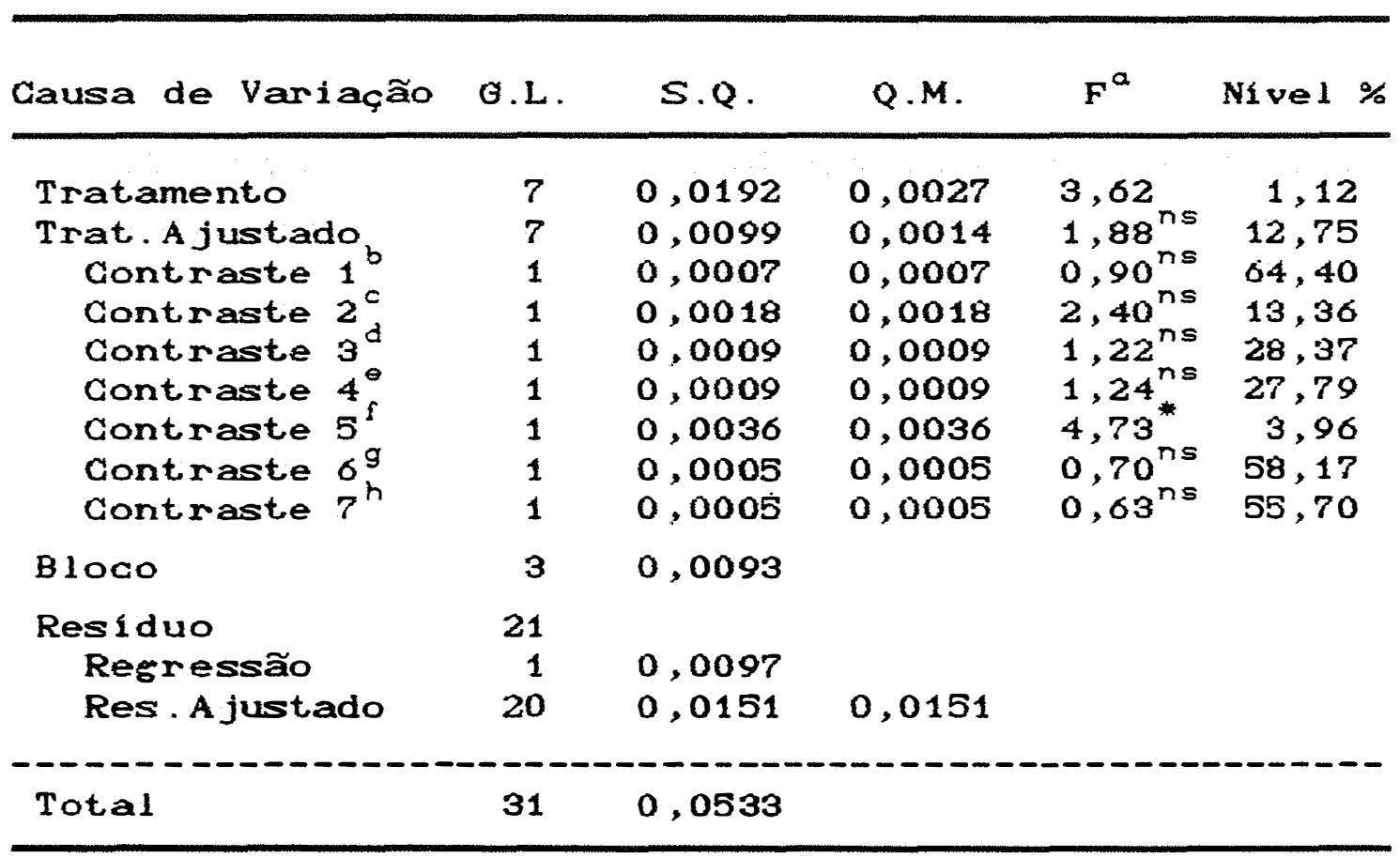

a. ns = não significativo, * $=\mathbf{P}<0,05, * *=\mathbf{P}<0,01$ e $* * *=P<0,001$

b. $\mathbf{T} 1+\mathbf{T} 2+\mathbf{T} 3+\mathbf{T} 4+\mathrm{T} 5+\mathrm{T} \sigma$ versus $\mathbf{T} 7+\mathbf{T B}$

c. Tr versus TB

d. $\mathrm{T} 1+\mathrm{T} 2+\mathrm{T} 3+\mathrm{T} 4$ versus $\mathrm{T} 5+\mathrm{T} \sigma$

e. $T_{1}+T_{2}$ versus $T_{3}+T_{4}$

f. $\mathbf{T} 1+\mathbf{T} 3$ versus $\mathbf{T 2}+\mathbf{T} 4$

g. $\mathbf{T} 1+\mathrm{T} \&$ versus $\mathbf{T 2}+\mathrm{T} 9 \mathrm{I}$

h. Ts versus To

Coeficiente de variação $=11,66 \%$

Média seral ajustada $=0,236$ 
Apéndice 21 - Análise de variáncia do consumo diário de ração (CDR) de 21 a 28 dias, com ajuste por covariancia para o peso médio inicial aos 21 dias.

\begin{tabular}{|c|c|c|c|c|c|}
\hline Causa de Variação & G.L. & $S . Q$ & $Q \cdot M$. & $F^{a}$ & Nivel\% \\
\hline $\begin{array}{l}\text { Tratamento } \\
\text { Trat. A justado } \\
\text { Contraste } 1^{b} \\
\text { Contraste } 2^{c} \\
\text { Contraste } 3^{d} \\
\text { Contraste } 4^{\circ} \\
\text { Contraste } 5^{r} \\
\text { Contraste } 6^{g} \\
\text { Contraste } 7^{h}\end{array}$ & $\begin{array}{l}7 \\
7 \\
1 \\
1 \\
1 \\
1 \\
1 \\
1 \\
1\end{array}$ & $\begin{array}{l}0,0041 \\
0,0041 \\
0,0006 \\
3 \times 10^{-5} \\
0,0029 \\
4 \times 10^{-5} \\
0,0005-5 \\
2 \times 10^{-5} \\
9 \times 10^{-6}\end{array}$ & $\begin{array}{l}0,0006 \\
0,0006 \\
0,0006 \\
3 \times 10^{-5} \\
0,0029 \\
4 \times 10^{-5} \\
0,0005-5 \\
2 \times 10^{-5} \\
9 \times 10^{-0}\end{array}$ & $\begin{array}{l}10,51^{* *} \\
10,52^{* *} \\
11,09^{* *} \\
0,52^{n s} \\
51,52^{* *} \\
0,64^{n s} \\
8,72^{* *} \\
0,31^{n s} \\
0,16^{n s}\end{array}$ & $\begin{array}{c}0,007 \\
0,007 \\
0,36 \\
51,54 \\
0,001 \\
56,00 \\
0,78 \\
58,79 \\
69,53\end{array}$ \\
\hline B 10 co & 3 & 0,0002 & & & \\
\hline $\begin{array}{l}\text { Resíduo } \\
\text { Regressão } \\
\text { Res. A justado }\end{array}$ & & $\begin{array}{l}5 \times 10^{-6} \\
0,0011\end{array}$ & $6 \times 10^{-5}$ & & \\
\hline Total & 31 & 0,0054 & --- & & \\
\hline 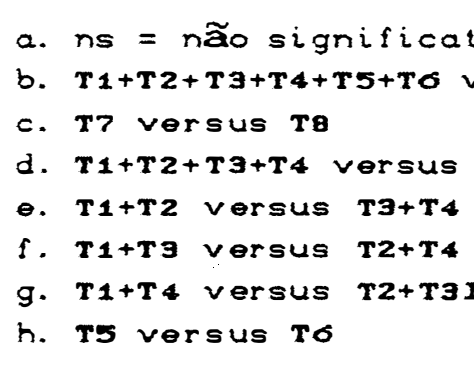 & $\begin{array}{l}\text { ivo, * } \\
\text { ersus } \\
\text { TS+To }\end{array}$ & $\begin{array}{l}\mathbf{P}<0,05, \\
\mathrm{~TB}\end{array}$ & $=\mathbf{P}<0,01$ & $e *$ & $P<0,001$ \\
\hline
\end{tabular}

Coeficiente de variação $=55,94 \%$

Média seral ajustada $=0,013$ 
Apêndice 22 - Análise de variancia do consumo diário de raçäo (CDR) de 28 a 35 dias, com ajuste por covariància para o peso médio inicial aos 28 dias.

\begin{tabular}{|c|c|c|c|c|c|}
\hline Causa de Variação & G.L. & $S . Q$. & $Q . M$. & $F^{a}$ & Nive 1 \\
\hline Tratamento & 7 & 0,0364 & 0,0052 & $4,33^{*}$ & 0,48 \\
\hline Trat A justado & $?$ & 0,0261 & 0,0037 & $3,10^{*}$ & 2,20 \\
\hline Cont raste 1 & 1 & 0,0067 & 0,0067 & $5,5 \varphi^{*}$ & 2,68 \\
\hline Contraste $2^{c}$ & 1 & 0,0004 & 0,004 & $0,40^{n=}$ & 54,01 \\
\hline Cont raste $3^{d}$ & 1 & 0,0159 & 0,0150 & $13,23^{*}$ & 0,19 \\
\hline Cont raste $4^{\circ}$ & 1 & $1 \times 10^{-0}$ & $1 \times 10^{-6}$ & $0,00^{n s}$ & 97,40 \\
\hline Contraste $5^{f}$ & 1 & 0,0010 & 0,0010 & $0,80^{n s}$ & 03,34 \\
\hline Contraste $0^{9}$ & 1 & 0,0009 & 0,0009 & $0,75^{n s}$ & 59,97 \\
\hline Contraste $7^{h}$ & 1 & $4 \times 10^{-6}$ & $4 \times 10^{-6}$ & $0,00^{n s}$ & 95,56 \\
\hline B 1000 & 3 & 0,0030 & & & \\
\hline Residuo & 21 & & & & \\
\hline Reoressão & 1 & 0,0084 & & & \\
\hline Res. A justado & 20 & 0,0240 & 0,0012 & & \\
\hline \multicolumn{6}{|c|}{ 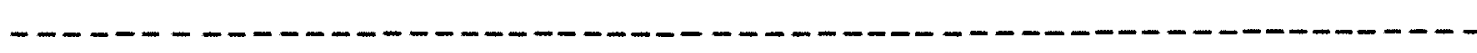 } \\
\hline Total & 31 & 0,0720 & & & \\
\hline
\end{tabular}

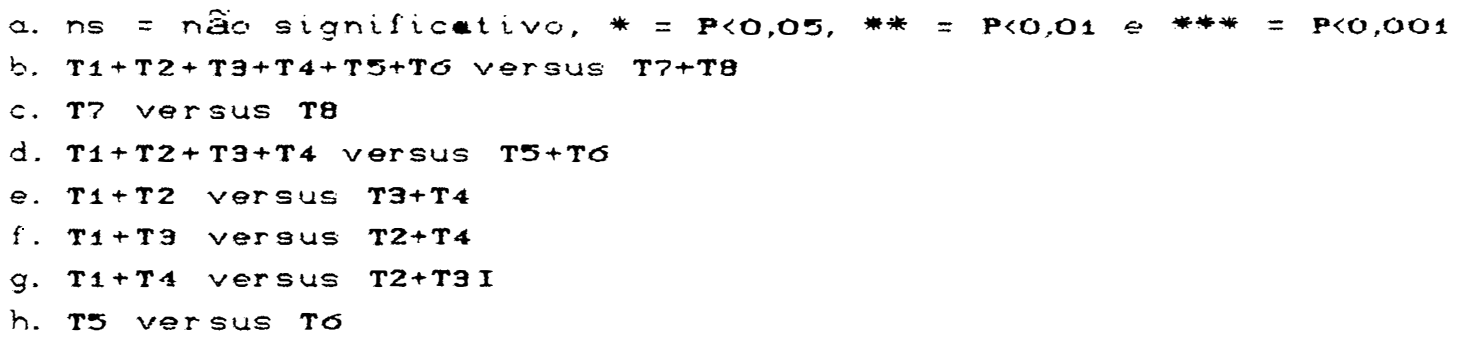


128.

Apéndice 23 - Análise de variancia do consumo diario de raçäo (CDR) de 35 a 42 dias, com ajuste por covariáncia para o peso médio inicial aos 35 dias.

\begin{tabular}{|c|c|c|c|c|c|}
\hline Causa de Variação & G.L. & 5. & Q.M. & $F^{a}$ & Nivel $\%$ \\
\hline Tratamento & 7 & 0,1004 & 0,0152 & $4,62^{* *}$ & 0,36 \\
\hline Trat. A justado, & 7 & 0,0768 & 0,0110 & $3,33^{*}$ & 1,01 \\
\hline Contraste $1^{b}$ & 1 & 0,0145 & 0,0145 & $4.40^{*}$ & 4,65 \\
\hline Contraste $2^{\circ}$ & 1 & 0,0009 & 0,0009 & $0,27^{n s}$ & 01,58 \\
\hline Cont raste $3^{d}$ & 1 & 0,0505 & 0,0505 & $15,35^{* *}$ & 0,11 \\
\hline Contraste $4^{\circ}$ & 1 & 0,0026 & 0,0026 & $0,78^{n s}$ & 00,92 \\
\hline Contraste $5^{f}$ & 1 & 0,0040 & 0,0040 & $1,22^{n s}$ & 28,32 \\
\hline Contraste $\sigma^{9}$ & 1 & 0,0006 & 0,0006 & $0,18^{n s}$ & 67,47 \\
\hline Cont raste $7^{h}$ & 1 & 0,0001 & 0,0001 & $0,04^{n s}$ & 83,75 \\
\hline Bloco & 3 & 0,0509 & & & \\
\hline Residuo & 21 & & & & \\
\hline Regressão & 1 & 0,0309 & & & \\
\hline Res. A justado & 20 & 0,0659 & 0,0033 & & \\
\hline 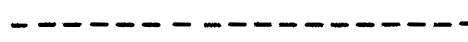 & - & ------ & $----1 \quad r$ & - & ------ \\
\hline Total & 31 & 0,2540 & & & \\
\hline
\end{tabular}

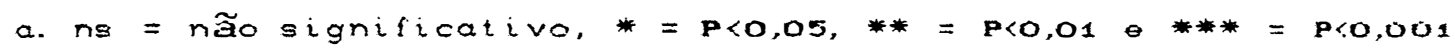

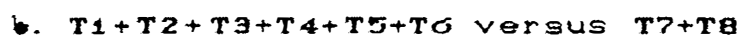

c. Tr versus ro

d. $\mathbf{T}_{1}+\mathrm{T}_{2}+\mathrm{T}_{3}+\mathrm{T} 4$ versus $\mathrm{T} 5+\mathrm{TO}$

e. $\mathbf{T}_{1}+\mathbf{T} 2$ versus $\mathbf{T} \mathbf{3}+\mathbf{T} 4$

f. $\mathbf{T}_{1}+\mathbf{T}_{3}$ versus $\mathbf{T} 2+\mathrm{T}_{4}$

g. $\mathbf{T}_{1}+\mathbf{T} 4$ versus $\mathbf{T} 2+\mathbf{T} 3 \mathbf{I}$

h. Ts versus To

Coeficiente de variação $=15,23 \%$

Média seral ajustada $=0,377$ 
Apendice 24 - Analise de variancia do consumo diario de ração (CDR) de 42 a 49 dias, com ajuste por covariancia para o peso medio inicial aos 42 dias.

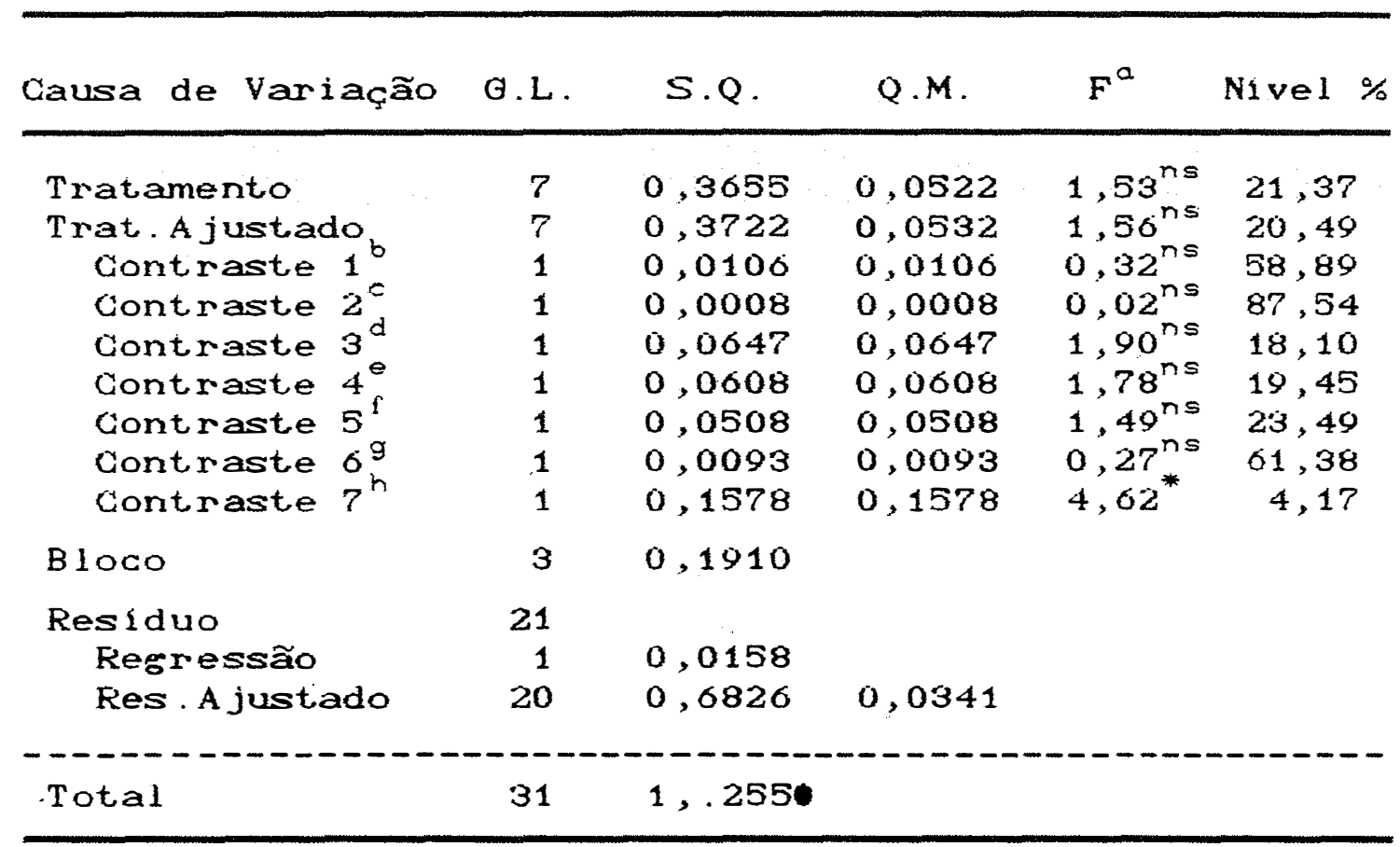

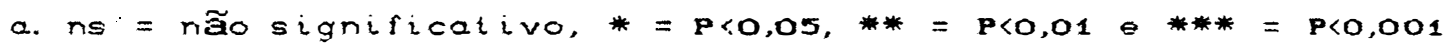

b. $\mathbf{T}_{1}+\mathbf{T} 2+\mathbf{T} \mathbf{3}+\mathbf{T} 4+\mathbf{T}+\mathrm{T} \sigma$ versus $\mathbf{T} 7+\mathbf{T}$

c. $\mathrm{T} 7$ versus $\mathbf{T B}$

d. $\mathbf{T} 1+\mathrm{T}_{2}+\mathrm{T} 3+\mathrm{T} 4$ versus $\mathrm{T} 5+\mathrm{T} \sigma$

e. $\mathbf{T} 1+\mathbf{T}_{2}$ versus $\mathbf{r} \mathbf{3}+\mathbf{T}_{4}$

r. $\mathbf{T} 1+\mathrm{T}_{3}$ versus $\mathbf{T} 2+\mathrm{T}_{4}$

g. $\mathbf{T} 1+\mathbf{T} 4$ versus $\mathbf{T} 2+\mathrm{T} 3 \mathrm{I}$

h. TS versus To

Coeficiente de variação $=28.03 \%$

Média geral ajustada $=0,365$ 
130.

Apêndice 25 - Analise de variáncia do consumo diário de ração (CDR) de 21 a 49 dias, com ajuste por covariancia para o peso médio inicial aos 21 dias.

\begin{tabular}{|c|c|c|c|c|c|}
\hline Causa de Variação & G.L. & $S . Q$ & $\mathrm{Q} \cdot \mathrm{M}$. & $F^{\alpha}$ & Nivel $\%$ \\
\hline Tratamento & 7 & 0,0009 & 0,0096 & $3,10^{*}$ & 2,19 \\
\hline Trat. A justado & 7 & 0,0689 & 0,0098 & $3,19^{*}$ & 1,93 \\
\hline Contraste $1^{b}$ & 1 & 0,0083 & 0,0083 & $2,08^{n s}$ & 11,39 \\
\hline Contraste $2^{c}$ & 1 & 0,0006 & 0,0006 & $0,20^{n s}$ & 60,30 \\
\hline Contraste $3^{d}$ & 1 & 0,0352 & 0,0352 & $11,43^{* *}$ & 0,32 \\
\hline Contraste $4^{\circ}$ & 1 & 0,0044 & 0,0044 & $1,42^{n s}$ & 24,68 \\
\hline Contraste $5^{f}$ & 1 & 0,0096 & 0,0090 & $3,11^{n s}$ & 8,90 \\
\hline Contraste $6^{9}$ & 1 & 0,0013 & 0,0013 & $0,44^{n s}$ & $52,36^{\circ}$ \\
\hline Contraste $T^{h}$ & 1 & 0,0094 & 0,0094 & $3,04^{n s}$ & 9,32 \\
\hline Bloco & 3 & 0,0061 & & & \\
\hline Residuc & 21 & & & & \\
\hline Regressão & 1 & 0,0072 & & & \\
\hline Res. A justado & 20 & 0,0617 & 0,0031 & & \\
\hline $\begin{array}{l}\text { Total } \\
\text { Total }\end{array}$ & 31 & 0,1418 & & & \\
\hline
\end{tabular}

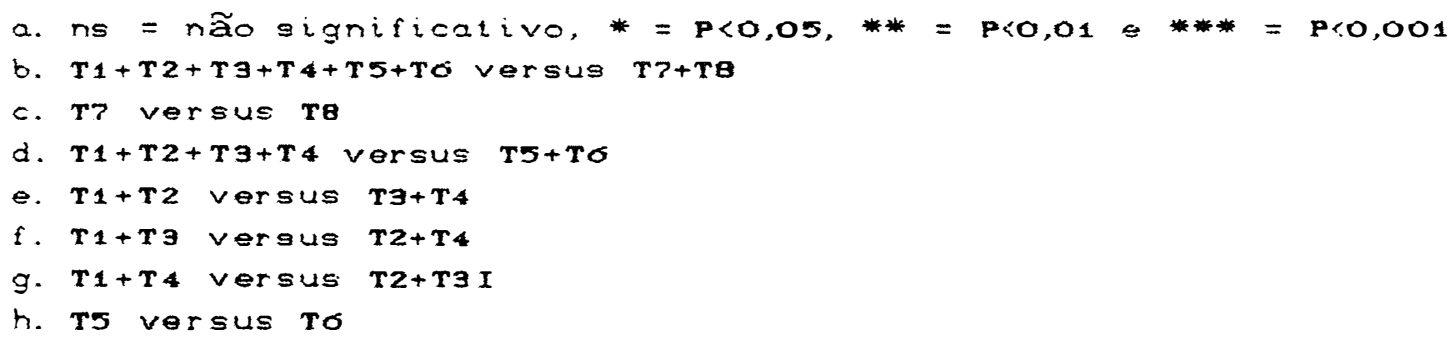


Apêndice 26 - Análise de variancia do consumo diário de ração (CDR) de 49 a 61 dias, com ajuste por covariância para o peso médio inicial aos 49 dias.

\begin{tabular}{|c|c|c|c|c|c|}
\hline Causa de Variação & U.L. & $S . Q$ & $Q \cdot M$. & $F^{a}$ & Nivel $\%$ \\
\hline Tratamento & 7 & 0,1314 & 0,0187 & $1,53^{\text {ns }}$ & 21,37 \\
\hline Trat. A justado & 7 & 0,1319 & 0,0188 & $1,54^{n s}$ & 21,20 \\
\hline Contraste $1^{b}$ & 1 & 0,0095 & 0,0095 & $0,77^{\text {ns }}$ & 60,60 \\
\hline Contraste $2^{\circ}$ & 1 & 0,0646 & 0,0640 & $5,20^{*}$ & 3,10 \\
\hline Contraste $3^{d}$ & 1 & 0,0028 & 0,0028 & $0,22^{n s}$ & 64,51 \\
\hline Cont raste $4^{\ominus}$ & 1 & 0,0194 & 0,0194 & $1,59^{n s}$ & 22,04 \\
\hline Cont raste $5^{f}$ & 1 & 0.0193 & 0,0193 & $1,57^{n s}$ & 22,22 \\
\hline Contraste $6^{g}$ & 1 & 0,0014 & 0,0014 & $0,11^{\text {ns }}$ & 74,03 \\
\hline Contraste $7^{\mathrm{h}}$ & 1 & 0,0068 & 0,0068 & $0,55^{n s}$ & 52,69 \\
\hline Bloco & 3 & 0,1430 & & & \\
\hline Residuo & 21 & & & & \\
\hline Regressão & 1 & 0,0053 & & & \\
\hline Res. A justado & 20 & 0,2455 & 0,0123 & & \\
\hline & & & & & \\
\hline Total & 31 & 0,5253 & & & \\
\hline
\end{tabular}

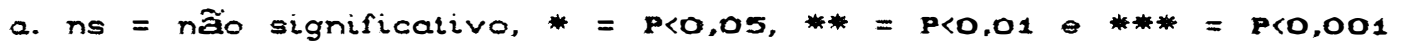

b. T1+T2+T3+T4+T5+To versus Tr+TB

c. $\mathbf{T} 7$ versus $\mathbf{T B}$

d. T1+T2+T3+T4 versus $\mathrm{T} 5+\mathrm{TO}$

e. $\mathbf{T} 1+\mathbf{T 2}$ versus $\mathbf{T} 3+\mathbf{T} 4$

f. T1+T3 versus $\mathbf{T 2}+\mathbf{T}_{4}$

g. $\mathbf{T} 1+\mathbf{T} 4$ versus $\mathbf{T} 2+\mathbf{T} \mathbf{9}$

h. T5 versus ro

Coeficiente de variação $=11,91 \%$

Média seral ajustada $=0,131$ 
Apéndice 27 - Análise de variáncia do consumo diário de ração (CDR) de 21 a 01 dias, com ajuste por covariância para o peso médio inicial aos 21 dias.

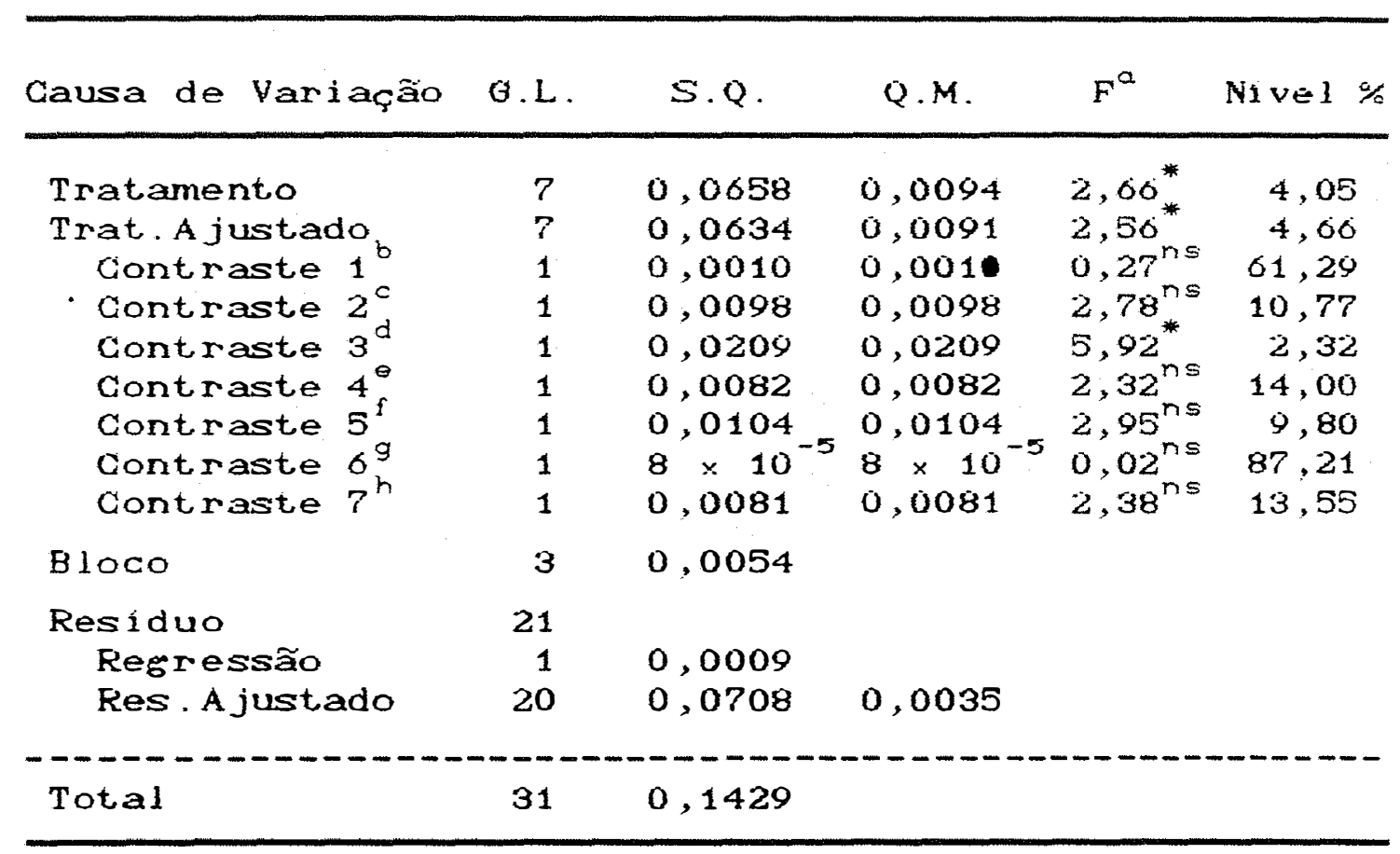

a. $n s=$ ñ̃o significativo, $=\mathbf{P}<0,05, *=\mathbf{P}<0,01=\mathbf{P}<0,001$

b. T1 T $2+T 3+T 4+T 5+T 0$ versus $T 7+T B$

c. $T ?$ versus $\mathbf{T B}$

d. $\mathrm{T}_{1}+\mathrm{T}_{2}+\mathrm{T}_{3}+\mathrm{T}_{4}$ versus $\mathrm{T} 5+\mathrm{To}$

e. $T_{1}+T_{2}$ versis $T_{3}+T_{4}$

f. $T_{1}+T_{3}$ versus $T_{2}+T_{4}$

5. $\mathbf{T}_{1}+\mathbf{T}_{4}$ versus $\mathbf{T} 2+\mathbf{T} \mathbf{I}$

h. rs versus ro

Coeficiente de variação $=12,05 \%$

Média seral ajustada $=0,494$ 
Apêndice 28 - Análise da variáncia para estudo do efeito de tratamento e periodo de amostragem na flutuação de Ig sérica em leitð̌s, no periodo de 1 a 61 dias.

\begin{tabular}{|c|c|c|c|c|c|}
\hline Causa de Variação & G.L. & S.Q. & Q.M. & $F^{a}$ & Nivel $\%$ \\
\hline Tratamento & 3 & 0,0220 & 0,0073 & $3,17^{n s}$ & 7,77 \\
\hline $\begin{array}{l}\text { Contraste } 1^{b} \\
\text { Contraste } 2^{c} \\
\text { Contraste } 3^{d}\end{array}$ & $\begin{array}{l}1 \\
1 \\
1\end{array}$ & $\begin{array}{l}0,0134 \\
0,0011 \\
0,0076\end{array}$ & $\begin{array}{l}0,0134 \\
0,0011 \\
0,0076\end{array}$ & $\begin{array}{l}5,77^{*} \\
0,46^{n s} \\
3,28^{n s}\end{array}$ & $\begin{array}{r}3,82 \\
51,92 \\
10,11\end{array}$ \\
\hline B loco & 3 & 0,0065 & & & \\
\hline Residuo (A) & 9 & 0,0208 & 0,0023 & & \\
\hline Parce las & 15 & 0,0493 & & & \\
\hline Goletas & $\dot{0}$ & 0,1011 & 0,0100 & $20,89^{* *}$ & 0,001 \\
\hline $\begin{array}{l}\text { Interação } \\
\text { Trat. } x \text { Co } 1 .\end{array}$ & 18 & 0,0094 & 0,0005 & $0,65^{n s}$ & 84,75 \\
\hline Residuo (B) & 72 & 0,0581 & 0,0008 & & \\
\hline Total & 111 & 0,2180 & & & \\
\hline
\end{tabular}

a. ns = não significativo, * = P<0,05, ** $=\mathbf{P}<0,01 \theta_{* * *}^{*} \mathbf{P}<0,001$

b. T3+T4+To versus $\mathbf{T B}$

c. $\mathbf{T} 9+\mathbf{T} 4$ versus To

d. T3 versus $\mathbf{T} 4$

Coeficiente de variação $(A)=0,951 \%$

Coeficiente de variação $(B)=10,859 \%$ 
Apendice 29 - Análise da variáncla para estudo do efelto do periodo de amostragem, de 1 a 28 dias, na flutuação de Is sérica em leitões.

\begin{tabular}{|c|c|c|c|c|c|}
\hline Causa de Variação & G.L. & $S \cdot Q$ & Q.M. & $F^{a}$ & Nivel $\%$ \\
\hline Tratamento & 3 & 0,0207 & 0,0069 & $2,83^{n s}$ & 9,84 \\
\hline $\begin{array}{l}\text { Contraste } 1^{b} \\
\text { Contraste } 2^{c} \\
\text { Contraste } 3^{d}\end{array}$ & $\begin{array}{l}1 \\
1 \\
1\end{array}$ & $\begin{array}{l}0,0124 \\
0,0010 \\
0,0073\end{array}$ & $\begin{array}{l}0,0124 \\
0,0010 \\
0,0073\end{array}$ & $\begin{array}{l}5,09^{*} \\
0,41^{n s} \\
2,99^{n s}\end{array}$ & $\begin{array}{r}4,86 \\
54,37 \\
11,53\end{array}$ \\
\hline B loco & 3 & 0,0068 & & & \\
\hline Residuo (A) & 9 & 0,0219 & 0,0024 & & \\
\hline Parce 1 as & 15 & 0,0494 & & & \\
\hline Coletas & 4 & 0,0850 & 0,0212 & $27,71^{* * *}$ & 0,001 \\
\hline $\begin{array}{l}\text { Interação } \\
\text { Trat. } x \text { Col. }\end{array}$ & 12 & 0,0062 & 0,0005 & $0,67^{n s}$ & $76, .79$ \\
\hline Residuo (B) & 48 & 0,0368 & 0,0008 & & \\
\hline Total & 79 & 0,1775 & & & \\
\hline
\end{tabular}

a. $n s=$ não significativo, $*=\mathbf{P}<0,05, * *=P<0,01 * \theta_{*}^{*}=0,001$

b. $\mathbf{T} 9+\mathrm{T} 4+\mathrm{T} \sigma$ versus $\mathrm{TB}$

c. $\mathbf{T} 9+\mathbf{T} 4$ versus $\mathrm{To}$

d. T9 versus $\mathrm{T} 4$

Coeficiente de variação $(A)=8,412 \%$

Coeficiente de variação $(B)=10,553 \%$ 
Apêndice 30 - Análise da variäncia para estudo do efeite do periodo de amostragem de 28 a 61 dias ná flutuação de Ió sérica em leitôes.

\begin{tabular}{|c|c|c|c|c|c|}
\hline Causa de Variação & G.L. & $S . Q$. & $Q . M$. & $F^{a}$ & Nivel $\%$ \\
\hline Tratamerito & 3 & 0,0049 & 0,0016 & $1,33^{n s}$ & 32,39 \\
\hline $\begin{array}{l}\text { Contraste } 1^{b} \\
\text { Contraste } 2^{c} \\
\text { Contraste } 3^{d}\end{array}$ & $\begin{array}{l}1 \\
1 \\
1\end{array}$ & $\begin{array}{l}0,0029 \\
0,00002 \\
0,0019\end{array}$ & $\begin{array}{l}0,0029 \\
0,00002 \\
0,0019\end{array}$ & $\begin{array}{l}2,42^{n s} \\
0,01^{n s} \\
1,56^{n s}\end{array}$ & $\begin{array}{l}15,22 \\
89,08 \\
24,20\end{array}$ \\
\hline Bloco & 3 & 0,0000 & & & \\
\hline Residuo (A) & 9 & 0,0110 & 0,0012 & & \\
\hline Parce 1 as & 15 & 0,0105 & & & \\
\hline Coletas & 2 & 0,0355 & 0,0178 & $25,0.4^{* * *}$ & 0,002 \\
\hline $\begin{array}{l}\text { Interação } \\
\text { Trat x col }\end{array}$ & 0 & 0,0024 & 0,0004 & $0,58^{n s}$ & 74,16 \\
\hline Residuo (B) & 24 & 0,0166 & 0,0007 & & \\
\hline Total & 47 & 0,0716 & & & \\
\hline
\end{tabular}

a. ns = não significativo, * = P<0,05, ** $=\mathbf{P}<0,01$ e***=P<0,001

b. $\mathbf{T 3 + T 4 + T \sigma}$ versus $\mathbf{T B}$

c. $\mathrm{T} 3+\mathrm{T} 4$ versus $\mathrm{T} \sigma$

d. T3 versus $T 4$

Coeficiente de variação $(\mathrm{A})=8.232 \%$

Coeficiente de variação $(B)=10,743 \%$ 